\title{
A practical review on the measurement tools for cellular adhesion force
}

Rita Ungai-Salánki ${ }^{1,2,3} *$, Beatrix Peter ${ }^{2}$, Tamás Gerecsei ${ }^{1,2}$, Norbert Orgovan ${ }^{1,2}$, Robert Horvath ${ }^{2}$, Bálint Szabó ${ }^{1,2}$

${ }^{1}$ Department of Biological Physics, Eötvös University, Pázmány Péter sétány 1A, Budapest, H-1117 Hungary

${ }^{2}$ Nanobiosensorics Group, Research Centre for Natural Sciences, Institute for Technical Physics and Materials Science, Konkoly Thege M. út 29-33. 1121, Budapest, Hungary

${ }^{3}$ CellSorter Company for Innovations, Erdőalja út 174, Budapest, H-1037 Hungary

\begin{abstract}
Cell-cell and cell-matrix adhesions are fundamental in all multicellular organisms. They play a key role in cellular growth, differentiation, pattern formation and migration. Cell-cell adhesion is substantial in the immune response, pathogen-host interactions, and tumor development. The success of tissue engineering and stem cell implantations strongly depends on the fine control of live cell adhesion on the surface of natural or biomimetic scaffolds. Therefore, the quantitative and precise measurement of the adhesion strength of living cells is critical, not only in basic research but in modern technologies, too. Several techniques have been developed or are under development to quantify cell adhesion. All of them have their pros and cons, which has to be carefully considered before the experiments and interpretation of the recorded data. Current review provides a guide to choose the appropriate technique to answer a specific biological question or to complete a biomedical test by measuring cell adhesion.
\end{abstract}

Keywords (maximum 6): cell adhesion, single cell, adhesion force, force measurement techniques

\section{Commonly used units:}

Shear stress: $1 \mathrm{dyn} / \mathrm{cm}^{2}=0.1 \mathrm{~Pa}, 1 \mathrm{pN} / \mu \mathrm{m}^{2}=1 \mathrm{~Pa}$

Force: 1 dyn $=10^{-5} \mathrm{~N}$ 


\section{Abbreviations:}

AFM: atomic force microscopy

BFP: biomembrane force probe

CTFM: cell traction force microscopy

DDS: dimethyldichlorosilane

ECM: extracellular matrix

FluidFM: fluidic force microscopy

FRET: fluorescence resonance energy transfer

GETS: genetically encoded molecular tension sensor

ICAM-1: intercellular adhesion molecule-1

MAT: micropipette aspiration technique

NTA: nitrilotriacetic acid

OT: optical tweezers

PA: polyacrilamide

PCR: polymerase chain reaction

PDMS: poly-dymethylsiloxane

PLL-g-PEG: poly (L-lysine)-grafted-poly(ethylene glycol)

PMMA: polymethylmethacrylate

PPFC: parallel plate flow chamber

QCM: quartz crystal microbalance

QPD: quadrant photodiode

RBC: red blood cell 
RFC: radial flow chamber

RGD: arginyl-glycyl-aspartic acid

RPM: revolutions per minute

SAM: self-assembled monolayer

$S_{c}$ : critical separation pressure

SCFS: single cell force spectroscopy

SPR: surface plasmon resonance

SPT: step-pressure technique

* Corresponding author: salanki.rita@gmail.com 


\section{Table of contents}

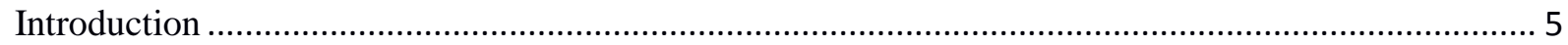

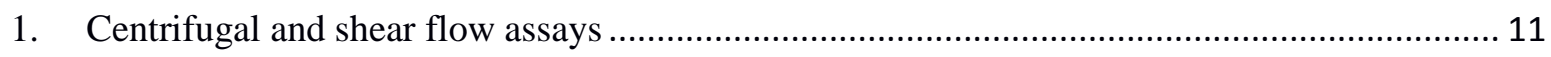

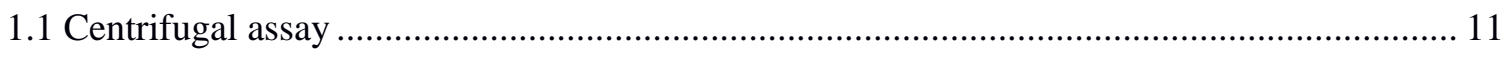

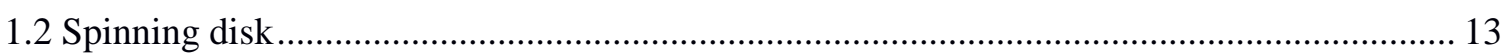

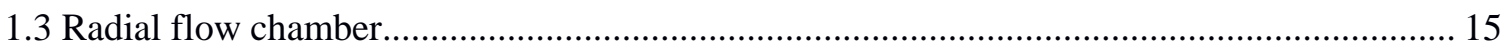

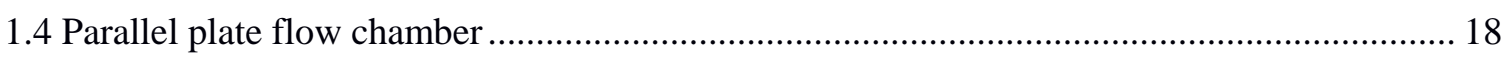

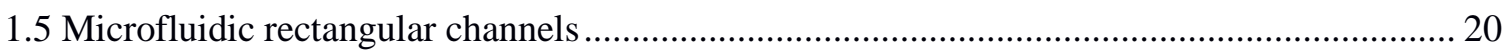

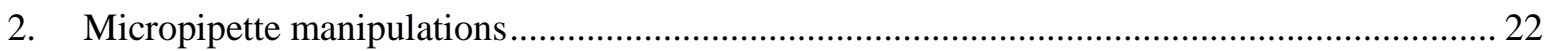

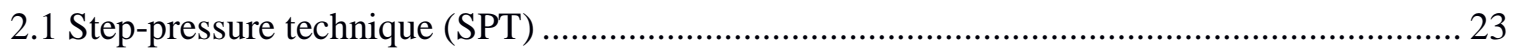

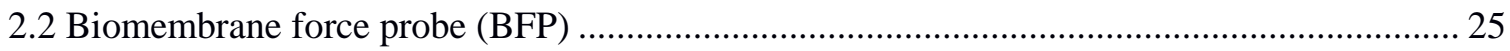

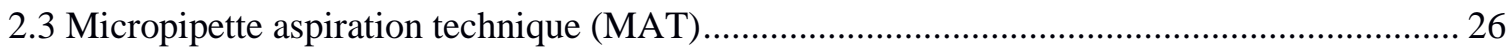

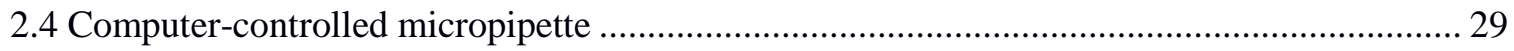

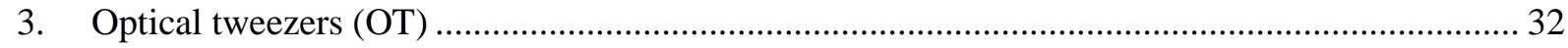

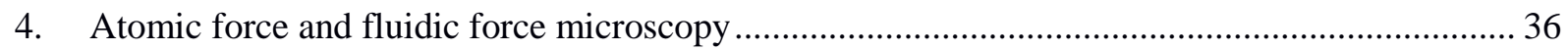

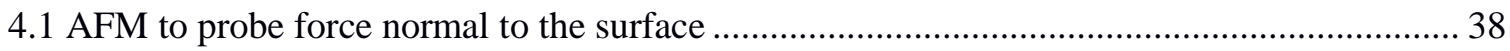

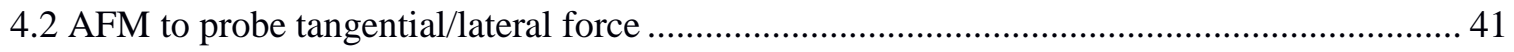

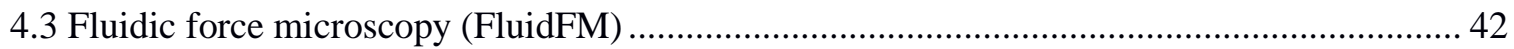

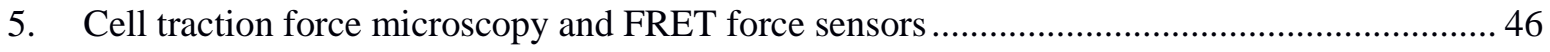

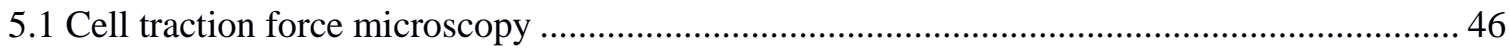

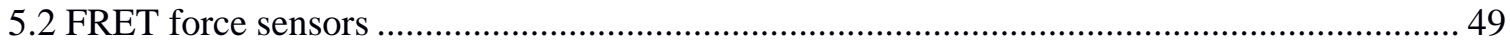

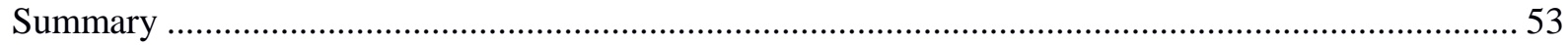

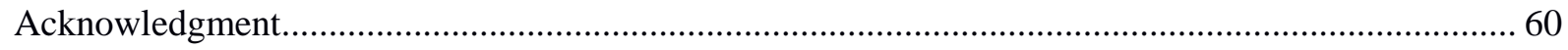

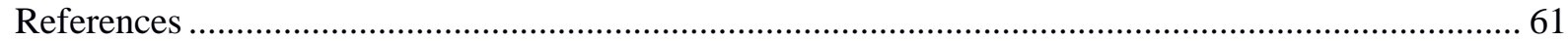




\section{Introduction}

Cell adhesion [1] is the ability of a cell to stick to another cell or to the extracellular matrix (ECM). Most mammalian cell types are anchorage-dependent and attach firmly to their environment [2]. Cell adhesion mediated by cell surface receptor molecules, such as integrins [3],[4], cadherins [5],[6], selectins, and members of the immunoglobulin superfamily is a fundamental phenomenon [7] vital for both multi and single cellular organisms (Fig.1). Upon binding their extracellular ligand (such as fibronectin, vitronectin or collagen), integrin molecules cluster to form focal adhesions, complexes containing structural and signalling molecules crucial to the adhesion process [8]. Best-characterized adhesions are the 'classical' focal adhesions (also termed focal contacts) and variants including fibrillar adhesions, focal complexes and podosomes [9]. Focal adhesions mediate strong adhesion to the substrate, and they anchor bundles of actin microfilaments through a plaque that consists of many different proteins [9]. Fibrillar adhesions are associated with ECM fibrils. Focal complexes are present mainly at the edges of the lamellipodium. Podosomes contain typical focal contact proteins such as vinculin and paxillin and they are found in various malignant cells [9].

Communication between cells and the ECM is critically influenced by the mechanical properties of cell surface receptor-ligand interactions. Integrin binding forces were measured in intact cells by atomic force microscopy (AFM) for several RGD containing (Arg-Gly-Asp) ligands and ranged from 32 to $97 \mathrm{pN}$. The context of the RGD sequence within the ligand protein has considerable influence upon the final binding force [10]. Lee and Marchant reported that the binding force of the single molecular interaction between the RGD-ligand and the integrin was $90 \mathrm{pN}[11]$.

Mechanical forces are central to the functioning of living cells. Cell adhesion is known to be closely related to the actin cytoskeleton, of which organization is crucial in determining the structural and mechanical properties of cells. While significant experimental progress has been made to measure the forces generated by cells, interpretation of these experimental results poses a challenge. Measurements can only be fully interpreted in the light of biophysical models of cell mechanics. However, even a single cell is so complex that theoretical models can usually describe only a few aspects of its behaviour, e.g., contractility considering some cellular components such as stress fibers [12]. In cell cultures on stiff substrates, the actin cytoskeleton tends to be organized into stress fibers, bundles of actin filaments tensed by myosin II molecular motors. Stress fibers usually end in focal adhesions: integrin-based adhesion contacts at the cell 
membrane. The coupling between mechanics and biochemistry should also be considered in the model [13]. Some models are inspired by architecture like the the so-called tensegrity model [14] of the cytoskeleton [15]. Adhesion-dependent cells sense the mechanical properties of their environment by mechanotransductory processes through focal adhesions. Simplified models applying springs replacing the complex architecture and biochemistry of the cell can be successful to explain certain experimental results [16] A two-spring model [17] showed that the stiffer the environment, the stronger force is built up at focal adhesions by molecular motors interacting with the actin filaments.

Dynamic control of cell adhesion is indispensable to the developing embryo [7], to the immune system [18], and critical in the metastasis of tumors [19],[20],[21] or in the successful implantation of a prosthesis. In case of inflammation, several successive steps of the immune cell adhesion are known [18]. Although the molecular background of this particular process is partially explored there is a lot more to discover about cellular adhesion in general.

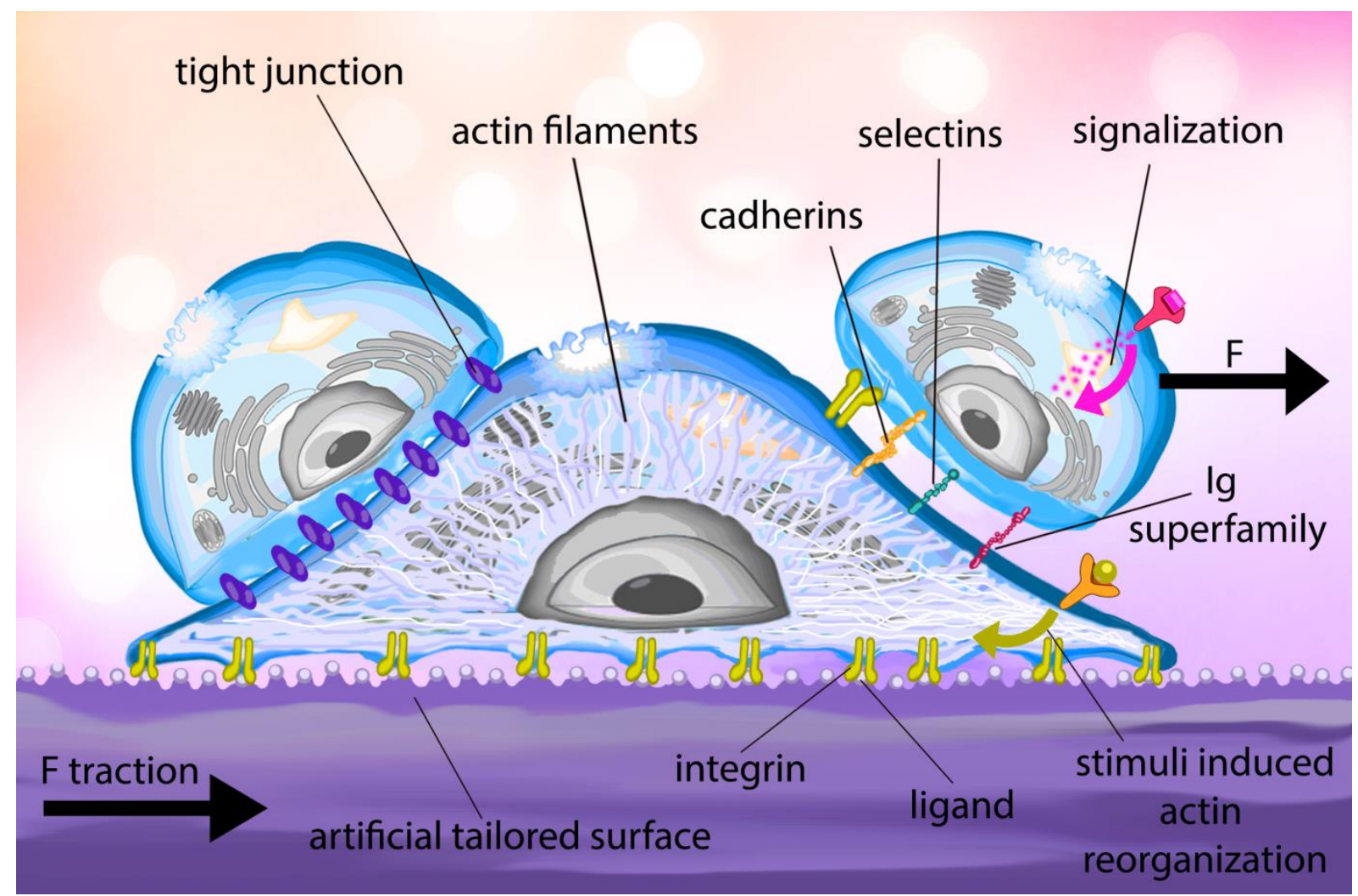

Fig.1 Basic processes of cell adhesion: the artificially tailored surface contains ligands that bind to the integrin receptors found in the membrane of cells. Throughout the process of adhesion, the actin filament structure of the cell is reorganized and a traction force is generated in the substrate. The cytoskeletal reorganization is also regulated by external stimuli. After adhesion to the surface, the cell can interact with other cells through membrane 
proteins such as cadherins, selectins and members of the Ig superfamily. In tissues a variety of multiprotein complexes called cell junctions (e.g. tight junctions), can form between cells to promote intercellular communication and mechanical stability.

In vitro environments to study cell adhesion. Both biochemical techniques for tailoring large surfaces on the molecular level and methods capable of the high-throughput high sensitivity measurement of cell adhesion [22],[23],[24],[25] have emerged in the past few years. Appropriate masking (blocking) of the surface area not covered by specific biomolecules has central importance to get rid of non-specific adhesion of cells on, e.g., glass or plastic substrates. For this the protein repellent PLL-g-PEG synthetic polymer [26],[27],[28],[29] proved to be exceptionally useful. Grafting the RGD motif of three amino acid residues into the PEG side chains results in a passivated surface designed for cell adhesion exclusively via RGD-binding cell surface receptors [30],[31]. For investigating cell adhesion mediated by functional proteins (engineered with a His tag) NTA-functionalized PLL-g-PEG [32] offers a versatile possibility. Recently, a 10-fold increase in surface passivation efficiency could be achieved over PEG using the Tween-20 molecule on DDS surfaces [33].

Recent studies demonstrated that a compact and oriented flagellin protein layer - mimicking the surface of bacterial flagellum - has excellent cell repellent capabilities[34],[35],[36],[37]. By genetically engineering the molecule, peptid sequences (for example RGD motif) can be incorporated into this cell repellent layer facilitating receptor specific cellular adhesion. Flagellins can be produced in bacteria and are available in large quantities, opening up an interesting new direction in developing biomimetic engineered surfaces.

Tools to measure cell adherence. A number of different techniques can be applied to measure cell adhesion force [38] (Fig.2). Many of them, including the simple washing assay [39], the spinning disk technique [40] and flow chambers [41] are based on the hydrodynamic shear flow removing cells from the surface [42]. However, these techniques do not enable single cell targeting, and cell shape has a strong impact on the shear force making difficult to calculate the exact adhesion force. Furthermore, only weakly adhered cells can be probed due to the technically limited magnitude of shear stress. 


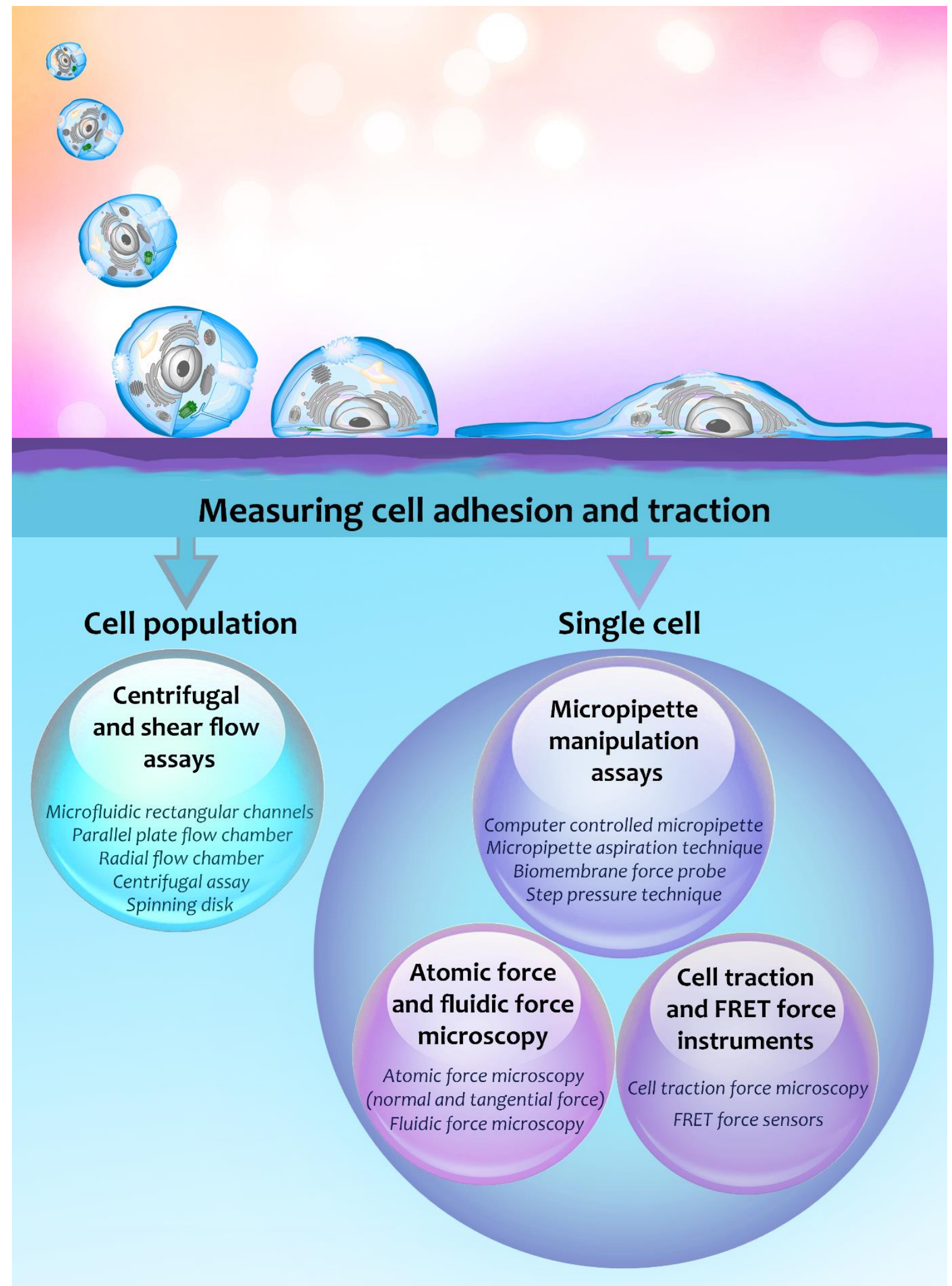

Fig.2 Classification of cell adhesion measurement techniques. Population based assays rely on removing the cells from a surface by hydrodynamic sheer flow. The adhesion force can be calculated from the applied flow rate, 
however the extracted value depends on other factors as well, such as cell shape. Single cell based techniques can be further divided into categories depending on their principle of operation. Micropipette manipulation assays apply a glass micropipette to aspirate cells from the surface and calculate the adhesion force using hydrodynamic simulations. Atomic force microscopy combined with chemical tip modifications or a nanofluidic channel can also be used to investigate cell adhesion. Other methods include FRET sensors that apply genetically modified cells expressing proteins whose fluorescent signal depends on mechanical tension, as well as force traction measurements capable of detecting forces generated in the substrate by the adhering cell. Data originating from population and single cell based methods differ fundamentally as the population methods are measuring an average over thousands of cells, while single cell measurements can explore differences in heterogeneous populations.

To directly probe the adhesion force of single cells, cytodetachment with an AFM tip [2], [43],[44] or micropipette aspiration [45],[46],[47] can be chosen as a tool. Both of them are inherently low throughput methods: typically 5-10 cells can be measured in a day. A modified AFM applying vacuum on cells with a fluidic micro-channel (FluidFM) [48] eliminates the painful AFM cantilever chemistry. In a FluidFM, a cantilever can be used for about 10 cells, thus throughput is increased by a factor of 10 compared to conventional AFM. Additionally, the force range is enlarged to reach the $\mu \mathrm{N}$ regime.

Automated glass micropipette equipped onto an inverted microscope can probe the adhesion force of single cells with a relatively high throughput: hundreds of cells can be measured in a $\sim 30$ min experiment. Cells can be automatically selected on the basis of computer vision. Single viable cells picked up by the micropipette can be further analyzed by, e.g., DNA/RNA sequencing. Hydrodynamic lifting force acting on cells positioned under the micropipette is calculated from off-line computer simulations.

Cell traction force microscopy (CTFM) [49] enables the force (mechanical stress) field generated by single cells on an elastic substrate to be reconstructed with a resolution of $\sim 1-10$ $\mu \mathrm{m}$. Since its introduction in 1996, CTFM has undergone impressive developments. However, the computation of the traction filed is challenging and strongly depends on the mathematical model applied. Thus the derivation of the cellular traction force is not straightforward.

Molecular force sensors [50] inside cells based on Förster resonance energy transfer (FRET) offer a brilliant tool for the high resolution mapping of force distribution inside live cells. The FRET sensor is incorporated into a specific protein of the cytoskeleton in a transgene cell type. The extra gene is constructed to express the two fluorescent proteins separated by an elastic 
linker region. When the elastic linker region expands as a spring pulled by a mechanic force, the distance of the fluorescent proteins, i.e., the FRET donor and acceptor changes, and can be detected in the fluorescent signal.

An interesting alternative to measure cellular adhesion with high sensitivity and high temporal resolution is the application of novel evanescent field based optical biosensors [22],[51],[52],[53]. Here, the biosensor signal is directly proportional to the cell-substratum contact area and also correlates with the number of biomolecules in the adhesion contact zone, presumably proportional to the strength of adhesion [51]. These label free methods can readily monitor not only the strength but the real-time kinetics of cellular adhesion [22],[54]. But they are indirect, and thus the calculation of the adhesion force is not straightforward; an open problem not yet solved. However, they have clear advantages when the biomolecular adsorption, prior to the adhesion of living cells, has to be also recorded in a single experiment $[55]$.

Surface plasmon resonance (SPR) microscopy can be used as an alternative method for visualizing and quantifying cell/substrate contacts of living cells [56]. SPR, the most wellknown evanescent field based optical method is usually used in in biosensor setups to monitor molecular interactions such as receptor/ligand binding in real time. However, SPR has not been demonstrated to measure adhesion forces directly or indirectly.

Quartz crystal microbalance (QCM) with dissipation [57],[58],[59] is a simple, high-resolution mass sensing technique allowing in situ real-time measurements of mass and viscoelasticity changes through the resonance frequency (f) and energy dissipation (D) during the cell adhesion process. It can monitor morphological and cytoskeletal changes of surface adherent cells in a non-invasive way [60]. Nevertheless, QCM cannot measure the adhesion force.

Sensitive monitoring of the adhesion process of a large number of single cells on surfaces precisely decorated with biomolecules is expected to produce information on ligand binding, receptor function and signaling pathways with a quality and magnitude used to be unattainable with former cell adhesion assays. Exploring the many faces of molecular scale (nanoscale) direct physical interactions between cells and their environment is a fundamental goal of biophysics, which now seems to be accessible. 
Below we divided the available techniques into two categories: population methods and singlecell approaches (Fig.2). Whereas population methods provide cell adhesion data with good statistics, targeting and probing single cells offer a direct and more sensitive measurement of cell adhesion [61]. Inherent heterogeneity of cell populations can be also explored by single cell measurements.

\section{Centrifugal and shear flow assays}

Adhesion force of a cell on a substrate can be probed with simple cell detachment assays like centrifugal or shear flow chambers based on a centrifugal or hydrodynamic shear force to remove weakly attached cells from the substrate [62],[63]. While the applied centrifugal force can act both in a direction normal and parallel to the surface onto cells are attached, shear force is always parallel to the surface. Cells adhered to the surface weaker than the centrifugal or shear force are removed. The exact value of the shear force is difficult to control and therefore ill-defined [2] as it sensitively depends on parameters such as cell size and shape [43]. Although simple washing assays allow the identification of key adhesion components, they provide only qualitative adhesion data. Hydrodynamic shear flow assay applying a well-controlled shear stress to adherent cells is the most common way to quantify cell adhesion. Most widespread methods are the spinning disk, radial flow chambers and parallel plate flow chambers (Table 1).

\subsection{Centrifugal assay}

Cell adhesion strength can be determined using a centrifugal cell detachment assay as described by Chu et. al.(1994) [64] introduced earlier by McClay et al. (1981) [65] and Lotz et al. (1989) [66]. Centrifugal assay employs standard laboratory centrifuges to apply forces on cells adhered to a substrate. Briefly, substrates for cell adhesion are glued to the bottom of a 24-well plate. At the end of the incubation, the wells are filled with medium and covered with sealing tape to avoid medium loss and air bubbles. Then the plates are inverted and spun in a swing-bucket centrifuge for 10 minutes (at $25^{\circ} \mathrm{C}, 800 \mathrm{~g}$ ) [31],[67] (Fig.3). After centrifugation, the number of cells is quantified manually. This assay measures the average response of a cell population and typically examines the fraction of cells that remain adhered to the surface after centrifugation. 


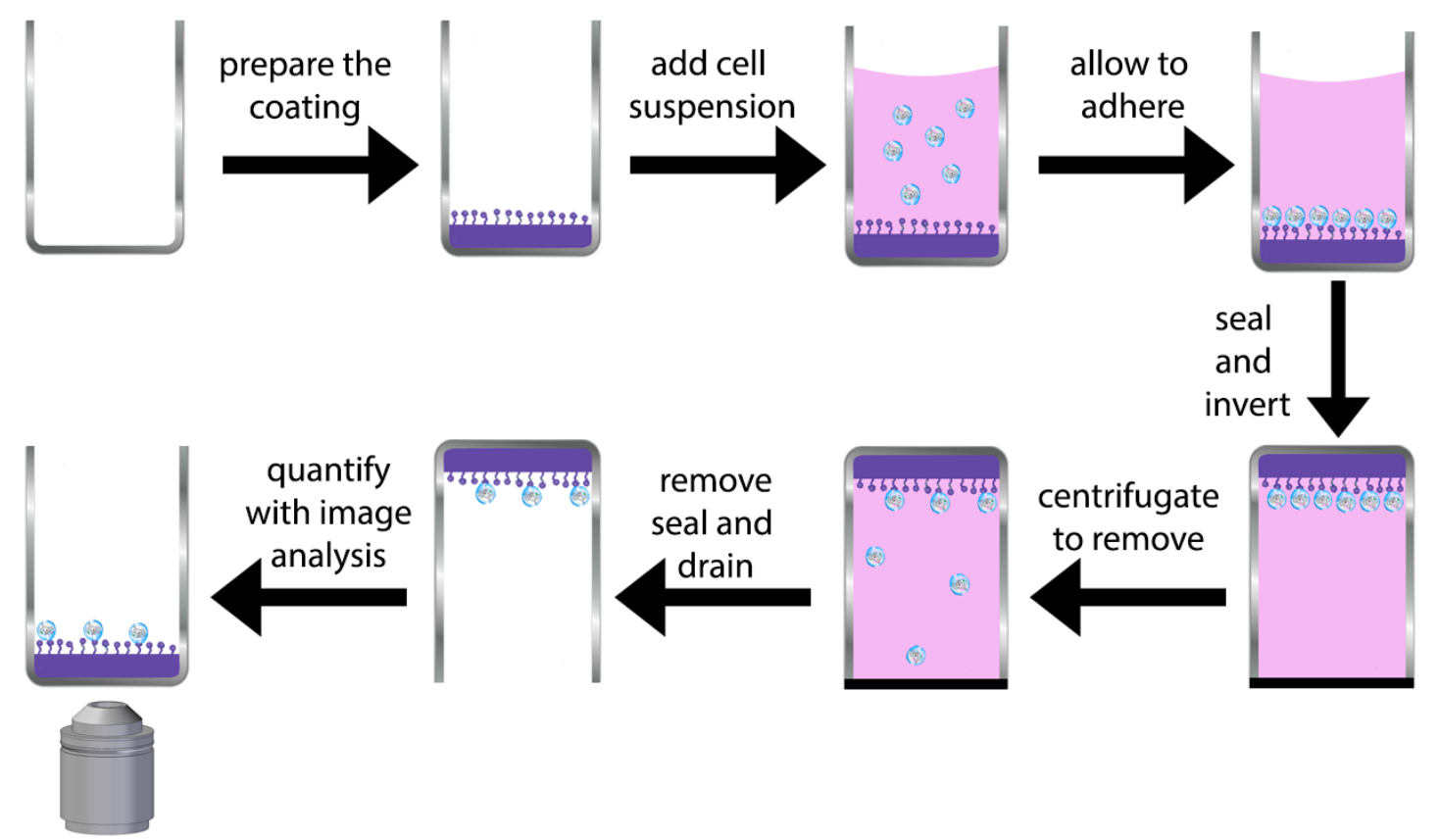

Fig. 3 Steps followed in the centrifugal assay in the study of Chu and co-workers [64]. A substrate for cell-adhesion is prepared in a 24-well plate then filled with cell suspension. Cells are let to adhere in an incubator, then the well is sealed airtight and placed in a centrifuge with an opposite orientation. As the centrifugation begins, the cells are affected by a detaching force in the range of 1-100 $\mathrm{nN}$ depending on the used acceleration. The fraction of cells detached from the surface can be quantified using optical microscopy. The presented method is simple and cost-efficient, however the force range is limited by the centrifuge's properties. Even with ultracentrifuges reaching 100,000 $\mathrm{g}$ in acceleration. Only weakly adhering cells can be studied. Furthermore, the cell shape is altered significantly by the high acceleration endured by the cells during centrifugation.

\section{a. Number of cells in an experiment}

Typical cell number is $10^{5}$ cell [68].

\section{b. Typical range of centrifugal force}

This assay applies controlled detachment forces to a large population of adherent cells [69].To determine the adhesion strength, the number of cells is quantified before and after applying the centrifugal force [42]. The force in the centrifuge is calculated as follows:

$$
\mathbf{F}=\mathbf{G} \times V_{\text {cell }} \times(\rho \text { cell- } \rho \text { medium }),
$$


where $F$ is the force exerted on the cell, $G$ is the centrifugal acceleration, $V_{\text {cell }}$ is the cell volume, $\rho_{\text {cell }}$ is the density of the cell (typically $1.07 \mathrm{~g} / \mathrm{cm}^{3}$ ), $\rho_{\text {medium }}$ is the density of the medium (typically $1.00 \mathrm{~g} / \mathrm{cm}^{3}$ ) [31],[42]. Typical $\mathrm{G}$ values fall in the range of 20-1,000g and the forces on an individual cell is $1-2,000 \mathrm{pN}$ When using an ultracentrifuge, adhesion force can be measured up to $100 \mathrm{nN}$ [70],[71] with a maximum acceleration of 110,000 g. However, before cells detach due to such a high acceleration, cell shape changes dramatically similarly to shear force induced shape alteration.

\section{c. Experiment duration}

The duration of load application in centrifuge tests typically range from 5 to $10 \mathrm{~min}$ [31],[42], [69],[72].

\section{d. Advantages}

Simplicity. It does not require specialized equipment: the method is widely accessible [42].

\section{e. Disadvantages}

Normally restricted to the investigation of weakly-adhered cells [42].

\section{f. Main applications}

Adhesion of MC3T3-E1 cells on self-assembled monolayers (SAMs) as a function of fibronectin density [42],[69] . Cell-cell adhesion mediated by E-cadherin [68]. Cell adhesion to specific RGD-modified substrates over a wide range of forces [31]. Strength of bacteriumreceptor interactions [73].

\subsection{Spinning disk}

The apparatus applies a disk spinning in a large volume of fluid. The cell adhesive surface is mounted onto a rotating circular stage, which produces a fluid flow in the chamber [74] . Fluid flow over the cells on the disk creates a detachment force [75], which is calculated from the properties of the buffer and the rotational speed (Fig.4). At the axis of rotation the detachment force is zero and it increases linearly with the distance from the axis. This fewer cells will 
remain near the edge of the disk than closer to the axis. After spinning, the remaining adherent cells are fixed, stained, and counted.

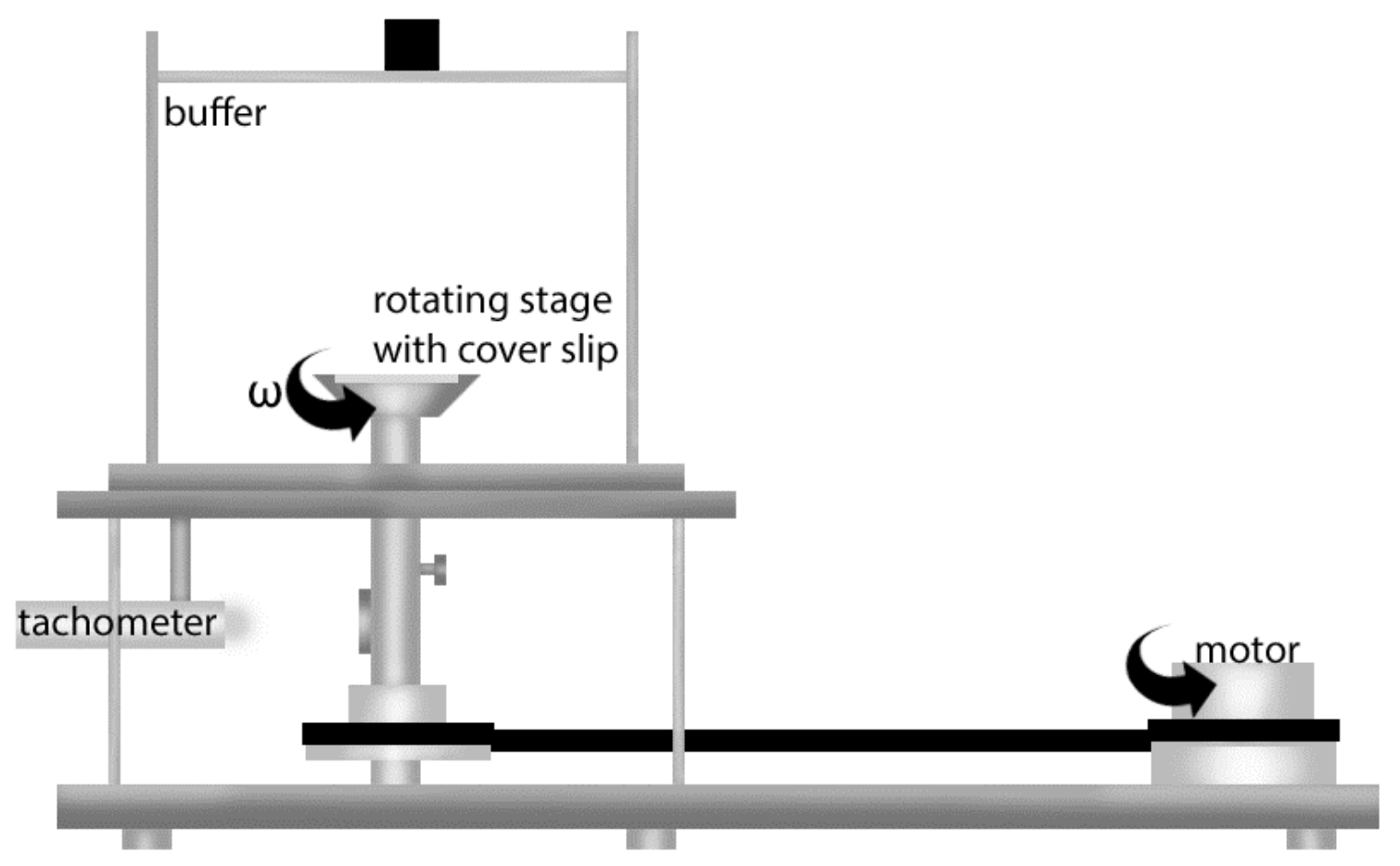

Fig.4 Spinning disk arrangement in the experiment of Wertheim et al [74]. Cells are allowed to settle onto a fibronectin-coated matrix atop the stage. As the stage is rotated, the spinning stage inside the fluid is generating a sheer flow on the surface. The stress caused by this flow is linearly increasing from the center of the disk to the edge, causing a number of cells to detach in the function of distance from the center. The distribution of cells that remain on the stage after spinning can be quantified by optical microscopy. Because of the linearly changing shear stress on the surface, a range of forces can be studied at the same time. The disadvantage of this method is common in all shear flow based techniques namely the dependence of the measured detachment force on cell shape. This particular construction also makes it impossible to optically observe the cells during measurement.

a. Number of cells in an experiment

400 cells $/ \mathrm{mm}^{2}[76]$ are uniformly seeded onto coverslips.

b. Typical range of shear stress

Detachment force is proportional to the hydrodynamic wall shear stress, $\tau$ (shear force/area) 


$$
\tau=0.800 \mathbf{r} \sqrt{\rho \mu \omega^{3}}
$$

where $r$ is the radial position from the disk center, $\rho$ and $\mu$ are fluid density and viscosity, respectively and $\omega$ is the angular speed ( $\mathrm{rad} / \mathrm{s})$. Typical frequency range: 500-3000 RPM [42].The shear force increases linearly with the radius from the center of the disk, thus it can generate a wide range of forces at the same time.

A value of $200 \mathrm{~Pa}$ shear stress was reported [77]. The range of detachment forces is $\left(0-10 \mathrm{~Pa}^{2}\right)$ [74].

\section{c. Experiment duration}

Disks were usually spun for 5- 10 min at constant speed [76],[77].

\section{d. Advantages}

The key advantage of the method is the shear stress increases linearly with the radial position on the disk allowing a wide range of forces to be applied at the same time [42],[74]. Spinning disk method can generate high shear stresses and detach relatively strongly-adhered cells.

\section{e. Disadvantages}

Hydrodynamic shear force depends on cell shape [75]. It is not compatible with simultaneous microscopic imaging [61].

\section{f. Main applications}

Binding strength between cells and Fn-coated micropattern islands [40]. Modell system: erythroleukemia cell line, expressing a single fibronectin receptor, integrin $\alpha 5 \beta 1$. Cell detachment profile and mean detachment force measurements [75],[77]. Bacterial spore adhesion [78].

\subsection{Radial flow chamber}

In the axisymmetric flow geometry of radial flow chambers (RFC), a wide range of radially dependent shear stress is applied to the adherent cells in a single experiment [79]. A design of 
RFC by Stone (1993) [80] employs a chamber on an inverted microscope, allowing in situ observation of adherent cells exposed to shear stress. The surface is pre-incubated, then the cells are introduced into the RFC by a syringe and allowed to adhere to the surfaces for a given time ( 30-60 min), prior to applying the shear. Fluid [79],[81] flows radially between the surface with the cells and a glass slide at a constant volumetric flow rate for $\sim 5 \mathrm{~min}$ (Fig.5). The chamber has a $200 \mu \mathrm{m}$ gap between the surfaces. Cells are removed, where the shear force exceeds the adhesive force of cells [80] .

The mean velocity of the fluid and hence the shear stress, decreases with increasing radial position, $r$. For the radial flow, the Reynolds number is inversely proportional to radial position:

$$
\operatorname{Re}=\frac{2 \rho Q}{\pi \mu r}
$$

where $Q$ is the flow rate, $\rho$ and $\mu$ are the density and viscosity of the fluid, respectively. To ensure laminar flow, the critical upper limit to $R e$ is 2000 .

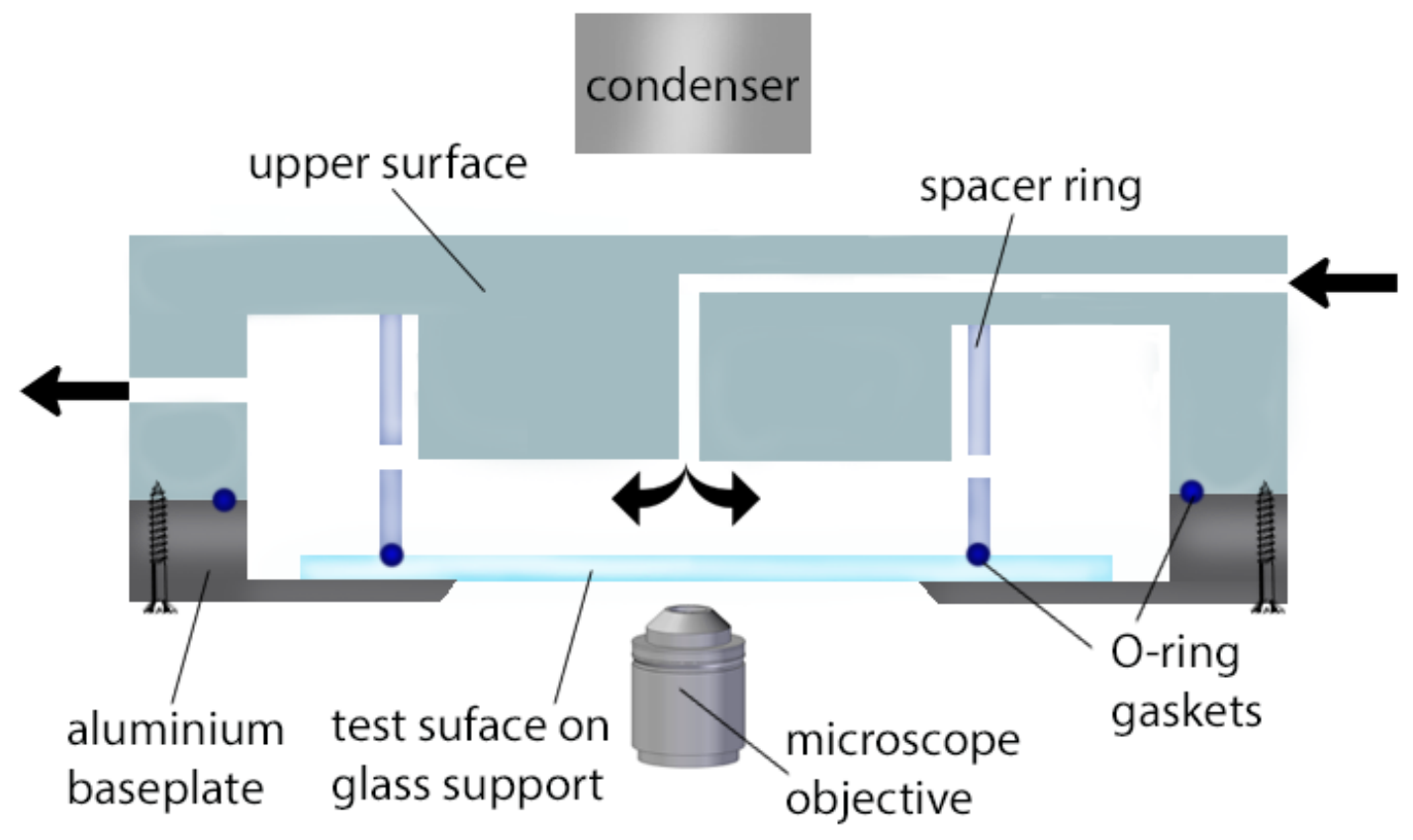

Fig.5 Schematic illustration of the radial flow chamber based on the publication of Goldstein et al. (1998) [81]. The cells are seeded on the glass support, exposed to a laminar flow coming from above. The flow rate determines the shear stress on the cells up to the point where the flow would become turbulent. Much like in the spinning disk case, the stress is linearly changing with the position relative to the center of the dish but in this case the maximum 
falls to the center and decreases as we approach to the edge. This construction can be directly mounted on an inverted microscope thus enabling the optical monitoring of the detachment process.

a. Number of cells in an experiment

$10^{5}$ cells / $\mathrm{ml}$ added to a 60-mm-diameter dish. Seeding density: 40 cells/ $\mathrm{mm}^{2}$ [79],[80].

Cells are plated at an approximate density of $10.25 \times 10^{4}$ cells $/ \mathrm{mL}\left(\sim 8.34 \times 10^{4}\right.$ cells $/ \mathrm{cm}^{2}$, $\sim 2.64 \times 10^{6}$ cells/surface) [82].

\section{b. Typical range of shear stress}

Cells were allowed to attach to fibronectin-coated substrates for $30 \mathrm{~min}$ and then subjected to a spatially dependent range of shear stress for $5 \mathrm{~min}\left(28-220 \mathrm{dyn} / \mathrm{cm}^{2}\right)$ [83].

After 75 to $90 \mathrm{~min}$, at a shear stress of 350 dynes $/ \mathrm{cm}^{2}$, more than $50 \%$ of the spread cells are detached from the surface. Cells with higher spreading areas stay longer at the glass surface [84].

\section{c. Experiment duration}

Cells are incubated for 30-60 min. Shear stress is applied for $~ 5 \min$ [79],[81],[83],[84].

\section{d. Advantages}

Broad range of the shear stress simultaneously [81]. If the RFC is mounted on an automated microscope, in situ observation of cell detachment can be monitored under the hydrodynamic shear stress [79],[83]. It is allowed the application of uniform stress fields to cells while enabling visualization of the cells via microscopy [61].

\section{e. Disadvantages}

These chambers are unable to generate stresses high enough to detach well-spread cells under laminar flow conditions [61]. Shear stress limitations due to the upper limit of Reynolds number to avoid turbulence [81]. Complex fluidics needed [85].

\section{f. Main applications}

In situ detachment of 3T3 murine fibroblasts from substrata of SAMs of dodecanethiolate [79],[81] and fibronectin. Cell deformations (elongation) after applying the shear stress [79],[86]. Adhesive nature of the modified substrates [82]. Bacterial adhesion experiments [87]. 


\subsection{Parallel plate flow chamber}

In the parallel plate flow chamber (PPFC) (Fig.6) the flow is precisely defined to produce a uniform shear stress [84],[88],[89],[90]. Shear stress $\tau\left(\right.$ dyne $\left./ \mathrm{cm}^{2}\right)$ is calculated from the following equation:

$$
\tau=6 Q \mu / w h^{2}
$$

where $Q$ is the volumetric flow rate $\left(\mathrm{cm}^{3} / \mathrm{s}\right), \mu$ is the viscosity of the medium, $w$ is the width of the chamber and $\mathrm{h}$ is the height of the chamber. Usually, a peristaltic pump is used to adjust the required flow rate [90].
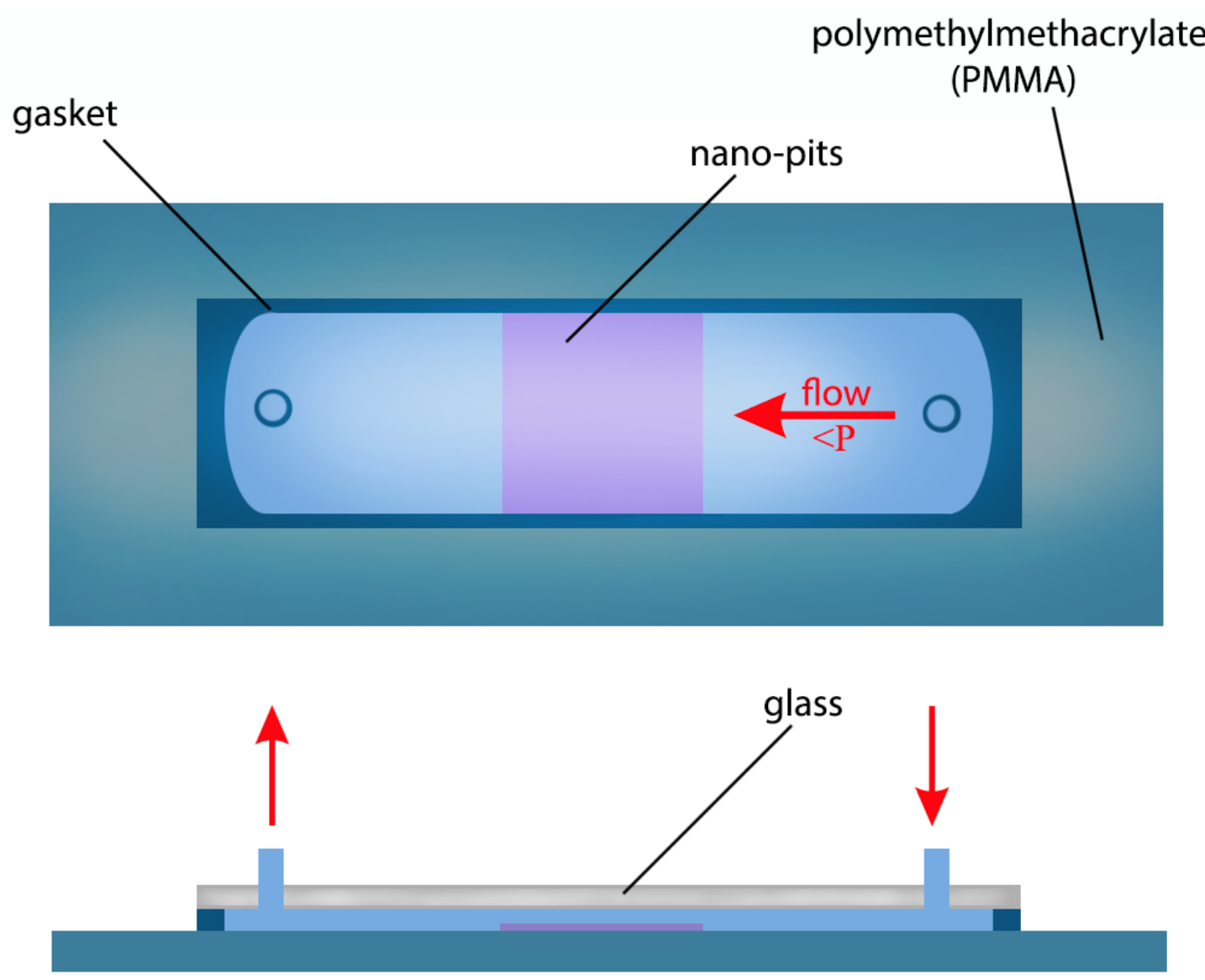
Fig.6 Schematic illustrations of a parallel plate flow chamber used to characterize the effect of nanotopology on cell adhesion based on the publication of Martines et al.(2004) [91]. A polymethylmethacrylate (PMMA) sample (turquoise) was patterned with $100 \mathrm{~nm}$ nanopits, then a glass slide (light blue) was attached to it with a thermoplasitc gasket (dark blue) in between. The channels in the PMMA were designed to create a laminar flow within the chamber. The inlet and outlet for the solution is provided by circular holes in the glass slide on the top of the device. The adhesion strength can be measured by monitoring the attached cell's density as a function of the flow in the channels. The authors have successfully shown the adhesion reducing property of the nanopatterned surface topology.

\section{a. Number of cells in an experiment}

This technique can be used to monitor the removal of a population of cells from a surface. Seeding concentration: $10^{4}-10^{6}$ cells $/ \mathrm{ml}$ resulting in $100-1,000$ cells $/ \mathrm{mm}^{2}$ [88],[91],[92]. However, normally only few hundred cells are analyzed.

\section{b. Typical range of shear stress}

1-25 Pa [89],[90],[92],[93]. Cells can be exposed to either a single shear stress or incremental shear stress levels [89]. Also the effect of increasing pulsatile flow on cell adhesion can be monitored [93].

\section{c. Experiment duration}

Time elapsing after seeding cells on the surface, and before applying the shear stress: 1-24 hours [88]. Duration of shear stress can be several hours [90]. In the incremental shear studies shear stress can be increased in the time scale of minutes (4-15 $\mathrm{min}$ ) [89],[93]. In ref [92] cells were exposed to a range of shear stress levels each applied for only $2-10 \mathrm{sec}$.

\section{d. Advantages}

Parallel plate flow chamber can be utilized widely due to its simple well-characterized flow regime [89]. The chamber can be mounted onto a microscope, thus the behavior of the cells as a response to the shear stress can be observed in situ. Parallel flow chambers can provide a precisely controlled, uniform shear stress with dynamic, well-defined shear regulation [94]. In this chamber the motion of a sphere can be easily calculated. Cell trajectories, speed and adhesion process can be monitored [91]. It is a frequently applied design because of its simplicity. It can be employed on a broad range of surfaces, such as silicone rubber, dental enamel and metals [95]. 


\section{e. Disadvantages}

The most parallel plate flow chamber have a height $>200 \mu \mathrm{m}$ [61]. This sets a practical limit on the shear stress value considering the normally available range of flow rate or overpressure.

\section{f. Main applications}

Channels can be used to determine the strength of adhesion of fibroblast cells to various substrates, with different wettabilities [89]. Cell retention, morphology and migration as a function of flow rate and the influence of adhesion time were also studied [88]. Endothelial cell adherence onto polymer surfaces with different hydrophilicity [90]. Investigation of nanopatterned surfaces [91]. Development of flow circuits, in which the behavior of cells can be continuously monitored on a microscope [88]. The flow circuit usually consists of three parts: a flow loop, a heating system, and an image analysis component [88],[89]. Adhesion of bacterial and yeast strains to a PEO (Poly(ethylene oxide))-brush covalently attached to glass [96]. Measurement of the attachment and detachment rates of Escherichia coli to and from a glass surface [97]. Nonspecific surface attachment of hydrophobic yeast cells [98].

\subsection{Microfluidic rectangular channels}

This technique is similar to the parallel plate flow chamber, but the key advantage is the small characteristic dimension of the flow channel $(\mathrm{h}<100 \mu \mathrm{m})$ that allows substantially higher shear stresses to be generated under laminar flow conditions [61] (Fig.7). The channels can be readily mounted onto a microscope, and thus cell detachment can be monitored in situ. The device is usually constructed from PDMS, because it is quick and simple to use, cheap, transparent, and biocompatible [99],[100]. 


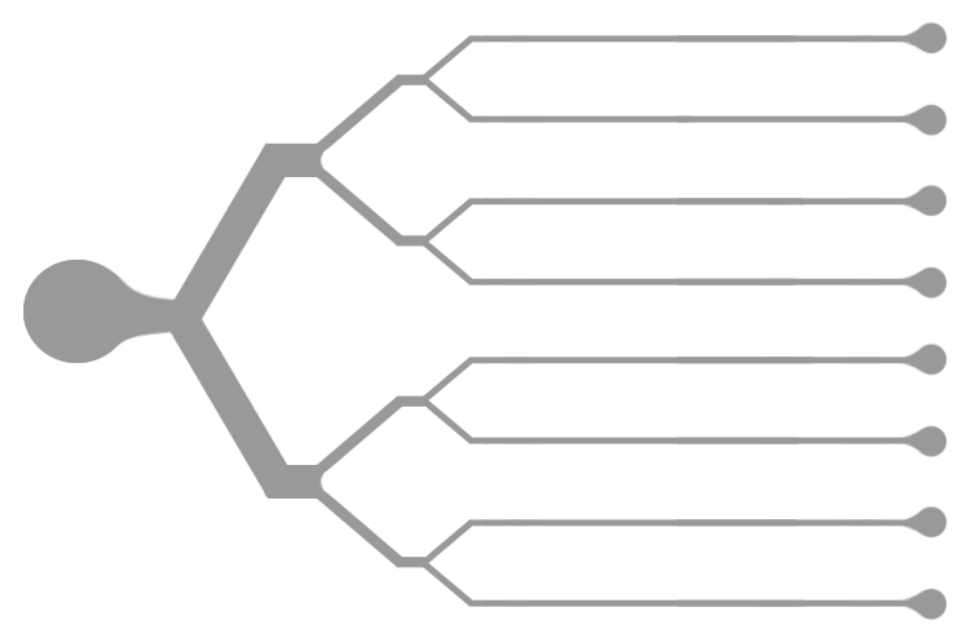

Fig.7 Parallel microfluidic shear device pattern, consisting of eight microchannels used in the study of Young and co-workers [101]. The flow is directed into the device through the common inlet on the left. The $516 \mu \mathrm{m}$ wide and $59 \mu \mathrm{m}$ high channels are designed to ensure identical flow in all branches. The main advantage of this arrangement is the parallelization of measurements: a fraction of the channels were coated with proteins, while others were used as control during the same experiment. Cell spreading and attachment can be monitored by optical observation of the channels by an inverted microscope.

\section{a. Number of cells in an experiment}

Cell suspension density: $10^{6}-10^{7}$ cells/ ml Number of analyzed cells: $100-1,000$. Usually $1-$ 10 microscopic fields of view with 10-100 cells/ field of view [61],[100],[101],[102].

\section{b. Typical range of shear stress}

50-200 $\mathrm{Pa}$ [61]. When the shear stress is time dependent, its rate is usually in the $1-10 \mathrm{~Pa} / \mathrm{sec}$ range [61]. 1 - $20 \mathrm{~Pa}[101]$.

\section{c. Experiment duration}

Typical experiment duration: 10-15 min [61]. Adhesion strength of cells was investigated in 12 min, while shear stress level was increased step by step in 4 min intervals in ref [101].

\section{d. Advantages}

This method offers a wide range of forces and relatively high-throughput. The experimental setup is simple, and it can be integrated with other microanalytic modules. Using time-lapse 
microscopy, cell detachment can be monitored in situ. The microfluidic device offers advantages with its small dimensions and ensures laminar flow even at high fluid velocities. The small channel height $(\mathrm{h}<100 \mu \mathrm{m})$ enables higher shear stress than the similar parallel plate flow channel. Thus also the strongly adherent cells (cannot be studied in most conventional assays) can be investigated in microfluidic rectangular channels [61]. The device is usually fabricated from poly-dymethylsiloxane (PDMS) bonded to glass using the rapid technique of soft photolithography [100]. The technique has small sample consumption and it provides a stable and well characterized flow [101],[102]. A parallel microfluidic network of the channels permits the parallel analysis of multiple samples or conditions [101].

\section{e. Disadvantages}

At the micron scale, channel deformation effect becomes important and must be quantified for predictable assay performance [99]. Cell morphology is affected by the flow: cells become elongated due to the applied shear stress. It shows that the flow can significantly alter the cytoskeleton several minutes before cells detach from the surface [101]. This "side-effect" needs to be thoroughly considered when evaluating experimental results.

\section{f. Main applications}

Measurement of the adhesion strength of well-spread cells on different surfaces [61]. Investigating the adhesion difference between normal and cancerous epithelial cells on nanostructured polymer surfaces. Adherence of vascular and valvular endothelial cells on different extracellular matrix proteins (fibronectin, collagen I) [101]. Observation of bacterial adhesion [103],[104].

\section{Micropipette manipulations}

The use of micropipette manipulation studies can be traced back to Mitchison and Swann (1954). They first developed and applied a micropipette-based elastimeter to determine the membrane elastic modulus and internal pressure of the unfertilized sea urchin eggs. The method can measure the deformation of a single cell attached to the tip of a micropipette by a precisely controlled vacuum in the micropipette [104]. Ten years later, Rand and Burton (1964) refined this method. They measured the stiffness of the erythrocyte (RBC) membrane and the pressure inside the cell [105],[106]. In the 1970-80s, the micropipette manipulation method was further 
improved and a number of studies applied it to explore the mechanics of RBCs, white blood cells, endothelial cells, lipid vesicles, and liposomes. These studies imposed either a local force or a suction underpressure on individual cells or liposome surface. In the 1990s, the technique was extended to studies including tumor cell metastasis and the kinetics of cell-cell contact interactions [46]. The common approach is to quantify the adhesion strength by imposing tension to rupture the adhesive contact between two opposite faces. An increasing force is employed to measure the magnitude of the rupture force. Alternatively, a constant force is applied to determine the adhesion lifetime [46].

Micropipette manipulation techniques are summarized in Table 2.

\subsection{Step-pressure technique (SPT)}

Sung et al. (1986) developed the first micropipette based technique, which was used to quantify cell adhesion strength [47]. The system consists of a cylindrical glass micropipette with an internal diameter of a few $\mu \mathrm{m}$-s and a manometer to control the pressure inside the micropipette with a resolution of $0,01 \mathrm{pN} / \mu \mathrm{m}^{2}$ [43],[107],[108]. One cell is tightly held by micropipette 1 with high suction vacuum, while the second is held by micropipette 2 with lower suction force. First, the two cells are brought into contact, so they can adhere to each other. Then micropipette 2 is pulled away (Fig.8). The suction vacuum in micropipette 2 is increased until the cells are separated from each other. The minimum suction vacuum which leads to the separation of the cells is the critical separation pressure $\left(\mathrm{S}_{\mathrm{c}}\right)$. One of the cells can be replaced with a protein coated substrate to determine the cell- substrate adhesion strength [46].

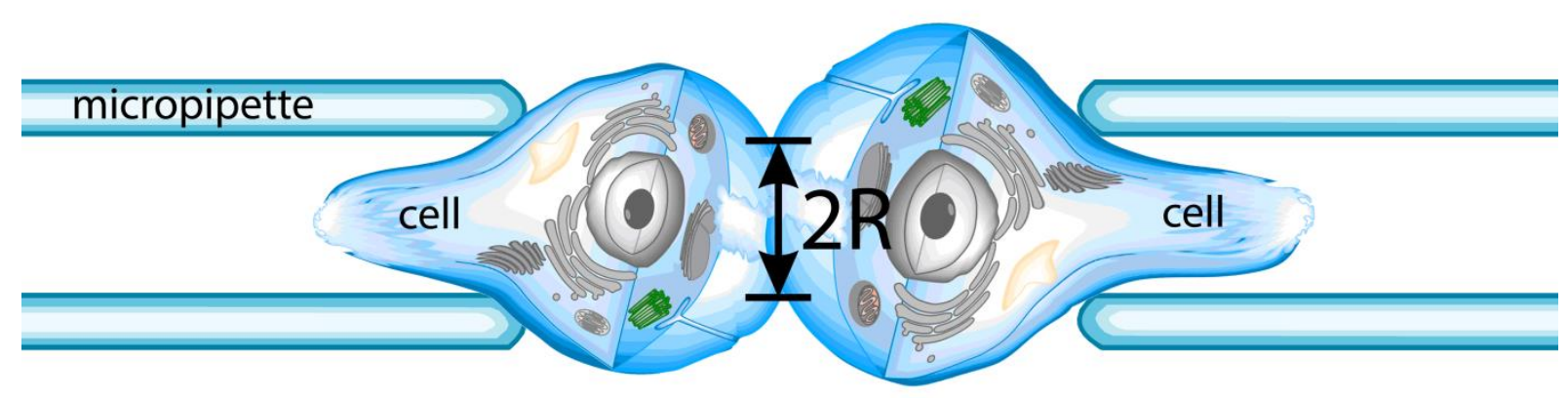


Fig.8 Schematic illustration of step-pressure technique (based on the publication of Shao et al.) [46]. Two micropipettes each with a cell sucked into their tips are facing each other as the cell's surfaces are pushed together. After a certain adhesion time, the cell on the left is pulled away. If the moving cell slips out of the micropipette, the suction force was smaller than the adhesion force between the cells. By increasing the suction force, an upper estimate can be determined for the inter-cell adhesion force and energy. This method was the first to be used to measure single cell adhesion by glass micropipettes. This technique allows a precise control of cell contact area and time, however the nonspecific adhesion between the glass tips and the cell membrane must be eliminated. Another disadvantage of any similar method is the dependence of the measured adhesion properties on the speed of the separation of the micropipette tips.

\section{a. Number of cells in an experiment}

$\sim 10$ pairs of cells [109].

\section{b. Typical force range}

The applied vacuum is in the 10-100 Pa range [109],[110]. $\mathrm{Sc}=1,5 \mathrm{nN} / \mu \mathrm{m}^{2}$, However, it is difficult to measure the exact contact area between the cells. Separation force is in the $1-10 \mathrm{mN}$ range [46],[47].

\section{c. Experiment duration}

Cells are brought into contact for $\sim 10 \mathrm{sec}$ [110]. In ref [47] Sung et al. measured the adhesion force between two cells for $120 \mathrm{~min}$. The first measurement started at $12 \mathrm{~min}$ and subsequent measurements were taken in every $10 \mathrm{~min}$.

\section{d. Advantages}

Enables the measurement of the adhesion force between two similar or different single cells in vitro [47]. Cell-cell contact area and contact time can be controlled [46],[110].

\section{e. Disadvantages}

Nonspecific adhesion between the cell and pipette wall has to be much weaker than the overall adhesion to the other cell or to the substrate [46]. Low throughput, manual measurement. 


\section{f. Main applications}

Enables the real time observation of two cells assembling and then losing the contact zone in between them. Cell adhesion force can be measured directly [46].

\subsection{Biomembrane force probe (BFP)}

Evans et al. (1995) described a simple apparatus and procedure for probing weak forces at biological surfaces [111]. The technique applies a force transducer (these are cell-sized membrane capsules such as a vesicle, liposome or an erythrocyte) which is held by a micropipette with a suction force while a micro-bead is attached to the force transducer [46],[47]. The microscopic bead is glued biochemically to the transducer. The bead is coated with the protein of interest in order to interact with the cell (Fig.9). Pulling or pushing force applied to the bead result in membrane deformation of the force transducer [46].

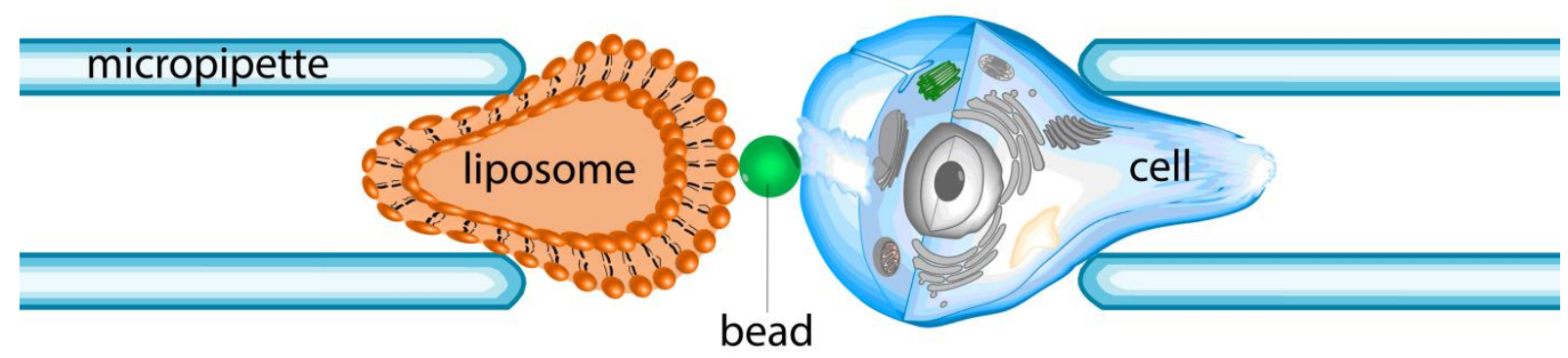

Fig.9 Schematic illustration of biomembrane force probe (Based on the publication of Shao et al. [46]). A liposome is sucked into a micropipette that is biochemically glued to a latex bead. By pushing or pulling the liposome, a force can be exerted on the bond between the cell and the bead. As the latter can be coated with a protein of interest, receptor-ligand bonds can be studied under a controllable loading rate and force. Using this arrangement Evans et al. showed that the rupture force of a ligand-receptor bond depends on the speed at which the force is applied.

a. Number of cells in an experiment

1 cell/experiment. 


\section{b. Typical force range}

Evans et al. (1998) employed two modes of BFP; vertical and horizontal modes. Vertical mode was used to test weak bonds under slow loading, when the force was $0.2-0.5 \mathrm{pN}$; while the horizontal mode was utilized to study stronger bonds under fast loading (1-10 pN) [112]. The transducer sensitivity is tuned to measure forces from 0.01 to $1,000 \mathrm{pN}$ with a range of loading rates from $0.1 \mathrm{pN} / \mathrm{s}$ to $100,000 \mathrm{pN} / \mathrm{s}$. Evans et al. have shown that, rupture force of a receptorligand bond depends on the loading rate of the force, i.e., how fast the bond is pulled [46],[113], [114],[115],[116],[117],[118].

\section{c. Experiment duration}

No information.

\section{d. Advantages}

The loading rate of the force is adjustable [46]. The interference to the cell can be minimized. Gentle measurement minimally altering the cytoskeleton. Weak adhesive bonds can be readily detected. Sensitivity of the technique enables the detection of local activation of cytoskeletal structures [111]. The method has sub-pN force and nanometer scale displacement resolution [46].

\section{e. Disadvantages}

The resolution of probe movement is not as good as in AFM [111].

\section{f. Main applications}

It allows the quantification of single molecular bonds [38]. Receptor-ligand binding [46].

\subsection{Micropipette aspiration technique (MAT)}


The technique was developed by Shao and Hochmuth (1996). They applied the method to measure the magnitude of $\mathrm{pN}$ forces [46],[107]. Their aim was to create a simple method based on micropipette suction, allowing the measurement of detachment force of one cell from another cell or a solid surface [107] (Fig.10).
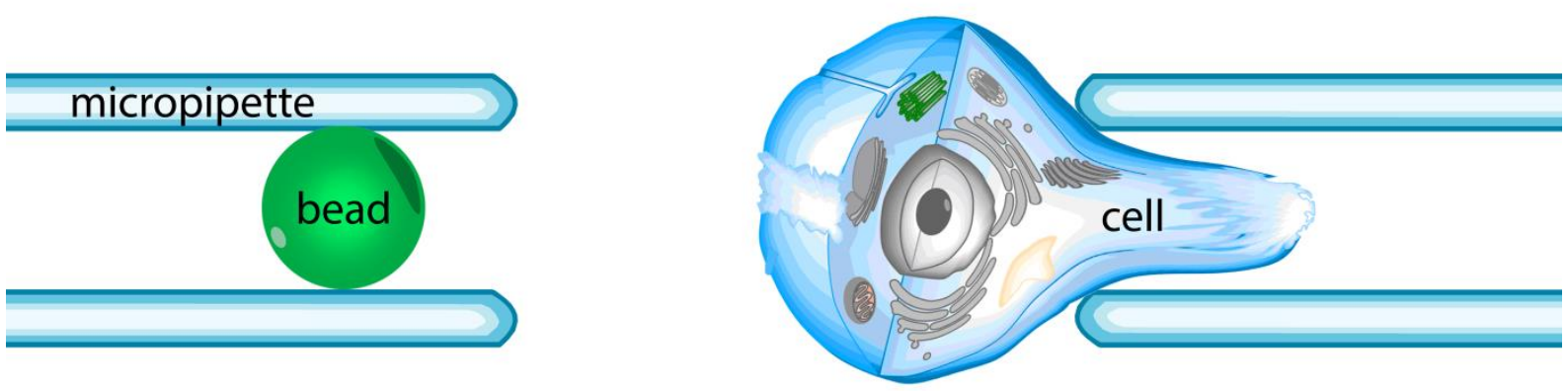

Fig.10 Schematic illustration of micropipette aspiration technique (Based on the publication of Shao et al.) [46]. In the micropipette on the left a bead is aspired that can move freely within the glass walls. As the micropipette is pushed to the cell, the functionalized bead surface is brought into contact with the cell membrane using a gentle pressure. After the ligand-receptor bonds are formed, the bead is sucked into the micropipette with a controllable force. The point at which the bead detaches is the adhesion force as measured by this technique. Alternatively, the bead can be replaced with a spherical cell (Spillmann et al.) [119] to directly study cell-cell interaction.

a. Number of cells in an experiment

One cell/experiment.

\section{b. Typical force range}

A spherical object either a cell (e.g. human neutrophil) or a bead is used as a MAT transducer and it can exert forces lower than 10-20 pN [46]. Between the transducer and the pipette wall, a small clearance is necessary to allow free movement of the transducer inside the pipette. A freely sliding cell or bead is used as a force transducer. A positive pressure allows the bead (which is coated with the protein of interest) to contact and adhere to the cell [107]. Then, a constant suction underpressure provides the tensile force to break the adhesive bond. According to the diameter of the pipettes $(1-10 \mu \mathrm{m})$, the force range is $10 \mathrm{pN}-1 \mathrm{nN}$ [45]. The force exerted by the static cell (or bead) can be determined as follows: 


$$
\mathbf{F}=\pi R^{2} \mathbf{p} \Delta p
$$

where $R_{p}$ is the radius of the pipette, $\Delta p$ is the suction underpressure [80]. A bead was partially aspirated by a micropipette as described by Shao and Hochmut (1996) [107]. The diameter of the pipette was smaller than the bead, thus the bead was attached to the opening of the pipette. Another micropipette was used to aspirate a neutrophil cell. Diameter of this pipette was slightly smaller or equal to the diameter of the neutrophil. Adhesion strength is defined as the minimum force needed to detach a single cell from its substrate [38]. The technique was used to determine the minimum force $(45 \mathrm{pN})$ necessary to form a membrane tether from neutrophils [107]. The smallest bead $(3.2 \mu \mathrm{m})$ applied, resulted in a force of a few $\mathrm{pN}$. As a high force limit, hundreds of $\mathrm{nN}$ could be exerted [46].

\section{c. Experiment duration}

Lomakina (2004) hold a bead and a neutrophil in contact for a user-specified length of time (2s and $1 \mathrm{~min}$ ) and then separated them [120].

\section{d. Advantages}

The strength of the MAT is in its simplicity. It can measure the force between cells without attaching cells onto a solid surface. Cell-cell interactions can be studied directly. Interestingly, a spherical cell can be used as a force transducer [46]. A constant localized force can be imposed to monitor the effect of the force on single-bond kinetics [46]. While the low force sensitivity of the MAT is similar to that of optical tweezers, it can exert much higher forces as well [46].

\section{e. Disadvantages}

One of the cells (or probe) has to fit snugly inside the pipette. Forces smaller than $10-20 \mathrm{pN}$ cannot be measured precisely when the diameter of the pipette is $\sim 10 \mu \mathrm{m}$ [107]. As the adhesion between the bead-transducer and the pipette wall would affect the measurement, it is important to insure that the bead does not adhere to the pipette wall [46]. Evaporation in the chamber can be a significant technical issue [107]. 


\section{f. Main applications}

Viscoelastic properties of soft cells e.g. red blood cells, white blood cells; and more rigid cells, such as endothelial cells can be measured with it [45]. Micropipette suction is a versatile method to study mechanical properties of living cells and to examine the viscous response of solid cells e.g. endothelial cells, chondrocytes [45]. It can measure cell-cell interactions, directly Lomakina et al. [46],[119],[120] investigated interactions between neutrophils and ICAM-1 coated substrates using 2 micropipettes. One of them (stationary pipette) hold the bead and the other hold the neutrophil to manipulate the cell [120].

\subsection{Computer-controlled micropipette}

Computer-controlled micropipettes can manipulate and sort cells in a Petri dish, individually [121],[122] (Fig.11). Cells are selected on the basis of their phase contrast and/or fluorescent images). Sorting is performed by a micropipette with an aperture of 10-70 $\mu \mathrm{m}$ with a sorting speed of 3-4 cell/min. After sorting, single cells are deposited into another Petri dish/multiwall plate/PCR tube or glass cover slip in a minute volume of liquid in the nanoliter-microliter range. Individual cells inside the drops on the glass cover slip can be studied with high resolution, immediately after sorting [123]. The technique is suitable for high-throughput single cell adhesion force measurements by repeating the pick-up process with an increasing vacuum. Adhesion force between individual human white blood cells and specific macromolecules were studied with the technique [124],[125],[126].

Hundreds of cells adhered to specific macromolecules can be measured one by one in a relatively short period of time $(\sim 30 \mathrm{~min})$. 


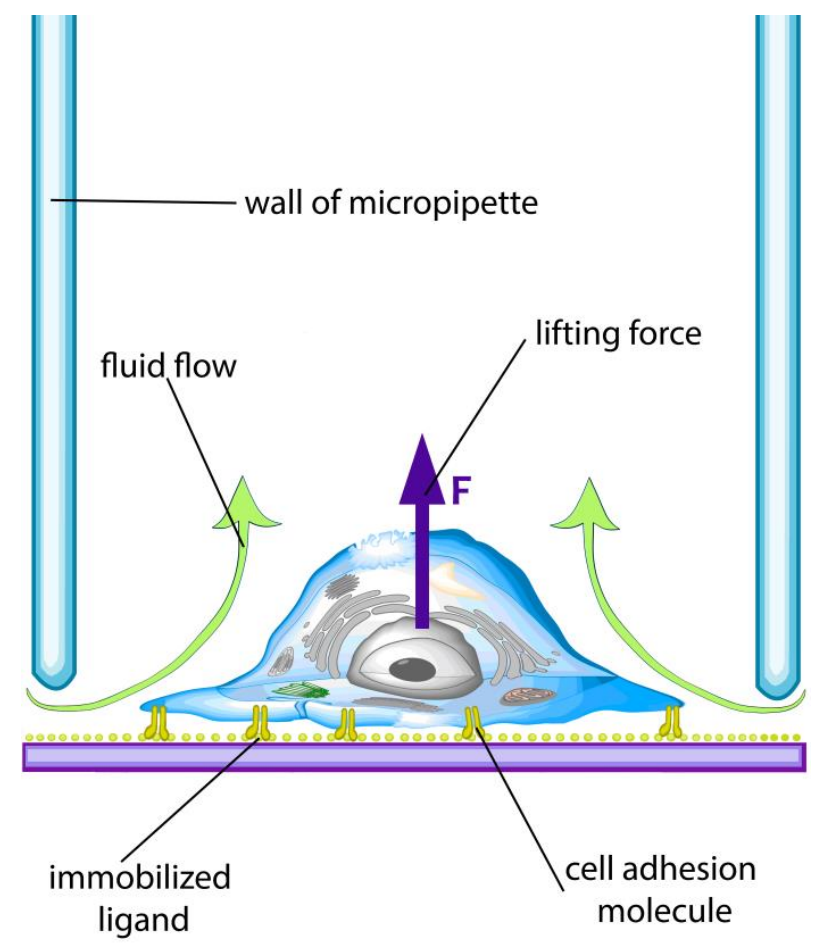

Fig.11 Schematic illustration of the computer controlled micropipette. The cells are approached by a micropipette from above, then a negative pressure is applied generating an upward fluid flow. If the lifting force is greater than the adhesion force between the cell and the surface, the cell is aspired. By increasing the vacuum in steps, the adhesion force distribution can be measured on a relatively large population of cells as the computer guides the micropipette through the Petri dish. The bottom surface can be functionalized by specific natural or artificial ligands.

\section{a. Number of cells in an experiment}

Single cell measurements in a cell culture dish containing hundreds of cells can be performed. In our experiments the total number of human immune cells probed by the micropipette was 200-600 for each of the three cell types [23].

\section{b. Typical force range}

Experimental vacuum value in the syringe can be converted to hydrodynamic lifting force acting on single cells on the basis of computer simulations of the flow in the micropipette. To estimate the lifting force acting on a real cell, the total force on a model cell (e.g., a hemisphere with a diameter of $20 \mu \mathrm{m}$ ) can be determined in 3D simulations. 
In our experiments with human monocytes, adhesion force of most cells fell into the $[0,2] \mu \mathrm{N}$ interval on the fibrinogen surface [23].

\section{c. Experiment duration}

Duration of the adhesion force measurements is typically $30 \mathrm{~min}$ [23].

\section{d. Advantages}

It can measure the adhesion force of individual cells with relatively high throughput: hundreds of cells in $\sim 30 \mathrm{~min}$, especially when compared to AFM or FluidFM. Measurements can be carried out on cells incubated on the specific surface for several hours or days to investigate physiological, potentially strong cell adhesion. The device can be mounted onto a normal inverted microscope. Both biologically and medically relevant results gained with the automated micropipette were reinforced in standard microfluidic shear stress channels. Automated micropipette offers a higher sensitivity than the measurement using the shear stress of a microfluidic channel [23] and it has less experimental side-effect than the shear stress channel. Cells usually become elongated and aligned to the direction of the flow in a shear stress channel. Similar effect was not observed in the experiments with the micropipette.

\section{e. Disadvantages}

A drawback of the technique as compared to AFM: to calculate the value of the adhesion force, hydrodynamic simulations depending on cell size (and less sensitively on cell shape) have to be carried out. However, computer simulations are not needed when different cell types or different treatments have to be compared without a need for a scaled value of the adhesion force. 


\section{f. Main applications}

The adhesion force of cells attached to specific molecular surfaces can be accurately probed. Measurements can be carried out on cells incubated on the specific surface for several hours or days to investigate physiological cell adhesion. Cell-cell interactions can be also studied with this method [124].

\section{Optical tweezers (OT)}

Laser tweezers were developed for the microscopic manipulation of cells and organelles. Conventional manipulation techniques - including optical tweezers/optical traps, magnetic tweezers, acoustic traps and hydrodynamic flows - cannot achieve high sensitivity and high throughput at the same time.

Conventional OT (Table 3) (Fig.12) use a strongly focused Gaussian laser beam to trap and manipulate microscopic objects such as small dielectric spherical particles (bead) [127]. Trapping lasers operating in the near infrared regime $(800-1100 \mathrm{~nm})$ minimize optically induced damage in biological specimens [128]. High NA (typically 1.2-1.4 NA) microscopic objective lens is used to focus the trapping laser [127]. A small bead is captured in an optical trap. The bead is positioned to touch the surface of a cell, and then the bead is pulled away from the cell until the chemical bond breaks. The force between the bead and the cell is determined on the basis of the displacement of the bead from the focus perpendicular to the optical axis. Optical tweezers allow fine control of positioning ( $\sim 10 \mathrm{~nm}$ for trap beam stability) and of forces $(\sim 0.1 \mathrm{pN}$ resolution) on a wide range of particle sizes $(25 \mathrm{~nm}$ to $25 \mu \mathrm{m})$ in a non-invasive manner [129],[130]. Owing to their precisely controlled force-exerting characteristics, OT are often used for a variety of mechanical force measurements in the $\mathrm{pN}$ range for single cells. Although most cells cannot be directly grabbed by the OT due to their size or shape, a small number of cell types such as yeast cells, RBCs and spermatozoa are readily tweezed and provide model systems for such force studies [131]. For those cells that cannot be directly tweezed, the use of microspheres as handles for force probes has allowed the measurement of cellular properties such as membrane tension [127]. 


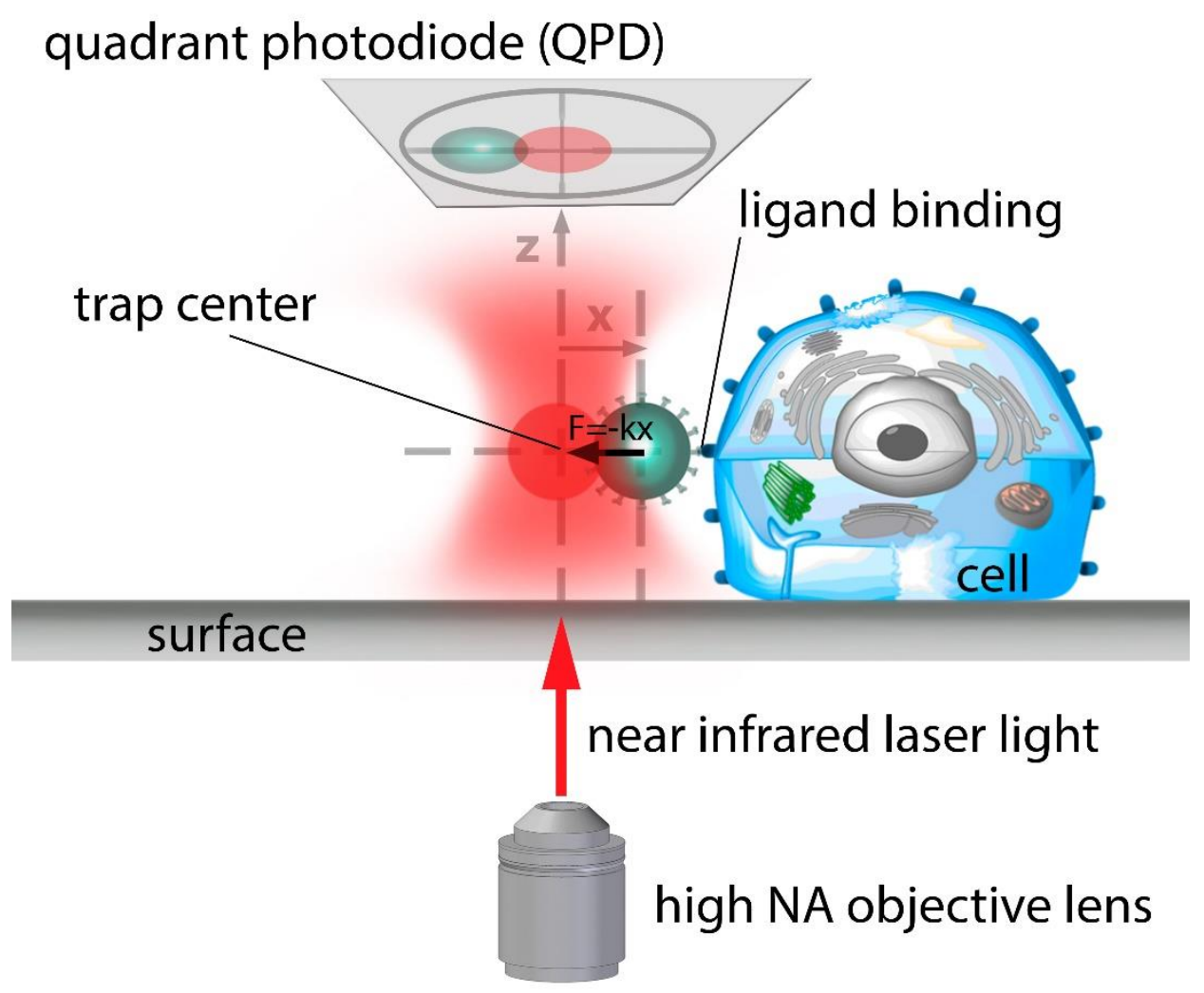

Fig. 12 An optical trap is created by focusing a near infrared laser light to a diffraction-limited spot with a high numerical aperture (NA) microscope objective. The laser beam used for trapping has a 2-D Gaussian intensity distribution with an intensity gradient in the $x$-and y-plane (perpendicular to the beam axis). A particle (bead) is captured in the optical trap and positioned to touch the surface of a cell. Then the particle is moved away from the immobilized cell. The force between the bead and the cell is determined on the basis of the displacement (x) of the bead from the focus perpendicular to the optical axis. The particle displacement changes the intensity distribution of the transmitted infrared light. The shift of the intensity maximum can be detected with a quadrant photodiode (QPD). The signal of the QPD can be converted into units of displacement ( $\mathrm{nm}$ ) and force (pN).

a. Number of cells in an experiment

1 cell/experiment.

\section{b. Typical force range}

0.1-100 $\mathrm{pN}$ [127]. The trapping force depends on the intensity of laser power, the shape of laser focus, the size and shape of the trapped particle and the index of refraction of the trapped particle relative to the surrounding medium. It is difficult to measure the trapping force directly but there are several ways to calibrate it [127]. The external forces applied to a single particle within an optical trap can push a single particle away from the focus, and the force from the OT 
draws the particle back to the center of the trap. In the equilibrium position, the external force equals the force from the OT. For a small displacement, the force from the OT, termed as restoring force, can be estimated by:

$$
\mathbf{F}=-\mathbf{k X}
$$

where $k$ is the trap stiffness and $X$ is the displacement of the particle from the center of the trap [127],[130].

\section{c. Experiment duration}

A bead carrying ligands on its surface is brought in contact with the cell. After an incubation time of a few seconds, it is pulled away from the cell applying stress to the chemical bonds [132]. When the cell itself is trapped for several minutes at high power $(\mathrm{P}>300 \mathrm{~mW})$, membrane stiffening can be observed, and the cell elasticity is affected. Thus the manipulations on the same cell should take normally less than $15 \min$ [133].

\section{d. Advantages}

OT offer exceptionally high force sensitivity [106]. The technique can be applied to measure weak forces of single molecules that cannot be achieved by traditional AFM or most of the alternative tools [127]. High spatial resolution [130]. Non-contact force measurement [127],[131].

\section{e. Disadvantages}

Optical manipulation is limited in space due to focusing requirements [106]. Choice of the laser can be critical depending on the application. Laser absorption by the sample can lead to damage as the highly focused spot has an intensity in the range of $\mathrm{MW} / \mathrm{cm}^{2}$ [131]. Thus wavelength is a central parameter when cells are trapped: wavelengths below $800 \mathrm{~nm}$ can easily damage cells [134]. Thermal effect of the high laser intensity has to be considered [127],[135].

Trapping in cell extract or in a medium containing impurities is generally precluded as trapped impurities can distort or mask the position signal. Still the optical trapping of lipid vesicles 
within eukaryotic cells [136], and organelles in yeast cells [137] have been successfully implemented.

The applied force is limited to a maximum of $100 \mathrm{pN}$ set by the maximum laser intensity in the specimen plane [130].

\section{f. Main applications}

Various cell types, including mammalian cells (red blood cells, nerve cells, gametes and stem cells), yeast cells [138],[139],[140] and bacteria, such as Escherichia coli have been studied [127].

In the binding experiments, the 3D manipulation capability is exploited to impose a specific interaction between the trapped object and a fixed partner, and to measure the force and displacement resulting from the interaction [130],[141]. A particle is decorated with ligand molecules binding to the cell surface. The optical trap pulls the particle away from the cell until the chemical bond breaks [132]. Measurement of the force and displacement of optically trapped kinesin coated beads moving along fixed microtubules was pioneered by Block et al. [142],[143]. The binding probability and unbinding force was measured between virus coated beads and erythrocytes. The binding force of single fibrinogen/fibronectin-integrin pairs could also be quantified in living cells [143],[144]. OT can capture the force characteristics of intermolecular bonds on the cell surface [132].

In the so-called tether-pulling experiments, OT have been applied to study the mechanical properties of cell membranes. Tether extraction is an accurate method to quantitatively characterize the plasma membrane. To form a membrane tether, micrometer-sized particles (beads) are used to grab the cell membrane. A bead trapped by the OT is held on the cell plasma membrane for a few seconds, and then moved away from the cell to pull out a membrane tether, a thin cylindrical strand of plasma membrane between the bead and the cell [145],[146]. The force needed to manipulate the bead can be measured by OT [127]. Thus the bending rigidity of the membrane can be determined [132].

OT can probe the viscoelastic properties of whole cells under physiological condition. For this two optical traps are applied to attach beads to two opposite points of the cell. It can give an insight into the internal structure and organization of the cell [132]. 


\section{Atomic force and fluidic force microscopy}

Atomic force microscopy (AFM) developed by Binnig et al. (1986) [147] can be applied to capture single cells with its functionalized cantilever gently pressed to the cell (Fig.13 A). This in turn converts the living cell to a probe brought into contact with a functionalized surface or another cell (Fig. $13 \mathrm{C}$ ). Subsequently, the cantilever is pulled back at a constant speed, detaching the cells from its binding side. Deflection of the cantilever is proportional to the force acting between the cell and the substrate. It is recorded as a force-distance curve [43]. Deflection of the cantilever is detected with a laser beam focused on the top side of the cantilever and reflected into a quadrant photodiode [148].

In the force spectroscopy mode, AFM (Table 4) acts as a versatile tool to probe nanomechanical properties and to extract quantitative parameters of biological systems, including tissues, cells, proteins and nucleic acids, and of biomimetic systems, such as functionalized surfaces or matrices. AFM-based force spectroscopy [43],[149] involves an atomic force microscope tip to locally record interactions with the sample or its nanomechanical properties. Approach and retraction force-distance curves characterize the sample deformation and tip-sample adhesion, respectively [150]. Analysis of the approach force-distance curve, and in particular the region describing indentation, allows properties including deformation, elasticity and dissipation to be determined. The retraction curve quantifies the adhesion force between the tip and sample.

Single- molecule force spectroscopy (SMFS) [151],[152] is frequently applied to detect the binding strength of ligand receptor pairs. It was applied to measure the force required to unbind streptavidin and biotin [153], it was quickly recognized that measuring rupture forces provides information about the kinetic properties of a bond.

Single-cell force spectroscopy (SCFS) [154] measures the adhesion of a single cell to a biointerface, which can be tissue, another cell or a surface functionalized with ligands. A single cell is attached to the free end of a tipless cantilever [150]. A number of methods have been developed to attach the cell onto the AFM cantilever and to allow probing cell-cell or cellsubstrate interactions [148]. Specific receptor-ligand interactions [155],[156] electrostatic interactions [157], glue [158] or chemical fixation [159] can all be applied. An important issue when applying these protocols is to make sure that the native surface of cells is not altered or denatured. In this respect, an appropriate approach is to attach individual cells to the AFM cantilever with lectin. This method allowed the measurement of the adhesion force between 
two neighboring cells of D. discoideum on the single-molecular level [148],[155]. After that, the functionalized cantilever is lowered into contact with a trypsinized cell, which readily attaches to the cantilever. Then, the probe cell is brought into contact with a biointerface for a given contact time and force, and then withdrawn while a force-distance curve is recorded. Analysis of the force curve provides the maximum adhesion force of the cell. This approach allows investigate how cells strengthen adhesion to ECM proteins or other substrates [150].

AFM-based force spectroscopic modes enable the characterization of single receptor-ligand bonds, protein unfolding and refolding, and the mechanoelastic properties of peptides, nucleic acids, sugars and polymers. Cell adhesion to the interface of substrates, other cells or tissues can also be quantified using such modes.

AFM can be used in 2 ways: it can either measure the adhesion of the cantilever-attached cell to the substrate surface or the adhesion of the cell immobilized on the substrate to the cantilever [149] .

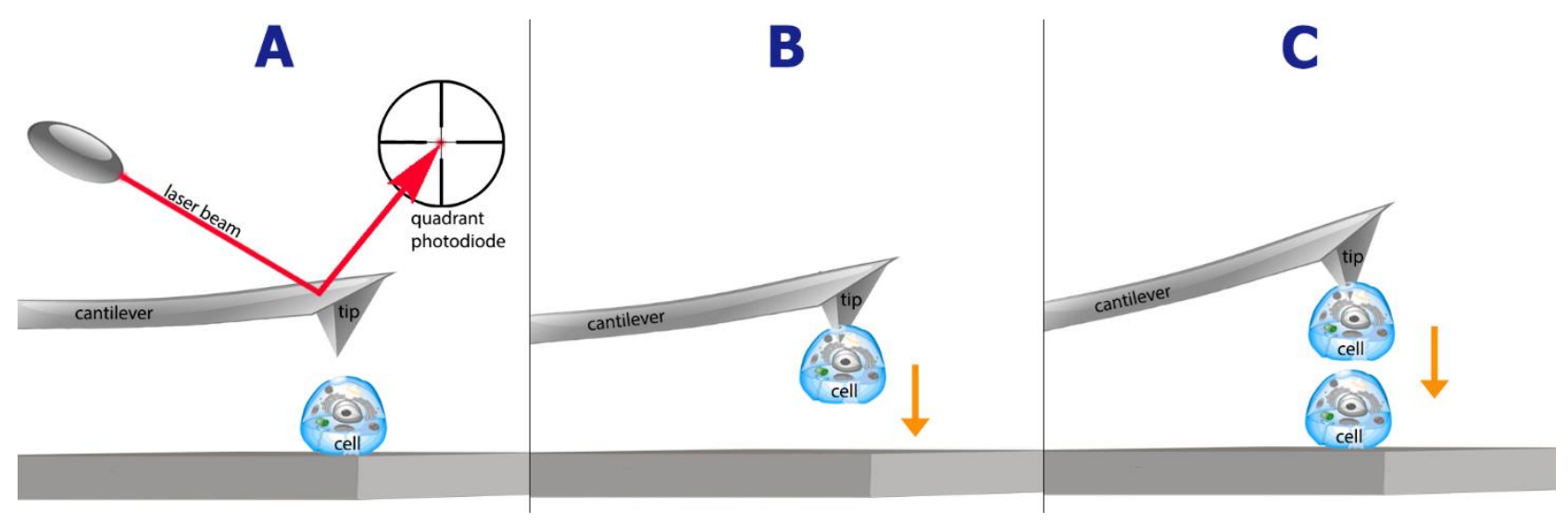

Fig.13 Schematic illustration of atomic force microscopy applied for cell adhesion measurements. The interaction between the cell and the tip is measured through the displacement of the laser beam on the photodiode caused by the deflection of the cantilever. The latter acts as a spring probing the force acting between the tip and the cell. The tip surface can be functionalized with a molecule of interest then it is pushed to the cell for a predetermined time that allows the receptor-ligand bonds to form (panel A). As the tip is pulled back with a controllable speed, the distance-force curve can be registered by measuring the signal on the photodiodes. As an alternative to tip functionalization with biomolecules, a living cell can be attached to the tip (panel B). Then the cell attached to the cantilever is pushed to the functionalized substrate surface or to the other cell on the substrate, thus allowing the direct measurement of cell-cell adhesion (panel C). Since both the spatial resolution and force sensitivity are high, the AFM was the first method capable of measuring cell adhesion on the single receptor level. 


\subsection{AFM to probe force normal to the surface}

\section{a. Number of cells in an experiment}

Each cell requires a separate cantilever that must be functionalized (typically $\sim 30 \mathrm{~min}$ ) and calibrated, which impedes the ability to obtain high-throughput measurements [48]. At least three force curves have to be recorded at different locations in each cell. Although it is beneficial to take multiple curves on each cell for reliable statistical data, taking too many force curves can lead to changes in cell stiffness due to the mechanical stress caused by the AFM probe. AFM yields only a few measured cells (from 1 to 5) per condition in most studies [160].

\section{b. Typical force range}

The AFM (Binnig et al., 1986) can be used to measure nano-newton to pico-newton forces and micrometer to $0.1 \mathrm{~nm}$ displacements [161]. Imaging in aqueous solution allows observation of biomolecules under physiological conditions and estimate strong, capillary forces between the sample and probe when the imaging is done in air [162],[163]. In order to prevent deformation of weak biological sample, a vertical force is used (50-100 $\mathrm{pN}=$ minimum force). At 100-1000 $\mathrm{pN}$ force, the biological sample is reversibly deformed, and above this value irreversibly [163],[164],[165]. AFM can be used to analyze accurately and then remove genetic material from the chromosome [162],[166]. Antibodies that specifically bind to the cytoplasmatic membrane surface can be removed with smaller than $0.8 \mathrm{nN}$ [162],[163],[167]. In the future it is expected that the use of smaller cantilever improves the resolution, allowing measurement of the smaller non-binding forces.

AFM-based SCFS (single cell force spectroscopy) enables measurement of wider force range $(5 \mathrm{pN}-100 \mathrm{nN})$ [149].

An individual WM115 cell was bound to a lectin functionalized cantilever with a given force $(500 \mathrm{pN})$ by Puech et al. and then the cantilever with the bound cell was slowly retracted 100 $\mu \mathrm{m}$ from the substrate. This allowed a strong adhesion of the cell to the cantilever (5-15-min). After that, adhesion of an individual, captured melanoma cell and a model endothelial layer of HUVEC cells were tested. A given force (few $100 \mathrm{pN}$ ) was applied on the cell layer for a certain time (range of sec). Finally, probe cell was separated from the surface while detachment event 
was recorded [44]. This work described that, AFM is a sensitive and quantitative method to measure long-distance cell-adhesion forces.

A D. discoideum cell was bound to the AFM cantilever by Benoit et al [155]. Then a target cell was placed at the bottom of the Petri dish and it was approached while a defined repulsive contact force was established. This force was held constant to enable establishment of cell adhesion. While the cantilever was retracted, it was recorded the force as a function of the distance until connection between the cells was broken. It was allowed the interaction for $20 \mathrm{~s}$ at the force of $150 \mathrm{pN}$. Adhesion between these cells produced unbinding forces of the order of $1 \mathrm{nN}[155]$.

SCFS (single-cell force spectroscopy) was used by Taubenberger et al. [168] to investigate the $\alpha 2 \beta 1$-mediated cell adhesion to collagen I.; they compared adhesion of CHO-WT and CHOA2 cells to collagen. It was found that, CHO-A2 cells adhered to collagen ( $40-600 \mathrm{pN})$ strongly, than another cell $(<50 \mathrm{pN})$. When contact time was $<120 \mathrm{~s}$, usually 2-5 force cycles/cell were carried out, whereas for longer contact time, 1-2 force curves/cell were recorded [168].

Lehenkari and Horton determined integrin-ligand interaction of osteoclasts. Integrin-binding forces were measured in intact cells by AFM for several RGD-containing ligands with a range of 32-97 pN. It was reported that, AFM can be applied in cell biology studies and it provides an opportunity to analyses receptor-ligand interactions in the cell membrane [10].

\section{c. Experiment duration}

First, a chemical functionalization of the cantilever is needed allowing irreversibly " glue" the cell of interest to the cantilever; where the lever is coated with wheatgerm agglutinin for at least $1 \mathrm{~h}$. Consequently, each cell requires a separate cantilever that must be functionalized (typically $\sim 30 \mathrm{~min}$ ) and calibrated, which impedes the ability to obtain high-throughput measurements [48]. The AFM cantilever is positioned using a piezoelectric crystal, and its deflection is measured by laser reflection onto a split photodiode. Positioning precision in the z-direction is $1 \AA$, and force sensitivity is within $3 \mathrm{pN}$. The cantilever is moved with a velocity of $2.5 \pm 0.5$ $\mu \mathrm{m} \mathrm{s}^{-1}[155]$.

Cells are immobilized on a substrate or on the force sensor itself [155] (Fig.13 A,B). The sensor surface is functionalized with an adhesive molecule [169] to attach the cell to it. Cells immobilized on the sensor were used to investigate cell-cell interaction [161] (Fig. 13 C). To avoid scattering of the laser beam of the detection system, non- or weakly-adherent cells are 
removed by gently rinsing the dish. An attached cell is slightly loosened by pushing its flank with the side of the cantilever. The extreme end of the lever is then lowered onto the cell at a force of a few $\mathrm{nN}$ and hold in contact for $\sim 30 \mathrm{~s}$ to allow the lectin on the lever to bind; the cell is then lifted off the bottom of the dish [155].

Using AFM, it needs $\sim 10$ min for proper cell-cantilever interaction. In this technique, the force range is limited by the force with which the cell is bound to the cantilever, which usually results in the application of only relatively short contact times (msec-20min) [43],[170] between the cell and the substrate of less than one hour before the adhesion force exceeds the detectable range [48],[161].

\section{d. Advantages}

AFM can measure adhesion from a single molecular event in intact cells under physiological conditions. Both spatial and force resolutions are high. AFM has force sensitivity in the $\mathrm{pN}$ range and $\mathrm{nm}$ positioning accuracy, therefore atomic force microscopy is a powerful device to explore dynamics and strength of interactions between individual ligands and receptors. These studies require adhesion of specific biomolecules or cells onto the AFM tip or to a solid surface. Currently, AFM is the only force- measurement technique which can map and analyze individual receptors with nanoscale lateral resolution [148]. AFM has several unique properties: it can be operated in solution, allowing observation of biological structures in native environment [171]; individual proteins can be observed at a resolution >1 nm [165],[172] conformational changes of single biomolecules can be directly monitored [162],[165],[170],[173].

\section{e. Disadvantages}

State- of- the- art AFM measurements have limitations, for example adhesion measurements, which use single cells are time-consuming, costly methods. Only one cell can be characterized at a time. Each cell requires a separate cantilever which must be calibrated and functionalized [43],[48],[149] impeding to obtain high-throughput measurements [170]. Chemical attachment of the cell to the cantilever is cumbersome $(\sim 30 \mathrm{~min})$ and it can alter the physiology of the cell [161],[174]. High number of detachment force-distance curves need to be measured to gain reliable statistics which restricts the length of the contact time. Usually only a relatively short contact time is established between the cell and the substrate (msec-20min) [43],[170]. Another 
challenge is to develop a fast scanning AFM as the temporal resolution of the method is limited [148]. Thermal drift is almost unavoidable in AFM experiments which complicates longcontact-time experiments (>20min). Strong adhesion of the cells falls out of the force range of the technique after a longer contact time $(>1 \mathrm{~h})$.

\section{f. Main applications}

Due to its wide force detection range, it can measure both the adhesion of a whole cell and interaction [175] in a ligand-receptor system [43],[149]. It can study the dynamic formation of cellular adhesion. It has been adapted to measure cell-cell and cell-substrate adhesions. AFM can be combined with modern optical imaging techniques [43]. It can quantify forces guiding microbial cell adhesion [78],[175],[176],[177],[178].

\subsection{AFM to probe tangential/lateral force}

Manipulation force microscopy [2] (Table 4), an atomic force microscopy can measure the force that dislodges micro-sized objects attached to the surface. The technique applies laser beam deflection and an inclined AFM cantilever to measure the force. The cell is brought into contact with the cantilever, and a tangential force is applied gradually. Finally, the cell is released from the surface as all adhesion bonds are broken.

\section{a. Number of cells in an experiment}

Adhesion strength of cervical carcinoma cells were examined by this technique. In an experiment, force measurement on 200-300 cells were carried out [2].

\section{b. Typical force range}

Adhesion force of several hundred $\mathrm{nN}$ was measured on different surfaces [2]. A force of 19 $\mathrm{nN}$ was required to detach E. faecalis cells from hydrophobic materials, and $6 \mathrm{nN}$ to detach from hydrophilic materials [176]. Chang and Hammer in their numerical simulations of functionalized microbeads found that the lateral detachment force is several times lower than the perpendicular detachment force. Thus a tangential force is considered to be more effective 
to detach a particle than normal forces [177]. The reason is thought to be the low ratio of the bond length to the bead radius.

\section{c. Experiment duration}

Adhesion time is usually between 10 and 90 min [2].

\section{d. Advantages}

Studies have shown that the lateral force required to displace a bacterial cell is considerably (up to 10 times) smaller than the perpendicular force [177],[178]. Enables the real-time imaging of bacterial adhesion and aggregation under physiologic conditions or affected by antibiotics [176].

\section{e. Disadvantages}

Interpretation of the experimental data is not straightforward [2]. The measured force depends strongly on the details of the experiment: the shape of the tip, the scanning speed, the torsional spring constant of the cantilever, the exact direction of the applied force, and the nature of the binding between the cell (or bead) and the substrate [78],[179].

\section{f. Main applications}

Binding force of protein-covered silica spheres adsorbed to polystyrene surfaces [180]. Adhesion force of individual cervix cells to various substrates [2]. Characterization of medicalgrade polymers and their resistance to microbial adhesion and biofilm formation [176].

\subsection{Fluidic force microscopy (FluidFM)}

FluidFM (fluidic force microscope) is a unique micromechanical and microfluidic device that combines the force-controlled high spatial precision of AFM with the capability of direct liquid delivery by microfluidics. The needle-like AFM probe or the bare cantilever of the FluidFM contains a fluidic microchannel inside (Fig.14). It is directly connected to an external fluid circuit controlling the pressure and thus the flow in the microchannel. This novel technique can both mechanically manipulate living cells and microinject biochemical reagents into them 
[181]. The whole FluidFM BOT system involved an inverted optical microscope [182]. Individual microbial (S.cerevisiae, C.albicans) and mammalian cells (HEK, HeLa) were used to measure the cell adhesion force [48]. FluidFM (Table 4) reuse the same probe for the measurement of multiple cells to record single cell force spectroscopy (SCFS) curves reducing the time required to obtain statistically relevant data compared with conventional AFM [48]. Trapping the cell to the cantilever occurs within a few seconds before the SCFS measurement. Then the cells can interact with the substrate or the other cell for a longer time.

During the measurement, first the cells are selected, and then it is approached with a set point (10 $\mathrm{nN}$ for yeast cells and $50 \mathrm{nN}$ for mammalian cells), after that it is followed a pause ( $5 \mathrm{~s}$ for yeast cell and $3 \mathrm{~s}$ for mammalian cell) with force feedback using underpressure and the cell is immobilized to the cantilever. While using AFM, it requires $\sim 10 \mathrm{~min}$ for cell-cantilever interaction but with FluidFM needs only $5 \mathrm{sec}$ underpressure for cell-cantilever contact. In the conventional AFM, cells are immobilized to the cantilever, while FluidFM to fix the cell to the cantilever, apply underpressure. Here chemical fixation of the cell to the cantilever is replaced so that cells are sucked into the aperture of a hollow cantilever (few sec). The cell release from the substrate so that it is applied an overpressure pulse makes the immediate reutilization of the cantilever possible, thereby resulting in the ability to perform serial measurements. Potthoff et al. have shown that FluidFM can increase the amount of data that can be recorded in a single day. Compared to the conventional SCFS, FluidFM based SCFS can be performed up to tenfold as many experiments / day and 200 experiments can be carried out with this technique compared to the conventional cantilevers [99]. This approach is similar to the microinjection with glass pipette, but there are differences. Microinjection requires optical microscopy. Cells are often damaged, however using AFM precise force feedback reduces potential damage to the cell [181]. 


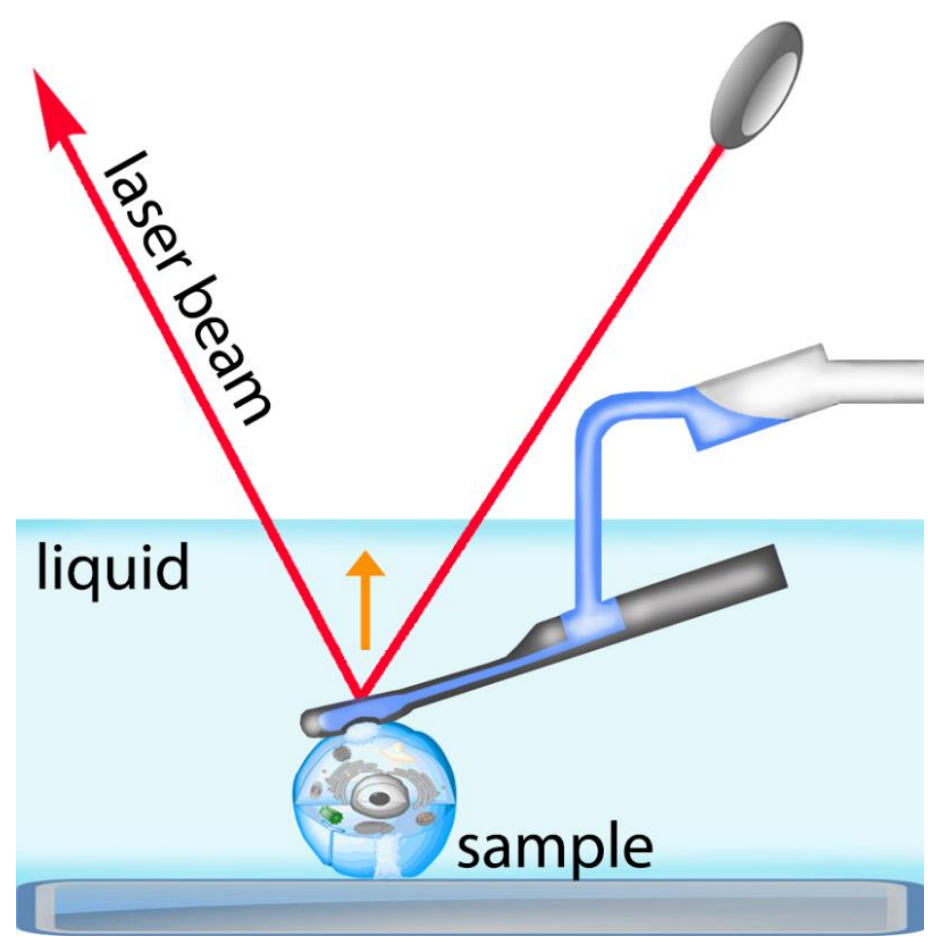

Fig.14 Schematic illustration of fluidic force microscopy. The nanofluidic channel inside the cantilever allows the grabbing of the cell by the cantilever or tip using a negative pressure. When the upper side of the cell is immobilized this way, the tip is moved upwards picking the cell up from the surface. This method can be used to directly measure the complete adhesion force and energy between the adhered cell and the surface in a less difficult way than using the traditional AFM method. Another advantage is the rapidity of the measurements, as the tip can be reused after $a \sim 5$ min washing step. The upper limit of the measured force is set by the aperture of the fluidic microchannel and the spring constant of the cantilever. Since there are multiple tip designs available, the same device can be used for other applications, such as cell injection, lithography, etc.

\section{a. Number of cells in an experiment}

It was compared the maximum adhesion strength of 2 types of yeast cells (S.cerevisiae, C. albicans) to hydrophobic and hydrophilic surface, after an adhesion time of $15 \mathrm{~min}$. Then HeLa ( $n=11-12$ cells were examined serially) and HEK cells ( $n=8-9$ cells) were compared on glass and fibronectin-coated surfaces. Up to 200 yeast and 20 mammalian cells per probe can be performed with this technique [48]. In half an hour, $\sim 10$ cells can be studied using this technique.

\section{b. Typical force range}

The measured adhesion forces were between $500 \mathrm{pN}-1.6 \mu \mathrm{N}$ [48]. 
It has been shown that, adhesion force is increased as a function of incubation time and dependent on the temperature. It has been demonstrated rapid and serial yeast cell adhesion which can available with FluidFM so it can be investigated adhesion strength to the specific substrates and it can be determined long-term adhesion interactions.

It was studied the adhesion of C. albicans to hydrophobic surface that was $39 \mathrm{nN}$ and to hydrophilic surface was $10 \mathrm{nN}$. Adhesion strength of S.cerevisiae hydrophilic and hydrophobic surfaces was 2 and $5 \mathrm{nN}$, respectively. In both cases the same behavior was occurred; adhesion to the hydrophobic surface was stronger.

It was studied whether FluidFM is suitable to detach mammalian cells from standard surfaces while long-contact time is established between cell and substrate but only a minimum time is required to fix the cell to the cantilever. HeLa cells on fibronectin surface showed 40-fold greater adhesion strength as compared to yeast cells. HeLa was compared to another cell line, HEK, and adhesion of this cell to fibronectin was $53 \mathrm{nN}$ which is much smaller than in case of HeLa [48].

\section{c. Experiment duration}

Compared with the conventional SCFS, using FluidFM-based SCFS allows to carry out 10times more experiments (using FluidFM can be performed up to 200 attempts while using AFM only 20 attempts). Only a few minutes is needed to target, immobilize, and release the cell as well as to change the cantilever position to the next cell [48].

\section{d. Advantages}

It can be measured the adhesion force directly. It has been demonstrated a fast and serial yeast cell adhesion measurements. It can be monitored adhesion of single cells to specific substrates and can be quantified the long-term adhesion interactions. The technique enables long contact times (orders of magnitude) between the cells and substrates. It has been demonstrated the universality and broad applicability of this method for different cell types. It can be measured higher cell-substrate adhesion forces (one order of magnitude), than using AFM [43]. Much shorter measurement time and many more adhesion measurements can be performed with it. Instead of chemically immobilizing the cells to the cantilever as in conventional AFM experiments, it is applied underpressure to fix the cell to the cantilever aperture [183]. 


\section{e. Disadvantages}

Using mammalian cells, it was unable to obtain the same quantify of serial measurements which were monitored with yeast cells, but it could be recorded 10 times more force curves than with conventional SCFS [48]. Throughput is lower [181] than that of the automated micropipette. Microfabricated cantilevers come with a high measurement cost. Cells come into direct contact with the cantilever potentially perturbing or damaging cells [181].

\section{f. Main applications}

The universality and versatility of the FluidFM opens the way for original experiments in physics, materials, sciences, chemistry and molecular electronics. The method reduces the time required to obtain statistically relevant data compared with conventional SCFS. The use of FluidFM based SCFS enables AFM based adhesion force measurements [48],[184]. This is a universally applicable method for living cells. It can measure the adhesion force of those cells that were difficult or impossible to measure with conventional AFM [48]. Microinjection of cells [185]. It can be used for printing of 2D surface patterns with various formations [186] or for precisely controlled template-free 3D micro- and nanoprinting [187],[188]. Micropatterning of living mammalian cells on carboxymethyl-dextran (CMD) hydrogel layers was presented using the FluidFM BOT technology [182].

\section{Cell traction force microscopy and FRET force sensors}

\subsection{Cell traction force microscopy}

Cell traction force microscopy (CTFM) [49] (Table 5) enables the force (mechanical stress) field generated by single cells on an elastic substrate to be reconstructed with a resolution of $\sim 1-10 \mu \mathrm{m}$. The workflow of the technique is built up of four subsequent procedures, namely: 1) preparation and characterization of the substrate; 2) microscopic imaging of cells and deformation markers inside the elastic substrate; 3) computational recovery of the displacement field of the substrate; 4) computational determination of the traction stress field from the displacement field, based on an elastic model. 
Most often, the substrate is a polyacrilamide (PA) gel coated with proteins that specifically promote cell adhesion (Fig. 15). PA has the advantage that it is linearly elastic within a wide range of mechanical stresses and thus completely recovers after stress removal [189]. Furthermore, by varying the degree of crosslinking in the PA gel, its rigidity can straightforwardly be tuned in the physiologically relevant range of $0.1-100 \mathrm{kPa}(1 \mathrm{kPa}=$ $1 n N \mu m^{-2}$ ). The PA gel is embedded with randomly distributed fluorescent beads (usually 200$500 \mathrm{~nm}$ in size) which are then used as markers of the substrate deformation.
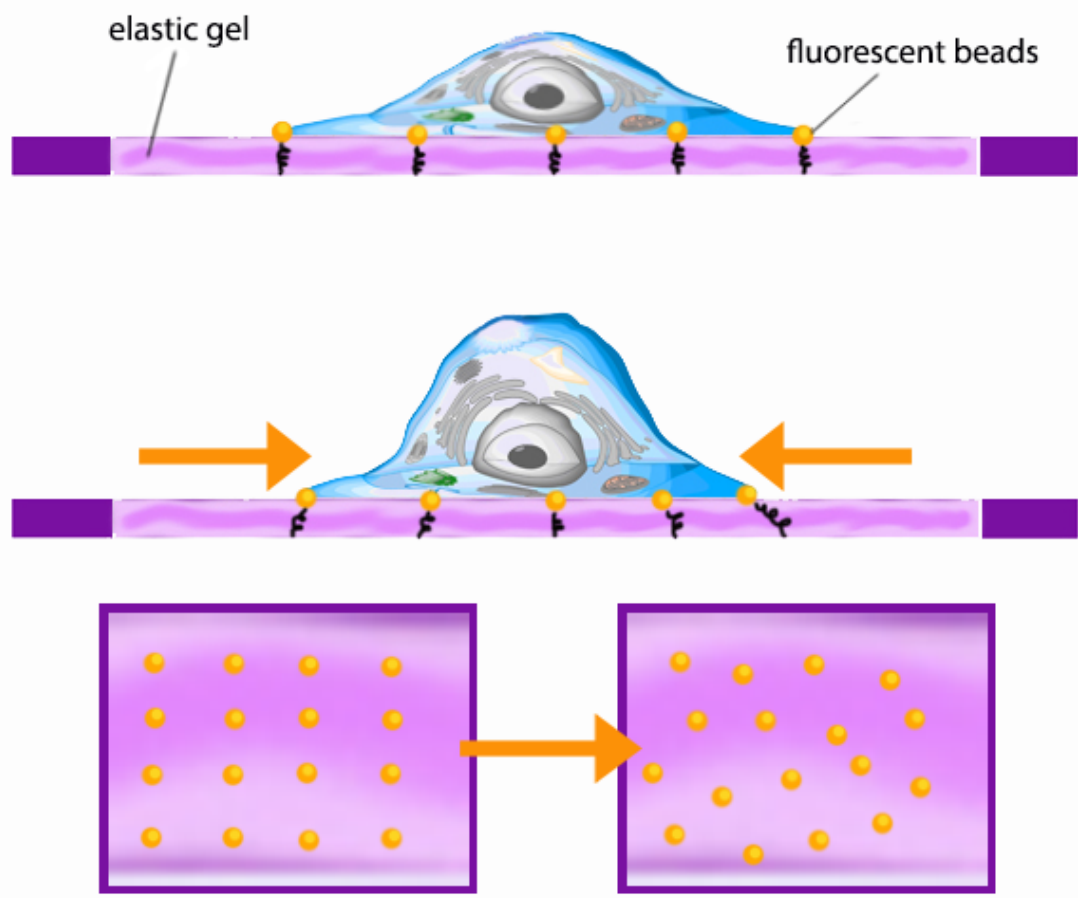

Fig.15 Schematic illustration of the principle of cell traction force microscopy. The substrate (in purple) is randomly embedded with fluorescent beads with a diameter of around $500 \mathrm{~nm}$. Then the cells are placed on the surface and let to adhere for a predetermined time. As the cells interact with the adhesion proteins on the polyacrilamide substrate, a force is exerted that rearranges the previously recorded bead distribution. The fluorescent patterns before and after cell adhesion are captured by wide field microscopy. From this displacement field, the traction field can be reconstructed by an elastic computational model with a spatial resolution of $\sim 1 \mu \mathrm{m}$. Using the $3 D$ version of the method, the traction field can be measured in $3 D$ cell cultures. CTFM has been successfully applied for the mapping of individual cell's traction fields as well as for the examination of the migration of cell groups.

\section{b. Typical force range}

Traction force microscopy relies on culturing cells on soft compliant polymer films that deform under tension [190]. These deformations are then deconstructed using computational finite 
element analysis to calculate the lateral force vectors applied to micrometer elements. Using this method, the literature estimate for integrin tension within focal adhesions is approximately 2-3 pN per receptor [191]. The typical force range is $\mathrm{nN}$ in magnitude [191].

\section{c. Experiment duration}

Up to several hours when combined with time-lapse imaging. After pre-incubating the cells on the substrate for an arbitrary time, comes the imaging stage of the workflow when at least a set of three photomicrographs are taken. First the cell-substrate contact is imaged, often in simple phase-contrast mode. Next, the microbead distribution near the surface of the substrate is captured in fluorescent mode for the cases when i) the cells exert forces onto the substrate (force-loaded image) and when ii) they have been removed from it via trypsinization (forcefree image) [192],[193]. Fluorescent imaging is generally done with a wide field epifluorescent microscope.

\section{d. Advantages}

Since its introduction in 1996, CTFM has undergone impressive developments. Innovations at the substrate level gave rise to CTFM variants which characterize the substrate deformations in a more or less different manner as described above [194]. For instance, a CTFM variant utilizes a PDMS substrate with a flexible array of single micropillars which act as independent tiny strings. Unlike the original CTFM, this variant has the advantage that traction forces can be easily calculated from the deflections of the micropillars [194]. On the other hand, cell adhesion is artificially constrained to discrete islands, and the spatial resolution of the mapping of traction forces is limited by the number of the micropillars. Recent technological and/or computational advancements have led to the development of i) high resolution CTFM offering a spatial resolution of $\sim 1 \mu \mathrm{m}$ [190] or even super-resolution [195]; ii) 2.5D CTFM, which enables all components $(\mathrm{x}, \mathrm{y}, \mathrm{z})$ of the traction generated by a cell on a 2D substrate to be determined [192]; and iii) 3D CTFM, which permits traction force measurements for the case of cells embedded in a 3D matrix [196],[197].

\section{e. Disadvantages}


In order to recover the displacement field, the pixels of the force-loaded and force-free images have to be one by one appropriately matched (image registration problem). The most straightforward method would be to directly monitor the movements of the microbeads but given the high number (few thousands) of microbeads, this task is computationally demanding and is thus rarely used. Albeit alternatives to this method have been proposed, image registration methods continue to share some common problems, such as the deterioration of the displacement field when the beads become more sparsely distributed, or the difficulty of error estimation (for reviews see [193] and [194] ).

Nevertheless, once the displacement field is calculated, the deconvolution of the traction field remains the last step in CTFM to be carried out. It is critical to deliberately choose an elastic model to formulate the relation between the displacement and traction fields. Generally, the substrate is considered as a semi-infinite half space, thus only the substrate surface enters analysis and the simple Boussinesq equation [198] has to be solved. However, it has not got a unique solution and therefore regularization terms have to be added to exclude non-physical solutions. Furthermore, the inversion of the elastic equations, and thus the computed force field are very sensitive to noises. To circumvent this disadvantage, more sophisticated approaches have been proposed [193],[194].

\section{f. Main applications}

CTFM has hitherto been applied to map the traction field of individual cells [199],[200] and that of cell aggregates [201]; to detect phenotypic changes that are accompanied by a change in traction forces during cell differentiation [202]; and to investigate the migration of individual cells [203], as well as the collective migration of a sheet of cells [189],[204].

\subsection{FRET force sensors}

FRET (Förster/Fluorescence resonance energy transfer) (Table 5) is a form of non-radiative energy transfer between two fluorophores (donor and acceptor) [205] due to dipole-dipole interaction. Fluorescent organic molecules have been widely used as donors and acceptors and they offer advantages such as small size, compatibility with numerous and simple covalent 
coupling strategies, and a relatively strong optical signal. Careful selection of an appropriate donor-acceptor pair ensures high transfer efficiency and provides two measurable parameters: quenched donor photoemission and enhanced acceptor fluorescence [206].

FRET probability depends non-linearly on the distance between the donor and acceptor. This technique, capable of measuring distances on the 2-8 $\mathrm{nm}$ scale, relies on the distance-dependent energy transfer between the donor and acceptor fluorophores [207]. It is widely applied for mapping large scale protein structures as a “molecular ruler'”[205],[208],[209]. FRET measurements can follow receptor-ligand interactions, changes in protein conformation upon binding a target analyte or can be utilized to reveal the response to changes in the solution conditions (e.g., temperature or $\mathrm{pH}$ ). It can also monitor the nanometer scale displacements of cell adhesion ligands.

A molecular force sensor can be constructed by attaching the donor and acceptor to the ends of a molecular spring: a flexible chain of atoms, usually a polymer. The distance of the donor and acceptor changes, when the molecular spring is under tension [50], and thus the tension can be read out from the FRET signal (Fig.16). Tension across the cellular receptor of interest leads to an elongation of the force-sensitive unit, which then can be microscopically detected [210]. FRET-based biosensors need high sensitivity microscopy and appropriate data analysis algorithms to determine the force in cells [211]. The most frequently used method is based on intensity measurements, in which the donor fluorophore is excited and the emission intensities of donor and acceptor fluorophore are used to calculate the FRET ratio. However, these measurements do not readily yield quantitative information on FRET efficiency, they are sensitive to the experimental settings and require careful image analysis. Alternatively, fluorescence lifetime imaging microscopy (FLIM) can be used to calculate FRET efficiencies from the donor lifetime in the presence or absence of the acceptor [211].

The molecular tension sensors can be divided into two categories, those that are genetically engineered and expressed within living cells (genetically encoded molecular tension sensors, GETS) and those that are anchored to a surface to probe cellular receptor forces at the interface between living cells and their external ligands (immobilized tension sensors) [212].

\section{a. Number of cells in an experiment}


Analysis was performed by using measurements from a minimum of 10 cells at each condition [209].

\section{b. Typical force range}

As FRET force sensors measure the tension built up in single molecules, the overall adhesion force of the cell cannot be simply determined on the basis of FRET microscopy. FRET-based tension sensors provide piconewton $(\mathrm{pN})$ sensitivity within cells [210]. GETS are limited to the detection of forces within the range of 1 to $7 \mathrm{pN}$ [212]. In 2010, Grashoff et al. designed a tension sensor module (TSMod) resolving forces lower than $6 \mathrm{pN}$. The talin, a molecule that connects integrin receptors with the actin cytoskeleton through multiple interaction sites experiences mechanical forces of $\sim 7-10 \mathrm{pN}$ [210]. The tension across vinculin in stationary focal adhesions (FAs) was measured to be $\sim 2.5 \mathrm{pN}$ [50],[212]. In the last years, TSMod-s gained popularity [50] and have been used to determine tension across the adhesion protein vinculin [50],[213], cadherins [214],[215],[216], PECAM-1 [216], spectrin [217] or the glycoprotein MUC-1 [217].

Immobilization of molecular tension sensors to a solid support allows forces between cell membrane receptors and their extracellular ligands to be investigated. Integrin receptors exert an adhesion force of 1-5 pN to their ligands [218].

\section{c. Experiment duration}

$\sim 20 \min [209]$.

\section{d. Advantages}

Nanoscale interactions can be detected on the basis of the FRET [219] signal. FRET can be applied as a molecular force sensor built into single biomolecules. Genetic insertion of such a tension sensor module into the protein of interest and the expression of the resulting construct in cells allows the analysis of molecular forces in living cells [211]. It allows the measurement of single molecule reaction trajectories from about 1 millisecond to several minutes [220], [221].

FRET does not require mechanical perturbation of cells, which could alter cellular traction and adhesion forces. FRET can study how cells manipulate the ligands to which they adhere, and simultaneously determine cellular traction forces without perturbing the adhesion events [209]. 
A fundamental advantage of the technique is to measure the internal distance in the molecular frame rather than in the laboratory frame and hence it is largely immune to instrumental noise and drift [220].

The technique is adaptable to a wide variety of instrumentations, including fluorescence spectroscopes, conventional, total internal reflection (TIRF), confocal microscopes, and FACS [219].

\section{e. Disadvantages}

Artificial molecular force sensors are needed to be constructed and built into the cellular system, in most cases into a specific protein. Practically only one (or very few) protein type(s) can be measured in an experiment. Thus the overall cellular traction or adhesion force exerted by a large number of different proteins cannot be determined. The selection of an appropriate elastic molecular element of the force sensor is critical. The elastic linker has to be short or the increase in linker length has to be sufficiently large so that the applied tension can be observed as a change in FRET efficiency [211],[212]. FRET requires spectrally matched fluorophores. An ideal fluorophore for single molecule studies must be bright, photostable, small and water soluble. A problem inherent to any molecular force sensor is that its insertion can interfere with the properties of the host protein, and the host protein can interfere with the function of the force sensor [50].

\section{f. Main applications}

FRET can be used as a molecular ruler to monitor the nanometer scale displacements between adhesion ligands, and the corresponding traction force between integrin receptors and adhesion ligands [209]. It has been applied to quantitatively analyze the parameters of cell interactions with both 2- and 3-dimensional adhesion substrates [209],[219]. It is widely used to study intermolecular interactions [205],[222],[223]. The number of bonds between RGD and integrin receptors can be estimated in a 3D synthetic ECM [224]. Functionalization of the flagelliform peptide with organic dyes and RGD-ligands allows the estimation of force across single integrin receptors [218]. A FRET-based biosensor can follow the distribution of RhoA and Rac1 activities during cell-cell adhesion [225]. FRET can be used to explore the role of mechanical forces across proteins including actin-binding proteins and cell adhesion molecules like 
cadherin, PECAM-1 [216] and vinculin [50] in cellular systems. This tool may help to develop appropriate synthetic matrices useful for tissue engineering or cell-based therapies [209].

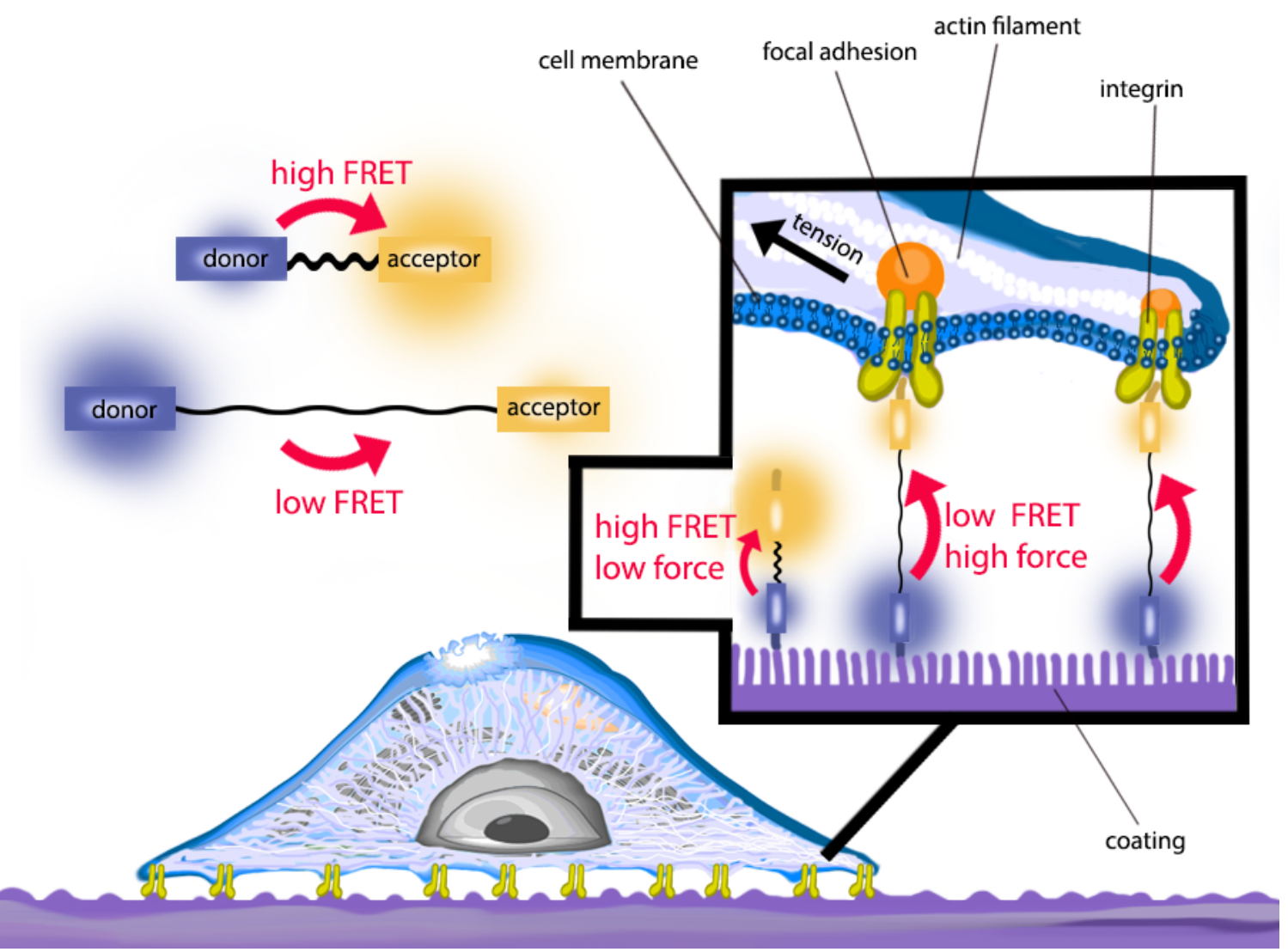

Fig.16 Schematic illustration of the operation of FRET force sensors. The method relies on the non-radiative energy transfer between two fluorophores. The emitted fluorescence of the donor molecule is quenched by the vicinity of the acceptor. Thus their distance can be calculated from the fluorescent signal. Binding a donor and an acceptor to both ends of an elastic biological polymer (such as a protein) allows to monitor the end to end distance of the polymer, which in turn characterizes the force exerted on the molecule. The technique is especially suited for the investigation of adhesion molecules such as integrins and actin binding cytoskeletal proteins.

\section{Summary}

Current review provides a guide to choose the appropriate technique for the measurement of cell adhesion in vitro. Most important parameters to be considered are the i) number of cells to be measured, ii) range of the adhesion force, iii) duration of the experiment. We identify the major advantages and disadvantages of each method. We propose that the combination of a 
simple cost effective method to gain data of the average behavior of a larger cell population and an advanced technique for single cell targeting can be a good strategy to obtain powerful data for biological and biophysical model development.

We also pointed out that the preparation of the adhesive surface for subsequent cellular studies has a crucial importance [22],[23]. Masking (blocking) the surface area not covered by specific biomolecules is a prerequisite for relevant results cleansed from the contribution of non-specific cell adhesion on glass, plastic or other artificial substrates [26],[30],[32],[33]. Thus we collected relevant examples and emphasized the importance of carefully controlling and pre-testing the surface chemistry. 


\begin{tabular}{|c|c|c|c|c|c|c|}
\hline Method & $\begin{array}{c}\text { a) } \\
\text { Number of } \\
\text { cells in an } \\
\text { experiment }\end{array}$ & $\begin{array}{c}\text { b) } \\
\text { Typical } \\
\text { range of } \\
\text { shear stress }\end{array}$ & $\begin{array}{c}\text { c) } \\
\text { Experiment } \\
\text { duration }\end{array}$ & $\begin{array}{c}\text { d) } \\
\text { Advantages }\end{array}$ & e) Disadvantages & $\begin{array}{c}\text { f) } \\
\text { Main applications }\end{array}$ \\
\hline $\begin{array}{c}1.1 \\
\text { Centrifugal } \\
\text { assay }\end{array}$ & $\begin{array}{l}\text { large number } \\
\text { of adherent } \\
\text { cells [68] }\end{array}$ & $\begin{array}{l}1-2000 \mathrm{pN} \\
\text { shear stress } \\
{[31],[42],} \\
{[69],[70],[71]}\end{array}$ & $\begin{array}{l}5-10 \min \\
{[31],[42],} \\
{[69],[72]}\end{array}$ & $\begin{array}{l}\text { * Simplicity } \\
\text { * Widely available } \\
\text { setup } \\
\text { * No special } \\
\text { equipment required, } \\
\text { only common lab } \\
\text { instruments [42] }\end{array}$ & $\begin{array}{l}* \text { Not possible to } \\
\text { precisely determine } \\
\text { the force acting on the } \\
\text { cell } \\
* \text { Limited to weakly } \\
\text { adherent cells } \\
* \text { Limited to short- } \\
\text { term adhesion studies } \\
{[42]}\end{array}$ & $\begin{array}{l}* \text { Sensitive, } \\
\text { quantitative } \\
\text { measurement of weak } \\
\text { binding forces [68] } \\
* \text { Quantifying cell } \\
\text { adhesion on SAMs } \\
\text { [69] } \\
* \text { Quantifying cell } \\
\text { adhesion to specific } \\
\text { RGD-modified } \\
\text { substrates [31] }\end{array}$ \\
\hline $\begin{array}{l}1.2 \\
\text { Spinning } \\
\text { disk }\end{array}$ & $\begin{array}{l}\text { population of } \\
\text { cells in a } \\
\text { single } \\
\text { experiment } \\
{[76]}\end{array}$ & $\begin{array}{l}1-200 \mathrm{~Pa} \\
\text { shear stress } \\
{[74],[77]}\end{array}$ & $\begin{array}{l}5-10 \min \\
{[76],[77]}\end{array}$ & $\begin{array}{l}* \text { Applying a wide } \\
\text { range of stresses in a } \\
\text { single experiment [74] } \\
* \text { High stresses }\end{array}$ & $\begin{array}{l}\text { * Not compatible with } \\
\text { in situ microscopy, nor } \\
\text { with the direct } \\
\text { visualization of cells } \\
\text { [61] }\end{array}$ & $\begin{array}{l}* \text { Employing in more } \\
\text { fundamental } \\
\text { experiments [40],[75], } \\
{[77]}\end{array}$ \\
\hline $\begin{array}{c}1.3 \\
\text { Radial flow } \\
\text { chamber }\end{array}$ & $\begin{array}{l}\text { population of } \\
\text { cells in a } \\
\text { single } \\
\text { experiment } \\
{[42],[79],[80]}\end{array}$ & $\begin{array}{l}<20 \mathrm{~Pa} \text { shear } \\
\text { stress [42] }\end{array}$ & $\begin{array}{l}5 \min \\
{[79],[81],} \\
{[83],[84]}\end{array}$ & $\begin{array}{l}* \text { Flexible } \\
* \text { Direct visualization } \\
\text { of cells } \\
* \text { In situ observation of } \\
\text { cell detachment } \\
\text { [79],[83] }\end{array}$ & $\begin{array}{l}* \text { Limited to weak } \\
\text { adhesion forces [81] }\end{array}$ & $\begin{array}{l}* \text { In situ detachment of } \\
\text { fibroblasts [79],[81] } \\
* \text { Determination of the } \\
\text { adhesive nature of } \\
\text { modified substrates } \\
{[79],[82],[86]}\end{array}$ \\
\hline $\begin{array}{c}1.4 \\
\text { Parallel } \\
\text { plate flow } \\
\text { chamber }\end{array}$ & $\begin{array}{l}* 300 \text { cells/ } \\
\text { experimental } \\
\text { group/ } \\
\text { experiment } \\
{[92]} \\
* 100-1,000 \\
\text { cells/mm }{ }^{2} \\
{[88],[91],[92]}\end{array}$ & $\begin{array}{l}*<20 \mathrm{~Pa}, \\
\text { shear stress } \\
{[42]} \\
* 1-25 \mathrm{~Pa} \\
{[89],[90]} \\
{[92],[93]}\end{array}$ & $\begin{array}{l}\text { A few sec- } \\
210 \min [89], \\
{[90],[92],} \\
{[93],[94]}\end{array}$ & $\begin{array}{l}* \text { Simplicity [95] } \\
* \text { Well-characterized } \\
\text { fluid flow field [89] } \\
* \text { Direct visualization } \\
\text { of cells [94] } \\
* \text { It can monitor cell } \\
\text { trajectories, speed and } \\
\text { adhesion. Motion of } \\
\text { spherical cells in the } \\
\text { flow can be calculated. } \\
\text { [91] }\end{array}$ & $\begin{array}{l}*>200 \mu \mathrm{m} \text { channel } \\
\text { height in most PPFC } \\
\text { limiting the cellular } \\
\text { adhesion force that can } \\
\text { be measured [61] }\end{array}$ & $\begin{array}{l}* \text { Determining the } \\
\text { adhesion strength of } \\
\text { fibroblast cells to } \\
\text { various substrates [89] } \\
* \text { Investigation of cell } \\
\text { retention, morphology } \\
\text { and migration as a } \\
\text { function of shear stress } \\
\text { and of adhesion time } \\
\text { [88] }\end{array}$ \\
\hline $\begin{array}{l}1.5 \\
\text { Microfluidic } \\
\text { rectangular } \\
\text { channels }\end{array}$ & $\begin{array}{l}* \sim 100 \text { cells/ } \\
\text { experiment } \\
{[102]} \\
* \text { Number of } \\
\text { analyzed } \\
\text { cells: } 100- \\
1,000[61], \\
{[100],[101],[1} \\
02]\end{array}$ & $\begin{array}{l}\text { Several } \\
\text { hundred Pa } \\
{[61],[101]}\end{array}$ & $\begin{array}{l}10-15 \min \\
{[61],[101]}\end{array}$ & $\begin{array}{l}* \text { Direct visualization } \\
\text { of cells [100] } \\
* \text { It can capture the } \\
\text { cell detachment } \\
* \text { Wide range of } \\
\text { adhesion forces can be } \\
\text { measured } \\
* \text { High-throughput } \\
\text { [61] } \\
* \text { Simple } \\
\text { experimental setup }\end{array}$ & $\begin{array}{l}* \text { Sustained flow } \\
\text { affects the } \\
\text { cytoskeleton and the } \\
\text { morphology of cells } \\
\text { attached to the surface. } \\
\text { Cells become } \\
\text { elongated in the } \\
\text { direction of the flow } \\
\text { being an apparent side } \\
\text { effect of the } \\
\text { measurement [101] }\end{array}$ & $\begin{array}{l}* \text { Investigating the } \\
\text { relationship between } \\
\text { adhesion strength and } \\
\text { cell geometry [101] }\end{array}$ \\
\hline
\end{tabular}

Table 1. Centrifugal and shear flow assays. 


\begin{tabular}{|c|c|c|c|c|c|c|}
\hline Method & $\begin{array}{c}\text { a) } \\
\text { Number of } \\
\text { cells in an } \\
\text { experiment }\end{array}$ & $\begin{array}{c}\text { b) } \\
\text { Typical } \\
\text { force range }\end{array}$ & $\begin{array}{c}\text { c) } \\
\text { Experiment } \\
\text { duration }\end{array}$ & d) Advantages & e) Disadvantages & $\begin{array}{c}\text { f) } \\
\text { Main applications }\end{array}$ \\
\hline $\begin{array}{c}2.1 \\
\text { Step pressure } \\
\text { technique }\end{array}$ & $\begin{array}{l}\sim 10 \text { pairs of } \\
\text { cells [109] }\end{array}$ & $\begin{array}{l}* \mathrm{Sc} \\
\text { represents the } \\
\text { adhesion } \\
\text { strength; } \\
\mathrm{Sc}=1.5 \\
\mathrm{nN} / \mu \mathrm{m}^{2} ; \\
744 \mathrm{nN} \\
\text { separation } \\
\text { force } \\
{[46],[47]} \\
* \text { Difficult to } \\
\text { measure the } \\
\text { exact contact } \\
\text { area between } \\
\text { the cells }\end{array}$ & $\begin{array}{l}* \text { Cells are } \\
\text { brought into } \\
\text { contact for } \\
\sim 10 \text { sec }[110] \\
* \text { Force } \\
\text { measurement } \\
\text { between two } \\
\text { cells for } 120 \\
\text { min [47] }\end{array}$ & $\begin{array}{l}* \text { Cell-cell contact } \\
\text { area and contact time } \\
\text { can be controlled } \\
{[46],[110]} \\
* \text { Measures cell } \\
\text { adhesion force directly } \\
{[46]}\end{array}$ & $\begin{array}{l}\text { * Low throughput, } \\
\text { manual measurement }\end{array}$ & $\begin{array}{l}* \text { Measuring the } \\
\text { adhesion force } \\
\text { between two similar or } \\
\text { different single cells in } \\
\text { vitro [47] }\end{array}$ \\
\hline $\begin{array}{c}2.2 \\
\text { Biomembrane } \\
\text { force probe }\end{array}$ & $\begin{array}{l}1 \text { cell/ } \\
\text { experiment }\end{array}$ & $\begin{array}{ll}\text { Vertical } \\
\text { mode: } \\
0.2-0.5 \\
\text { pN } \\
\text { Horizon } \\
\text { tal } \\
\text { mode: } \\
1-10 \mathrm{pN} \\
{[112]}\end{array}$ & $N A$ & $\begin{array}{l}* \text { Adjustable loading } \\
\text { rate of the force [46] } \\
* \text { Sub-pN force and } \\
\text { nanometer scale } \\
\text { displacement } \\
\text { resolution [46] } \\
* \text { Gentle measurement } \\
\text { minimally altering the } \\
\text { cytoskeleton [111] } \\
* \text { Can detect weak } \\
\text { adhesive bonds }\end{array}$ & $\begin{array}{l}* \text { The resolution of } \\
\text { probe movement is not } \\
\text { as good as in AFM } \\
\text { [111] }\end{array}$ & $\begin{array}{l}* \text { Studying receptor- } \\
\text { ligand binding [46] }\end{array}$ \\
\hline $\begin{array}{c}2.3 \\
\text { Micropipette } \\
\text { aspiration } \\
\text { technique }\end{array}$ & $\begin{array}{l}1 \text { cell/ } \\
\text { experiment }\end{array}$ & $\begin{array}{l}* \text { A force } \\
\text { lower than } \\
10-20 \mathrm{pN}[46] \\
* \text { Hundreds } \\
\text { of } \mathrm{nN} \text { forces } \\
{[46]}\end{array}$ & $\begin{array}{l}\text { User- } \\
\text { specified } \\
\text { length of time } \\
(2 \mathrm{~s} \text { and } 1 \\
\text { min) }[120]\end{array}$ & $\begin{array}{l}\text { } \\
* \text { Simplicity } \\
* \text { Measures the force } \\
\text { without attaching cells } \\
\text { onto a solid surface } \\
* \text { Can study cell-cell } \\
\text { interactions directly } \\
* \text { Higher forces than } \\
\text { with optical tweezers } \\
* \text { Versatility [46] }\end{array}$ & $\begin{array}{l}* \text { Alignment of probe } \\
\text { and cell: one of the } \\
\text { cells (or probe) has to } \\
\text { fit snugly inside the } \\
\text { pipette } \\
* \text { Cannot measure } \\
<10-20 \mathrm{pN} \text { forces } \\
\text { precisely when the } \\
\text { diameter of the pipette } \\
\text { is } \sim 10 \mu \mathrm{m} \text { [107] } \\
* \text { Low force } \\
\text { sensitivity } \\
* \text { Evaporation in the } \\
\text { chamber is technically } \\
\text { challenging [118] } \\
* \text { Severe cell } \\
\text { deformation prior to } \\
\text { detachment }\end{array}$ & $\begin{array}{l}* \text { Measuring } \\
\text { viscoelastic properties } \\
\text { of soft cells } \\
* \text { Studying } \\
\text { mechanical properties } \\
\text { of living cells [118] }\end{array}$ \\
\hline $\begin{array}{c}2.4 \\
\text { Computer } \\
\text { controlled } \\
\text { micropipette }\end{array}$ & $\begin{array}{l}\text { Hundreds of } \\
\text { cells: total } \\
\text { number of } \\
\text { human } \\
\text { immune cells } \\
\text { probed by the } \\
\text { micropipette } \\
\text { was 200-600 } \\
\text { [23] }\end{array}$ & $0-2 \mu \mathrm{N}[23]$ & $\sim 30 \min [23]$ & $\begin{array}{l}* \text { Relatively high } \\
\text { throughput [23], } \\
\text { especially when } \\
\text { compared to AFM or } \\
\text { FluidFM } \\
* \text { Direct visualization } \\
\text { of cells [23] } \\
* \text { Higher sensitivity } \\
\text { and less side-effect } \\
\text { than in microfluidic } \\
\text { shear stress channel } \\
\text { [23] }\end{array}$ & $\begin{array}{l}* \text { Hydrodynamic } \\
\text { simulations are needed } \\
\text { to convert the } \\
\text { experimental vacuum } \\
\text { value to hydrodynamic } \\
\text { lifting force [23] }\end{array}$ & $\begin{array}{l}* \text { Probing single cell } \\
\text { interactions with } \\
\text { specific } \\
\text { macromolecules [23] } \\
* \text { Studying cell-cell } \\
\text { interactions [124] }\end{array}$ \\
\hline
\end{tabular}

Table 2. Micropipette manipulation assays. 


\begin{tabular}{|c|c|c|c|c|c|c|}
\hline Method & $\begin{array}{c}\text { a) } \\
\text { Number of } \\
\text { cells in an } \\
\text { experiment }\end{array}$ & $\begin{array}{c}\text { b) } \\
\text { Typical } \\
\text { force } \\
\text { range }\end{array}$ & $\begin{array}{c}\text { c) } \\
\text { Experiment } \\
\text { duration }\end{array}$ & $\begin{array}{c}\text { d) } \\
\text { Advantages }\end{array}$ & $\begin{array}{c}\text { e) } \\
\text { Disadvantages }\end{array}$ & $\begin{array}{c}\text { f) } \\
\text { Main applications }\end{array}$ \\
\hline $\begin{array}{c}3 . \\
\text { Optical } \\
\text { tweezers }\end{array}$ & $\begin{array}{l}1 \text { cell/ } \\
\text { experiment }\end{array}$ & $\begin{array}{l}0.1-100 \\
\mathrm{pN} \\
{[127]}\end{array}$ & $\begin{array}{l}\text { Manipulations } \\
\text { of a cell takes } \\
\text { less than } 15 \mathrm{~min} \\
{[133]}\end{array}$ & 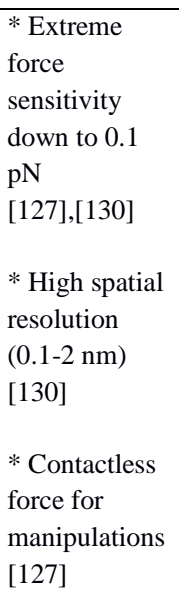 & $\begin{array}{l}* \text { The range of } \\
\text { applied forces is } \\
\text { limited to max. } \\
100 \mathrm{pN}[130] \\
* \text { Photodamage } \\
\text { and thermal } \\
\text { damage [127], } \\
\text { [135] }\end{array}$ & $\begin{array}{c}\text { * Interaction and binding } \\
\text { assays [130], [132], } \\
{[141],[142],} \\
{[143],[144],[226]} \\
* \text { Tethered assay } \\
{[127],[132],[145],[146]}\end{array}$ \\
\hline
\end{tabular}

Table 3. Optical tweezers. 


\begin{tabular}{|c|c|c|c|c|c|c|}
\hline Method & $\begin{array}{l}\text { a) } \\
\text { Number of } \\
\text { cells in an } \\
\text { experiment }\end{array}$ & $\begin{array}{c}\text { b) } \\
\text { Typical } \\
\text { force range }\end{array}$ & $\begin{array}{c}\text { c) } \\
\text { Experiment } \\
\text { duration }\end{array}$ & $\begin{array}{c}\text { d) } \\
\text { Advantages }\end{array}$ & $\begin{array}{c}\text { e) } \\
\text { Disadvantages }\end{array}$ & $\begin{array}{c}\text { f) } \\
\text { Main applications }\end{array}$ \\
\hline $\begin{array}{c}\mathbf{4 . 1} \\
\text { Atomic } \\
\text { force } \\
\text { microscopy } \\
4.1 .1 \\
\text { normal } \\
\text { force }\end{array}$ & $\begin{array}{l}* \text { a few }(1-5) \\
\text { cell measured } \\
\text { per condition } \\
{[160]}\end{array}$ & $\begin{array}{l}* \mathrm{nN}-\mathrm{pN} \\
\text { forces [161] } \\
* \text { Minimum } \\
\text { force: } 50-100 \\
\mathrm{pN} \\
* \text { At } 100- \\
1,000 \mathrm{pN} \\
\text { force, the } \\
\text { biological } \\
\text { sample is } \\
\text { reversibly } \\
\text { deformed, } \\
\text { above this } \\
\text { value } \\
\text { irreversibly } \\
\text { deformed } \\
\text { [163],[164], } \\
\text { [165] } \\
* \text { AFM-based } \\
\text { SCFS: } 5 \text { pN- } \\
100 \mathrm{nN} \text { [149] }\end{array}$ & $\begin{array}{l}* \text { Chemical } \\
\text { functionalization of } \\
\text { the cantilever: } 1 \mathrm{~h} \\
* \sim 10 \text { min needed } \\
\text { for proper cell- } \\
\text { cantilever interaction } \\
* \text { Relatively short } \\
\text { contact times (msec- } \\
\text { 20min) }[43],[170]\end{array}$ & $\begin{array}{l}\text { * Spatial and force } \\
\text { resolution is high } \\
{[148]} \\
* \text { pN force sensitivity } \\
\text { *nm positioning } \\
\text { accuracy } \\
\text { * Can map and } \\
\text { analyze individual } \\
\text { receptors with } \\
\text { nanoscale lateral } \\
\text { resolution [148] }\end{array}$ & $\begin{array}{l}* \text { Costly method } \\
\text { [43],[48],[149] } \\
* \text { Time-consuming } \\
\text { [161],[174] } \\
* \text { Requires a separate } \\
\text { calibrated and } \\
\text { functionalized } \\
\text { cantilever for each } \\
\text { cell [43],[48],[149] } \\
* \text { Chemical } \\
\text { attachment of the cell } \\
\text { to the cantilever can } \\
\text { change the } \\
\text { physiology of the cell } \\
\text { [161],[174] } \\
* \text { High number of } \\
\text { detachment force- } \\
\text { distance curves need } \\
\text { to be measured to } \\
\text { gain reliable statistics } \\
\text { [43],[170] } \\
* \text { Limited to } \\
\text { relatively short } \\
\text { contact times [43] }\end{array}$ & $\begin{array}{l}\text { * Investigation of cell } \\
\text { adhesion and the } \\
\text { interactions between } \\
\text { specific ligand- } \\
\text { receptor pairs [149] } \\
\text { * Studying the } \\
\text { dynamic formation of } \\
\text { cellular adhesion } \\
\text { * Measuring cell-cell } \\
\text { and cell-substrate } \\
\text { adhesion [43] } \\
\text { * Extends its use } \\
\text { from quantitatively } \\
\text { characterizing whole- } \\
\text { cell adhesion down to } \\
\text { single receptor-ligand } \\
\text { interactions [43] }\end{array}$ \\
\hline $\begin{array}{c}4.1 \\
\text { Atomic } \\
\text { force } \\
\text { microscopy } \\
4.1 .2 \\
\text { Tangential/ } \\
\text { lateral force }\end{array}$ & $\begin{array}{l}200-300 \\
\text { cells }[2]\end{array}$ & $\begin{array}{l}10-100 \mathrm{nN} \\
{[2],[176]}\end{array}$ & $\begin{array}{l}\text { Adhesion time:10- } \\
90 \text { min [2] }\end{array}$ & $\begin{array}{l}* \text { Much lower force } \\
\text { is sufficient to detach } \\
\text { a particle than a } \\
\text { normal force } \\
{[177],[178]}\end{array}$ & $\begin{array}{l}\text { * Interpretation of } \\
\text { the data is not } \\
\text { straightforward [2] } \\
* \text { The measured } \\
\text { force depends on } \\
\text { experimental details } \\
\text { (shape of the tip, } \\
\text { scanning speed, } \\
\text { torsional cantilever } \\
\text { spring constant) } \\
\text { [78],[179] }\end{array}$ & $\begin{array}{l}* \text { Measuring the } \\
\text { adhesion force of } \\
\text { protein-covered silica } \\
\text { spheres adsorbed to } \\
\text { polystyrene surfaces } \\
\text { [180] } \\
\text { * Measuring the } \\
\text { adhesion force of } \\
\text { individual cervix cells } \\
\text { to various substrates } \\
\text { [2] }\end{array}$ \\
\hline $\begin{array}{c}4.2 \\
\text { Fluidic } \\
\text { force } \\
\text { microscopy }\end{array}$ & $\begin{array}{l}* \text { Up to } 200 \\
\text { yeast and } 20 \\
\text { mammalian } \\
\text { cells/probe } \\
* \text { Studying } \\
\sim 10 \text { cells in } \\
\text { half an hour }\end{array}$ & $\begin{array}{l}500 \mathrm{pN}-1.6 \\
\mu \mathrm{N}[48]\end{array}$ & $\begin{array}{l}* \text { Carrying out } \sim 10- \\
\text { times more } \\
\text { experiments than } \\
\text { conventional AFM } \\
* \text { Only a few } \\
\text { minutes to target, } \\
\text { immobilize, and } \\
\text { release the cell as } \\
\text { well as to change the } \\
\text { cantilever position to } \\
\text { the next cell }[48]\end{array}$ & $\begin{array}{l}* \text { Directly measures } \\
\text { the adhesion force } \\
* \sim 10 \text { times higher } \\
\text { throughput than } \\
\text { conventional AFM } \\
\text { can provide [48] } \\
* \text { Increased maximum } \\
\text { force as compared to } \\
\text { AFM [43] } \\
* \text { No need for } \\
\text { chemical } \\
\text { functionalization of } \\
\text { the cantilever [183] }\end{array}$ & $\begin{array}{l}* \text { Throughput is lower } \\
\text { than that of the } \\
\text { automated } \\
\text { micropipette } \\
\text { * Microfabricated } \\
\text { cantilevers come with } \\
\text { a high measurement } \\
\text { cost } \\
* \text { Cells come into } \\
\text { direct contact with the } \\
\text { cantilever potentially } \\
\text { perturbing or } \\
\text { damaging cells }\end{array}$ & $\begin{array}{l}* \text { Monitoring the } \\
\text { adhesion of single } \\
\text { cells to specific } \\
\text { substrates [48] } \\
\text { *Microinjection of } \\
\text { cells [185] } \\
\text { *Microprinting } \\
\text { [186],[187],[188] }\end{array}$ \\
\hline
\end{tabular}

Table 4. Atomic force and fluidic force microscopy. 


\begin{tabular}{|c|c|c|c|c|c|c|}
\hline Method & $\begin{array}{c}\text { a) } \\
\text { Number of } \\
\text { cells in an } \\
\text { experiment }\end{array}$ & $\begin{array}{c}\text { b) } \\
\text { Typical } \\
\text { force range }\end{array}$ & $\begin{array}{c}\text { c) } \\
\text { Experiment } \\
\text { duration }\end{array}$ & $\begin{array}{c}\text { d) } \\
\text { Advantages }\end{array}$ & $\begin{array}{c}\text { e) } \\
\text { Disadvantages }\end{array}$ & $\begin{array}{c}\text { f) } \\
\text { Main applications }\end{array}$ \\
\hline $\begin{array}{c}5.1 \\
\text { Cell } \\
\text { traction } \\
\text { force } \\
\text { microscopy }\end{array}$ & $\begin{array}{l}1-5 \text { in single } \\
\text { cell } \\
\text { experiments, } \\
\text { several } \\
\text { hundreds of } \\
\text { cells in } \\
\text { collective } \\
\text { migration } \\
\text { studies }\end{array}$ & $\begin{array}{l}* \text { Depending } \\
\text { on the } \\
\text { elasticity of } \\
\text { the substrate, } \\
\text { which can be } \\
\text { tuned in the } \\
\text { physiological } \\
\text { range [189] } \\
* \text { Not } \\
\text { possible to } \\
\text { resolve small } \\
\text { forces if the } \\
\text { overall } \\
\text { magnitude of } \\
\text { traction is } \\
\text { high }\end{array}$ & $\begin{array}{l}* \text { The } \\
\text { imaging stage } \\
\text { is only a few } \\
\text { minutes } \\
* \text { Image } \\
\text { analysis and } \\
\text { deconvolution } \\
\text { of the traction } \\
\text { field is time } \\
\text { consuming } \\
{[193]}\end{array}$ & $\begin{array}{l}* \text { Single cell } \\
\text { measurements } \\
* \text { Remaining cells } \\
\text { unperturbed } \\
* \text { High resolution } \\
\text { mapping of cell- } \\
\text { exerted forces } \\
* \text { Following the } \\
\text { evolution of traction } \\
\text { through time, although } \\
\text { practically with a poor } \\
\text { temporal resolution } \\
* \text { Using a confocal } \\
\text { microscope, all } \\
\text { components (x,y,z) of } \\
\text { forces exerted on a 2D } \\
\text { substrate can be } \\
\text { attained (2.5D CTFM } \\
\text { [192] } \\
* \text { Using confocal } \\
\text { microscopy, the } \\
\text { traction forces of a } \\
\text { cell embedded in a 3D } \\
\text { matrix can be } \\
\text { determined (3D } \\
\text { CTFM) [196] }\end{array}$ & $\begin{array}{l}* \text { Extremely low } \\
\text { throughput } \\
* \text { Image analysis and } \\
\text { the deconvolution of } \\
\text { the traction field is } \\
\text { time consuming } \\
\text { [193],[194] } \\
* \text { The traction field } \\
\text { may be very sensitive } \\
\text { to noises [193],[194] } \\
* 2.5 D \text { and 3D CTFM } \\
\text { requires a confocal } \\
\text { microscope [196] } \\
* 3 D \text { CTFM is in its } \\
\text { infancy }\end{array}$ & $\begin{array}{l}* \text { Mapping the 2D } \\
\text { and 2.5D traction field } \\
\text { of [189] } \\
\text { - individual cells } \\
\text { [199],[200] } \\
\text { - cell aggregates [201] } \\
\text { - migrating single } \\
\text { cells [203] } \\
\text { - a layer of } \\
\text { collectively migrating } \\
\text { cells [204] } \\
* \text { Mapping the } \\
\text { traction field of cells } \\
\text { embedded in a 3D } \\
\text { matrix [196], [197] } \\
* \text { Correlating } \\
\text { adhesion force with } \\
\text { local actin density or } \\
\text { with the } \\
\text { size/molecular } \\
\text { composition of } \\
\text { adhesion complexes } \\
\text { [191] }\end{array}$ \\
\hline $\begin{array}{c}5.2 \\
\text { FRET force } \\
\text { sensors }\end{array}$ & $\begin{array}{l}\text { Minimum of } \\
10 \text { cells at } \\
\text { each } \\
\text { condition } \\
{[209]}\end{array}$ & $\begin{array}{l}\text { pN sensitivity } \\
{[210]}\end{array}$ & $\begin{array}{l}\sim 20 \mathrm{~min} \\
{[209]}\end{array}$ & $\begin{array}{l}* \text { Can detect protein- } \\
\text { protein nanoscale } \\
\text { interactions [219] } \\
* \text { Does not require } \\
\text { mechanical } \\
\text { perturbation or } \\
\text { stimulation of cells } \\
\text { [209] } \\
* \text { Measures the force } \\
\text { exerted by individual } \\
\text { molecules [220] } \\
* \text { Can be tracked in } \\
\text { time [221] }\end{array}$ & $\begin{array}{l}* \text { Artificial molecular } \\
\text { force sensors are } \\
\text { needed to be built into } \\
\text { the cellular system (a } \\
\text { specific protein) } \\
* \text { The selection of an } \\
\text { appropriate elastic } \\
\text { molecular element of } \\
\text { the force sensor is } \\
\text { critical [211],[212] } \\
* \text { Requires spectrally } \\
\text { matched fluorophores } \\
\text { in the force sensor } \\
\text { [212], [220] } \\
* \text { High sensitivity } \\
\text { camera is needed for } \\
\text { imaging } \\
* \text { Requires data } \\
\text { analysis algorithm to } \\
\text { determine FRET [211] }\end{array}$ & $\begin{array}{l}* \text { Exploring the role } \\
\text { of mechanical forces } \\
\text { built up in proteins } \\
\text { [50],[216] } \\
* \text { Estimating the force } \\
\text { across single integrin } \\
\text { receptors [218] } \\
* \text { Quantifying } \\
\text { conformational } \\
\text { dynamics in single } \\
\text { molecules [212] } \\
* \text { Measuring the } \\
\text { parameters of cell } \\
\text { interactions with 2-3D } \\
\text { adhesion substrates } \\
\text { [209],[219] }\end{array}$ \\
\hline
\end{tabular}

Table 5. Cell traction force microscopy and FRET force sensors. 


\section{Acknowledgment}

\section{Funding sources}

This work was supported by the National Research, Development and Innovation Office (grant numbers: PD 124559 for R. U. S., KH_17, KKP 129936 for R. H. ), “Lendület” Program of the Hung. Acad. Sci., ERC_HU for R. H., MedInProt grant of the Hung. Acad. Sci., Bolyai Scholarship for B. S.

\section{Declaration of interest}

B.S. is a founder of CellSorter Company for Innovations, a startup company that developed the computer-controlled micropipette device. 


\section{References}

[1] Bachir AI, Horwitz AR, Nelson WJ, Bianchini JM. Cell adhesions: ActinBased Modules that Mediate Cell- Extracellular Matrix and Cell-Cell Interactions. Cold Spring Harb Perspect Biol 2017;9:a023234. doi:10.1101/cshperspect.a023234.

[2] Sagvolden G, Giaever I, Pettersen EO, Feder J. Cell adhesion force microscopy. Proc Natl Acad Sci U S A 1999;96:471-6. doi:10.1073/pnas.96.2.471.

[3] Iwamoto D V, Calderwood DA. Regulation of integrin-mediated adhesions. Curr Opin Cell Biol 2015;36:41-7. doi:10.1016/j.ceb.2015.06.009.

[4] Sun Z, Guo SS, Fässler R. Integrin-mediated mechanotransduction. J Cell Biol 2016;215:445-56. doi:10.1083/JCB.201609037.

[5] Leckband DE, de Rooij J. Cadherin Adhesion and Mechanotransduction. Annu Rev Cell Dev Biol 2014;30:291-315. doi:10.1146/annurev-cellbio100913-013212.

[6] Changede R, Sheetz M. Integrin and cadherin clusters: A robust way to organize adhesions for cell mechanics. BioEssays 2017;39:1-12. doi:10.1002/bies.201600123.

[7] Alberts B, Johnson A, Lewis J, Raff M, Roberts K, Walter P. Molecular biology of the cell, 5th Edition, Garland Science. vol. 19. New York: 2007.

[8] Keselowsky BG, García AJ. Quantitative methods for analysis of integrin binding and focal adhesion formation on biomaterial surfaces.

Biomaterials 2005;26:413-8. doi:10.1016/j.biomaterials.2004.02.050.

[9] Geiger B, Bershadsky A, Pankov R, Yamada KM. Transmembrane crosstalk between the extracellular matrix-cytoskeleton crosstalk. Nat Rev Mol Cell Biol 2002;2:793-805. doi:10.1038/35099066.

[10] Lehenkari PP, Horton MA. Single integrin molecule adhesion forces in intact cells measured by atomic force microscopy. Biochem Biophys Res Commun 1999;259:645-50. doi:10.1006/bbrc.1999.0827.

[11] Lee IS, Marchant RE. Force measurements on platelet surfaces with high spatial resolution under physiological conditions. Colloids Surfaces B Biointerfaces 2000;19:357-65. doi:10.1016/S0927-7765(00)00144-2.

[12] Deshpande VS, McMeeking RM, Evans AG. A model for the contractility 
of the cytoskeleton including the effects of stress-fibre formation and dissociation. Proc R Soc A Math Phys Eng Sci 2007;463:787-815. doi:10.1098/rspa.2006.1793.

[13] Besser A, Schwarz US. Coupling biochemistry and mechanics in cell adhesion: A model for inhomogeneous stress fiber contraction. New $\mathbf{J}$ Phys 2007;9:425. doi:10.1088/1367-2630/9/11/425.

[14] Ingber DE. Cellular tensegrity: defining new rules of biological design that govern the cytoskeleton. J Cell Sci 1993;104:613-27.

[15] Cañadas P, Laurent VM, Oddou C, Isabey D, Wendling S. A cellular tensegrity model to analyse the structural viscoelasticity of the cytoskeleton. J Theor Biol 2002;218:155-73. doi:10.1006/yjtbi.3064.

[16] Ghaffari H, Saidi MS, Firoozabadi B. Biomechanical analysis of actin cytoskeleton function based on a spring network cell model. Proc Inst Mech Eng Part C J Mech Eng Sci 2017;0:1-16. doi:10.1177/0954406216668546.

[17] Schwarz US, Erdmann T, Bischofs IB. Focal adhesions as mechanosensors: The two-spring model. BioSystems 2006;83:225-32. doi:10.1016/j.biosystems.2005.05.019.

[18] Ley K, Laudanna C, Cybulsky MI, Nourshargh S. Getting to the site of inflammation: the leukocyte adhesion cascade updated. Nat Rev Immunol 2007;7:678-89. doi:10.1038/nri2156.

[19] Albelda SM. Role of integrins and other cell adhesion molecules in tumor progression and metastasis . J Tech Methods Pathol 1993;68:4-17.

[20] Rao CCG, Chianese D, Doyle GVG, Miller MC, Russell T, Sanders R, et al. Expression of epithelial cell adhesion molecule in carcinoma cells present in blood and primary and metastatic tumors. Int J Oncol 2005;27:49-57. doi:10.3892/ijo.27.1.49.

[21] Kobayashi H, Boelte KC, Lin PC. Endothelial cell adhesion molecules and cancer progression. Curr Med Chem 2007;14:377-86. doi:10.2174/092986707779941032.

[22] Orgovan N, Peter B, Bősze S, Ramsden JJ, Szabó B, Horvath R. Dependence of cancer cell adhesion kinetics on integrin ligand surface density measured by a high-throughput label-free resonant waveguide grating biosensor. Sci Rep 2014;4:4034. doi:10.1038/srep04034.

[23] Salánki R, Hős C, Orgovan, Norbert, Péter B, Sándor N, Bajtay Z, Erdei 
A, et al. Single Cell Adhesion Assay Using Computer Controlled Micropipette. PLoS One 2014;9:e111450. doi:10.1371/journal.pone.0111450.

[24] Trepat X, Wasserman MR, Angelini TE, Millet E, Weitz DA, Butler JP, et al. Physical forces during collective cell migration. Nat Phys 2009;5:42630. doi:10.1038/nphys 1269 .

[25] Legant WR, Choi CK, Miller JS, Shao L, Gao L, Betzig E, et al. Multidimensional traction force microscopy reveals out-of-plane rotational moments about focal adhesions. Proc Natl Acad Sci U S A 2013;110:8816. doi:10.1073/pnas.1207997110.

[26] Huang N, Michel R, Voros J, Textor M, Hofer R, Rossi A, et al. Poly(1lysine)-g-poly(ethylene glycol) Layers on Metal Oxide Surfaces: SurfaceAnalytical Characterization and Resistance to Serum and Fibrinogen Adsorption. Langmuir 2001;17:489-98. doi:10.1021/la000736.

[27] Roger M, Pasche S, Textor M, Castner DG. The Influence of PEG Architecture on Protein Adsorption and Conformation. Langmuir 2005;21:12327-12332. doi:10.1016/j.biotechadv.2011.08.021.Secreted.

[28] Faraasen S, Faraasen S, Vörös J, Vörös J, Csúcs G, Csúcs G, et al. Ligandspecific trageting of microspheres to phagocytes by surface modification with poly(1-lysine)-grafted PEG conjugate. Pharm Res 2003;20:237-46.

[29] Ogaki R, Zoffmann Andersen O, Jensen GV, Kolind K, Kraft DCE, Pedersen JS, et al. Temperature-induced ultradense PEG polyelectrolyte surface grafting provides effective long-term bioresistance against mammalian cells, serum, and whole blood. Biomacromolecules 2012;13:3668-77. doi:10.1021/bm301125g.

[30] VandeVondele S, Vörös J, Hubbell J. RGD-grafted poly-L-lysine-graft(polyethylene glycol) copolymers block non-specific protein adsorption while promoting cell adhesion. Biotechnol Bioeng 2003;82:784-90. doi:10.1002/bit.10625.

[31] Koo LY, Irvine DJ, Mayes AM, Lauffenburger D, Griffith LG. Coregulation of cell adhesion by nanoscale RGD organization and mechanical stimulus. J Cell Sci 2002;115:1423-33.

[32] Zhen G, Zurcher S, Falconnet D, Xu F, Kuennemann E, Textor M. NTAFunctionalized Poly(L-lysine)-g-Poly(Ethylene Glycol): A Polymeric Interface for Binding and Studying 6 His-tagged Proteins. 2005 IEEE Eng. Med. Biol. 27th Annu. Conf., vol. 1, 2005, p. 1036-8. 
doi:10.1109/IEMBS.2005.1616595.

[33] Hua B, Han KY, Zhou R, Kim H, Shi X, Abeysirigunawardena SC, et al. An improved surface passivation method for single-molecule studies. Nat Methods 2014;11:1233-6. doi:10.1038/nmeth.3143.

[34] Kovacs B, Patko D, Szekacs I, Orgovan N, Kurunczi S, Sulyok A, et al. Flagellin based biomimetic coatings: From cell-repellent surfaces to highly adhesive coatings. Acta Biomater 2016;42:66-76.

doi:10.1016/j.actbio.2016.07.002.

[35] Kovacs B, Patko D, Klein A, Kakasi B, Saftics A, Kurunczi S, et al. Bacteria repellent layer made of flagellin. Sensors Actuators B Chem 2018;257:839-45. doi:10.1016/j.snb.2017.11.027.

[36] Kovacs B, Saftics A, Biro A, Kurunczi S, Szalontai B, Kakasi B, et al. Kinetics and Structure of Self-Assembled Flagellin Monolayers on Hydrophobic Surfaces in the Presence of Hofmeister Salts: Experimental Measurement of the Protein Interfacial Tension at the Nanometer Scale. J Phys Chem C 2018;122:21375-86. doi:10.1021/acs.jpcc.8b05026.

[37] Kovacs N, Patko D, Orgovan N, Kurunczi S, Ramsden JJ, Vonderviszt F, et al. Optical anisotropy of flagellin layers: In situ and label-free measurement of adsorbed protein orientation using OWLS. Anal Chem 2013;85:5382-9. doi:10.1021/ac3034322.

[38] Khalili AA, Ahmad MR. A Review of cell adhesion studies for biomedical and biological applications. Int J Mol Sci 2015;16:18149-84. doi:10.3390/ijms160818149.

[39] Klebe RJ. Isolation of a collagen-dependent cell attachment factor. Nature 1974;250:248-51. doi:10.1038/250248a0.

[40] García AJ, Ducheyne P, Boettiger D. Quantification of cell adhesion using a spinning disc device and application to surface-reactive materials. Biomaterials 1997;18:1091-8. doi:10.1016/S0142-9612(97)00042-2.

[41] Kaplanski G, Farnarier C, Tissot O, Pierres A, Benoliel AM, Alessi MC, et al. Granulocyte-endothelium initial adhesion. Analysis of transient binding events mediated by E-selectin in a laminar shear flow. Biophys $\mathbf{J}$ 1993;64:1922-33. doi:10.1016/S0006-3495(93)81563-7.

[42] Christ K V, Turner KT. Methods to Measure the Strength of Cell Adhesion to Substrates. J Adhes Sci \&amp; Technol 2010;24:2027-58. doi:10.1163/016942410X507911. 
[43] Helenius J, Heisenberg C-P, Gaub HE, Muller DJ. Single-cell force spectroscopy. J Cell Sci 2008;121:1785-91. doi:10.1242/jcs.030999.

[44] Puech PH, Poole K, Knebel D, Muller DJ. A new technical approach to quantify cell-cell adhesion forces by AFM. Ultramicroscopy 2006;106:637-44. doi:10.1016/j.ultramic.2005.08.003.

[45] Hochmuth RM. Micropipette aspiration of living cells. J Biomech 2000;33:15-22. doi:10.1016/S0021-9290(99)00175-X.

[46] Shao J-Y, Xu G, Guo P. Quantifying cell-adhesion strength with micropipette manipulation: principle and application. Front Biosci 2004;9:2183-91. doi:10.2741/1386.

[47] Sung KL, Sung LA, Crimmins M, Burakoff SJ, Chien S. Determination of junction avidity of cytolytic T cell and target cell. Science 1986;234:14058. doi:10.1126/science.3491426.

[48] Potthoff E, Guillaume-Gentil O, Ossola D, Polesel-Maris J, LeibundGutLandmann S, Zambelli T, et al. Rapid and Serial Quantification of Adhesion Forces of Yeast and Mammalian Cells. PLoS One 2012;7:e52712. doi:10.1371/journal.pone.0052712.

[49] Roca-Cusachs P, Conte V, Trepat X. Quantifying forces in cell biology. Nat Cell Biol 2017;19:742-51. doi:10.1038/ncb3564.

[50] Grashoff C, Hoffman BD, Brenner MD, Zhou R, Parsons M, Yang MT, et al. Measuring mechanical tension across vinculin reveals regulation of focal adhesion dynamics. Nature 2010;466:263-6. doi:10.1038/nature09198.

[51] Ramsden JJ, Horvath R. Optical biosensors for cell adhesion. J Recept Signal Transduct 2009;29:211-23.

[52] Orgovan N, Salánki R, Sándor N, Bajtay Z, Erdei A, Szabó B, et al. In-situ and label-free optical monitoring of the adhesion and spreading of primary monocytes isolated from human blood: Dependence on serum concentration levels. Biosens Bioelectron 2014;54:339-44. doi:10.1016/j.bios.2013.10.076.

[53] Cottier K, Horvath R. Imageless microscopy of surface patterns using optical waveguides. Appl Phys B Lasers Opt 2008;91:319-27. doi:10.1007/s00340-008-2994-6.

[54] Peter B, Ungai-Salanki R, Szabó B, Nagy AG, Szekacs I, Bösze S, et al. High-Resolution Adhesion Kinetics of EGCG-Exposed Tumor Cells on 
Biomimetic Interfaces: Comparative Monitoring of Cell Viability Using Label-Free Biosensor and Classic End-Point Assays. ACS Omega 2018;3:3882-91. doi:10.1021/acsomega.7b01902.

[55] Peter B, Farkas E, Forgacs E, Saftics A, Kovacs B, Kurunczi S, et al. Green tea polyphenol tailors cell adhesivity of RGD displaying surfaces: Multicomponent models monitored optically. Sci Rep 2017;7:1-16. doi:10.1038/srep42220.

[56] Giebel KF, Bechinger C, Herminghaus S, Riedel M, Leiderer P, Weiland $\mathrm{U}$, et al. Imaging of cell/substrate contacts of living cells with surface plasmon resonance microscopy. Biophys J 1999;76:509-16. doi:10.1016/S0006-3495(99)77219-X.

[57] Lord MS, Modin C, Foss M, Duch M, Simmons A, Pedersen FS, et al. Monitoring cell adhesion on tantalum and oxidised polystyrene using a quartz crystal microbalance with dissipation. Biomaterials 2006;27:452937. doi:10.1016/j.biomaterials.2006.04.006.

[58] Dixon MC. Quartz Crystal Microbalance with Dissipation Monitoring: Enabling Real-Time Characterization of Biological Materials and Their Interactions. J Biomol Tech 2008;19:151-8.

[59] Modin C, Stranne A-L, Foss M, Duch M, Justesen J, Chevallier J, et al. QCM-D studies of attachment and differential spreading of preosteoblastic cells on Ta and Cr surfaces. Biomaterials 2006;27:1346-54. doi:10.1016/j.biomaterials.2005.09.022.

[60] Marx K, Zhou T, Schulze H, Braunhut SJ. A Quartz Crystal Microbalance cell biosensor: Detection of microtubule alterations in living cells at $\mathrm{nM}$ nocodazole concentrations. Biosens Bioelectron 16 2001;16:773-82.

[61] Christ K V., Williamson KB, Masters KS, Turner KT. Measurement of single-cell adhesion strength using a microfluidic assay. Biomed Microdevices 2010;12:443-55. doi:10.1007/s10544-010-9401-x.

[62] Walther BT, Ohman R, Roseman S. A quantitative assay for Intercellular Adhesion 1973;70:1569-73.

[63] Rubin K, Höök M, Öbrink B, Timpl R. Substrate adhesion of rat hepatocytes: Mechanism of attachment to collagen substrates. Cell 1981;24:463-70. doi:https://doi.org/10.1016/0092-8674(81)90337-8.

[64] Chu L, Tempelman LA, Miller C, Hammer DA. Centrifugation assay of Ig-E mediated cell adhesion to antigen coated gels. AIChE J 1994;40:692- 
703. doi:https://doi.org/10.1002/aic.690400412.

[65] McClay DR, Wessel GM, Marchase RB. Intercellular recognition: quantitation of initial binding events. Proc Natl Acad Sci U S A 1981;78:4975-9. doi:10.1073/pnas.78.8.4975.

[66] Lotz MM, Burdsal C, Erickson HP, McClay DR. Cell adhesion to fibronectin and tenascin: Quantitative measurements of initial binding and subsequent strengthening response. J Cell Biol 1989;109:1795-805. doi:10.1083/jcb.109.4.1795.

[67] Maheshwari G, Brown G, Lauffenburger D, Wells A, Griffith LG. Cell adhesion and motility depend on nanoscale RGD clustering. J Cell Sci 2000;113 ( Pt 1:1677-86.

[68] Angres B, Barth A, Nelson WJ. Mechanism for Transition from Initial to StableCell-Cell Adhesion: Kinetic Analysis of E-CadherinMediatedAdhesion Using a Quantitative Adhesion Assay. J Cell Biol 1996;134:549-57.

[69] Reyes CD, García AJ. A centrifugation cell adhesion assay for highthroughput screening of biomaterial surfaces. Wiley Period Inc J Biomed Mater Res 2003;67A:328-333.

[70] Thoumine O, Ott A, Louvard D. Critical centrifugal forces induce adhesion rupture or structural reorganization in cultured cells. Cell Motil Cytoskeleton 1996;33:276-87. doi:10.1002/(SICI)10970169(1996)33:4<276::AID-CM4>3.0.CO;2-7.

[71] Thoumine O, Ott A. Comparison of the mechanical properties of normal and transformed fibroblasts. Biorheology 1997;34:309-26. doi:10.3233/BIR-1997-344-505.

[72] Channavajjala LS, Eidsath A, Saxinger WC. A simple method for measurement of cell-substrate attachment forces: application to HIV-1 Tat. J Cell Sci 1997;110:249-56.

[73] Prakobphol A, Burdsal CA, Fisher SJ. Quantifying the Strength of Bacterial Adhesive Interactions with Salivary Glycoproteins. J Dent Res 1995;74:1212-8. doi:10.1177/00220345950740051101.

[74] Wertheim JA, Forsythe K, Druker BJ, Hammer D, Boettiger D, Pear WS. BCR-ABL - induced adhesion defects are tyrosine kinase - independent. Blood 2002;99:4122-31.

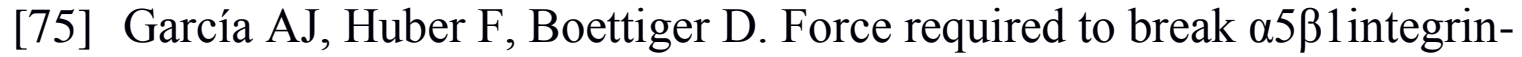


fibronectin bonds in intact adherent cells is sensitive to integrin activation state. J Biol Chem 1998;273:10988-93. doi:10.1074/jbc.273.18.10988.

[76] Shi Q, Boettiger D. A Novel Mode for Integrin-mediated Signaling: Tethering Is Required for Phosphorylation of FAK Y397. Mol Biol Cell 2003;14:4306-15. doi:10.1091/mbc.E03.

[77] Gallant ND, Capadona JR, Frazier AB, Collard DM, García AJ. Micropatterned surfaces to engineer focal adhesions for analysis of cell adhesion strengthening. Langmuir 2002;18:5579-84. doi:10.1021/la025554p.

[78] Bowen WR, Fenton AS, Lovitt RW, Wright CJ. The measurement of Bacillus mycoides spore adhesion using atomic force microscopy, simple counting methods, and a spinning disk technique. Biotechnol Bioeng 2002;79:170-9. doi:10.1002/bit.10321.

[79] Goldstein AS, DiMilla PA. Application of fluid mechanic and kinetic models to characterize mammalian cell detachment in a radial-flow chamber. Biotechnol Bioeng 1997;55:616-29. doi:10.1002/(SICI)10970290(19970820)55:4<616::AID-BIT4>3.0.CO;2-K.

[80] Dimilla PA, Stone JA, Quinn JA, Albelda SM, Lauffenburger AD. Maximal migration of human smooth muscle cells on fibronectin and type IV collagen occurs at an intermediate attachment strength. J Cell Biol 1993;122:729-37.

[81] Goldstein AS, DiMilla PA. Comparison of converging and diverging radial flow for measuring cell adhesion. AIChE J 1998;44:465-73. doi:10.1002/aic.690440222.

[82] Bearinger JP, Castner DG, Golledge SL, Rezania A, Hubchak S, Healy KE. P(AAm- co -EG) Interpenetrating Polymer Networks Grafted to Oxide Surfaces: Surface Characterization, Protein Adsorption, and Cell Detachment Studies. Langmuir 1997;13:5175-83. doi:10.1021/la970101j.

[83] Goldstein AS, DiMilla PA. Examination of membrane rupture as a mechanism for mammalian cell detachment from fibronectin-coated biomaterials. J Biomed Mater Res A 2003;67A:658-66. doi:10.1002/jbm.a.10125.

[84] Van Kooten TG, Schakenraad JM, Van der Mei HC, Busscher HJ. Development and use of a parallel-plate flow chamber for studying cellular adhesion to solid surfaces. J Biomed Mater Res 1992;26:725-38. doi: $10.1002 / \mathrm{jbm} .820260604$. 
[85] Weiss L. The measurement of cell adhesion. Exp Cell Res 1961;Suppl 8:141-53.

[86] Goldstein AS, Dimilla PA. Effect of adsorbed fibronectin concentration on cell adhesion and deformation under shear on hydrophobic surfaces. J Biomed Mater Res 2002;59:665-75. doi:10.1002/jbm.1276.

[87] Baumgartner JN, Yang CZ, Cooper SL. Physical property analysis and bacterial adhesion on a series of phosphonated polyurethanes. Biomaterials 1997;18:831-7. doi:10.1016/S0142-9612(96)00197-4.

[88] Van Kooten TG, Schakenraad JM, Van der Mei HC, Dekker A, Kirkpatrick CJ, Busscher HJ. Fluid shear induced endothelial cell detachment from glass - influence of adhesion time and shear stress. Med Eng Phys 1994;16:506-12. doi:10.1016/1350-4533(94)90077-9.

[89] Van Kooten TG, Schakenraad JM, Van der Mei HC, Busscher HJ. Influence of substratum wettability on the strength of adhesion of human fibroblasts. Biomaterials 1992;13:897-904. doi:10.1016/01429612(92)90112-2.

[90] Lee J, Lee S, Khang G, Lee H. The Effect of Fluid Shear Stress on Endothelial Cell Adhesiveness to Polymer Surfaces with Wettability Gradient. J Colloid Interface Sci 2000;230:84-90. doi:10.1006/jcis.2000.7080.

[91] Martines E, McGhee K, Wilkinson C, Curtis A. A Parallel-plate flow chamber to study initial cell adhesion on a nanofeatured surface. IEEE Trans Nanobioscience 2004;3:90-5. doi:10.1109/TNB.2004.828268.

[92] Truskey GA, Proulx TL. Relationship between 3 T3 cell spreading and the strength of adhesion on glass and silane surfaces. Biomaterials 1993;14:243-54. doi:10.1016/0142-9612(93)90114-H.

[93] Kapur R, Rudolph S. Cellular and cytoskeleton morphology and strength of adhesion of cells on self-assembled monolayers of organosilanes. Exp Cell Res 1998;244:275-85. doi:10.1006/excr.1998.4156.

[94] Messer RLW, Davis CM, Lewis JB, Adams Y, Wataha JC. Attachment of human epithelial cells and periodontal ligament fibroblasts to tooth dentin. J Biomed Mater Res - Part A 2006;79A:16-22. doi:10.1002/jbm.a.30703.

[95] Bakker DP, Van der Plaats A, Verkerke GJ, Busscher HJ, Van der Mei HC. Comparison of Velocity Profiles for Different Flow Chamber Designs Used in Studies of Microbial Adhesion to Surfaces. Appl Environ 
Microbiol 2003;69:6280-7. doi:10.1128/AEM.69.10.6280-6287.2003.

[96] Roosjen A, Kaper HJ, van der Mei HC, Norde W, Busscher HJ. Inhibition of adhesion of yeasts and bacteria by poly(ethylene oxide)-brushes on glass in a parallel plate flow chamber. Microbiology 2003;149:3239-46. doi:10.1099/mic.0.26519-0.

[97] McClaine JW, Ford RM. Characterizing the adhesion of motile and nonmotile Escherichia coli to a glass surface using a parallel-plate flow chamber. Biotechnol Bioeng 2002;78:179-89. doi:10.1002/bit.10192.

[98] Schmolke H, Demming S, Edlich A, Magdanz V, Büttgenbach S, FrancoLara E, et al. Polyelectrolyte multilayer surface functionalization of poly(dimethylsiloxane) (PDMS) for reduction of yeast cell adhesion in microfluidic devices. Biomicrofluidics 2010;4:044113. doi:10.1063/1.3523059.

[99] Gervais T, El-Ali J, Günther A, Jensen KF. Flow-induced deformation of shallow microfluidic channels. Lab Chip 2006;6:500-7. doi:10.1039/b513524a.

[100] Lu H, Koo LY, Wang WM, Lauffenburger DA, Griffith LG, Jensen KF. Microfluidic shear devices for quantitative analysis of cell adhesion. Anal Chem 2004;76:5257-64. doi:10.1021/ac049837t.

[101] Young EWK, Wheeler AR, Simmons CA. Matrix-dependent adhesion of vascular and valvular endothelial cells in microfluidic channels. Lab Chip 2007;7:1759-66. doi:10.1039/b712486d.

[102] Kwon KW, Choi SS, Lee SH, Kim B, Lee SN, Park MC, et al. Label-free, microfluidic separation and enrichment of human breast cancer cells by adhesion difference. Lab Chip 2007;7:1461-8. doi:10.1039/b710054j.

[103] Choi JW, Rosset S, Niklaus M, Adleman JR, Shea H, Psaltis D. 3Dimensional Electrode Patterning Within a Microfluidic Channel Using Metal Ion Implantation. Lab Chip 2010;10:783-8. doi:10.1039/b917719a.

[104] Mitchison JM, Swann MM. The mechanical properties of the cell surface. J Exp Biol 1954;31:443-60.

[105] Rand RP, Burton AC. Mechanical Properties of the Red Cell Membrane. I. Membrane Stiffness and Intracellular Pressure. Biophys J 1964;4:115-35. doi:10.1016/S0006-3495(64)86773-4.

[106] Chiou PY, Ohta AT, Wu MC. Massively parallel manipulation of single cells and microparticles using optical images. Nat Lett 2005;436:370-2. 
doi:10.1038/nature03831.

[107] Shao JY, Hochmuth RM. Micropipette suction for measuring piconewton forces of adhesion and tether formation from neutrophil membranes. Biophys J 1996;71:2892-901. doi:10.1016/S0006-3495(96)79486-9.

[108] Shao J-Y, Xu J. A modified micropipette aspiration technique and its application to tether formation from human neutrophils. J Biomech Eng 2002;124:388-96. doi:10.1115/1.1486469.

[109] Sung KL, Frojmovic MM, O’Toole TE, Zhu C, Ginsberg MH, Chien S. Determination of adhesion force between single cell pairs generated by activated GpIIb-IIIa receptors. Blood 1993;81:419-23.

[110]Zhao H, Dong X, Wang X, Li X, Zhuang F, Stoltz JF, et al. Studies on single-cell adhesion probability between lymphocytes and endothelial cells with micropipette technique. Microvasc Res 2002;63:218-26. doi:10.1006/mvre.2001.2390.

[111]Evans E, Ritchie K, Merkel R. Sensitive force technique to probe molecular adhesion and structural linkages at biological interfaces. Biophys J 1995:2580-7. doi:10.1016/S0006-3495(95)80441-8.

[112] Merkel R, Nassoy P, Leung A, Ritchie K, Evans E. Energy landscapes of receptor-ligand bonds explored with dynamic force spectroscopy. Nature 1999;397:50-3. doi:10.1038/16219.

[113] Evans E, Ritchie K. Dynamic strength of molecular adhesion bonds. Biophys J 1997;72:1541-55. doi:10.1016/S0006-3495(97)78802-7.

[114] Evans E. Looking inside molecular bonds at biological interfaces with dynamic force spectroscopy. Biophys Chem 1999;82:83-97. doi:10.1016/S0301-4622(99)00108-8.

[115] Evans E, Ritchie K. Strength of a weak bond connecting flexible polymer chains. Biophys J 1999;76:2439-47. doi:10.1016/S0006-3495(99)77399-6.

[116] Evans E, Ludwig F. Dynamic strengths of molecular anchoring and material cohesion in fluid biomembranes. J Phys Condens Matter 2000;12:A315-20. doi:10.1088/0953-8984/12/8A/341.

[117] Evans E, Leung A, Hammer D, Simon S. Chemically distinct transition states govern rapid dissociation of single L-selectin bonds under force. Proc Natl Acad Sci U S A 2001;98:3784-9. doi:10.1073/pnas.061324998.

[118] Evans E. Probing the relation between force-lifetime-and chemistry in 
single molecular bonds. Annu Rev Biophys Biomol Struct 2001;30:10528. doi:10.1146/annurev.biophys.30.1.105.

[119] Spillmann C, Osorio D, Waugh R. Integrin activation by divalent ions affects neutrophil homotypic adhesion. Ann Biomed Eng 2002;30:100211. doi:10.1114/1.1511241.

[120] Lomakina EB, Waugh RE. Micromechanical tests of adhesion dynamics between neutrophils and immobilized ICAM-1. Biophys J 2004;86:122333. doi:10.1016/S0006-3495(04)74196-X.

[121] Környei Z, Beke S, Mihálffy T, Jelitai M, Kovács KJ, Szabó Z, et al. Cell sorting in a Petri dish controlled by computer vision. Sci Rep 2013;3:1088. doi:10.1038/srep01088.

[122] Ungai-Salánki R, Gerecsei T, Fürjes P, Orgovan N, Sándor N, Holczer E, et al. Automated single cell isolation from suspension with computer vision. Sci Rep 2016;6:20375. doi:10.1038/srep20375.

[123] Salánki R, Gerecsei T, Orgovan N, Sándor N, Péter B, Bajtay Z, et al. Automated single cell sorting and deposition in submicroliter drops. Appl Phyisics Lett 2014;105:083703. doi:10.1063/1.4893922.

[124] Jani PK, Schwaner E, Kajdácsi E, Debreczeni ML, Ungai-Salánki R, Dobó $\mathrm{J}$, et al. Complement MASP-1 enhances adhesion between endothelial cells and neutrophils by up-regulating E-selectin expression. Mol Immunol 2016;75:38-47. doi:10.1016/j.molimm.2016.05.007.

[125] Orgovan N, Ungai-salánki R, Lukácsi S, Sándor N, Bajtay Z, Erdei A, et al. Adhesion kinetics of human primary monocytes, dendritic cells, and macrophages : Dynamic cell adhesion measurements with a label-free optical biosensor and their comparison with end-point assays Adhesion kinetics of human primary monocytes, dendritic c. Biointerphases 2016;031001. doi:1116/1.4954789.

[126] Sándor N, Lukácsi S, Ungai-Salánki R, Orgovan N, Erdei A, Bajtay Z. CD11c / CD18 Dominates Adhesion of Human Monocytes, Macrophages and Dendritic Cells over CD11b / CD18. PLoS One 2016;11:e0163120. doi:10.1371/journal.pone.0163120.

[127]Zhang H, Liu KK. Optical tweezers for single cells. J R Soc Interface 2008;5:671-90. doi:10.1098/rsif.2008.0052.

[128] Neuman KC, Chadd EH, Liou GF, Bergman K, Block SM. Characterization of photodamage to Escherichia coli in optical traps. 
Biophys J 1999;77:2856-63. doi:10.1016/S0006-3495(99)77117-1.

[129]Dai J, Sheetz MP. Mechanical properties of neuronal growth cone membranes studied by tether formation with laser optical tweezers. Biophys J 1995;68:988-96. doi:10.1016/S0006-3495(95)80274-2.

[130] Neuman KC, Nagy A. Single-molecule force spectroscopy: Optical tweezers, magnetic tweezers and atomic force microscopy. Nat Methods 2008;5:491-505. doi:10.1038/nmeth.1218.

[131] Dholakia K, Reece P. Optical micromanipulation takes hold. Nano Today 2006;1:18-27. doi:10.1016/S1748-0132(06)70019-6.

[132] Jähnke T, Rauch P. Optical tweezers for single-cell, multicellular investigations in the life sciences. Am Lab 2015.

[133] Hénon S, Lenormand G, Richert A, Gallet F. A new determination of the shear modulus of the human erythrocyte membrane using optical tweezers. Biophys J 1999;76:1145-51. doi:10.1016/S0006-3495(99)77279-6.

[134] König K, Liang H, Berns MW, Tromberg BJ. Cell damage in near-infrared multimode optical traps as a result of multiphoton absorption. Opt Lett 1996;21:1090-2. doi:10.1364/ol.21.001090.

[135] Korda PT, Spalding GC, Grier DG. Evolution of a colloidal critical state in an optical pinning potential landscape. Phys Rev B 2002;66:024504. doi:10.1103/PhysRevB.66.024504.

[136] Gross SP. Application of optical traps in vivo. Methods Enzymol 2003;361:162-74. doi:10.1016/S0076-6879(03)61010-4.

[137] Pavone FS, Antolini R, Sacconi L, Tolić-Nørrelykke IM, Stringari C. Optical micromanipulations inside yeast cells. Appl Opt 2005;44:2001-7. doi:10.1364/ao.44.002001.

[138] Castelain M, Pignon F, Piau JM, Magnin A, Mercier-Bonin M, Schmitz P. Removal forces and adhesion properties of Saccharomyces cerevisiae on glass substrates probed by optical tweezer. J Chem Phys 2007;127:135104. doi:10.1063/1.2772270.

[139] Castelain M, Rouxhet PG, Pignon F, Magnin A, Piau JM. Single-cell adhesion probed in-situ using optical tweezers: A case study with Saccharomyces cerevisiae. J Appl Phys 2012;111:114701. doi:10.1063/1.4723566.

[140] Castelain M, Pignon F, Piau JM, Magnin A. The initial single yeast cell 
adhesion on glass via optical trapping and Derjaguin-Landau-VerweyOverbeek predictions. J Chem Phys 2008;128:135101. doi:10.1063/1.2842078.

[141] Kim ST, Shin Y, Brazin K, Mallis RJ, Sun ZYJ, Wagner G, et al. TCR mechanobiology: Torques and tunable structures linked to early $\mathrm{T}$ cell signaling. Front Immunol 2012;3:1-8. doi:10.3389/fimmu.2012.00076.

[142] Block SM, Goldstein LSB, Schnapp BJ. Bead movement by single kinesin molecules studied with optical tweezers. Nature 1990;348:348-52.

[143] Litvinov RI, Shuman H, Bennett JS, Weisel JW, Litvinov R, Shumant H, et al. Binding strength and activati on state of single fibrinogen-integrin pairs on I iving cells. PNAS 2002;99:7426-31.

[144] Thoumine O, Kocian P, Kottelat A, Meister JJ. Short-term binding of fibroblasts to fibronectin: Optical tweezers experiments and probabilistic analysis. Eur Biophys J 2000;29:398-408. doi:10.1007/s002490000087.

[145] W. H, B. A, J.H. T, R.G. L, K.A. A. Temporal effects of cell adhesion on mechanical characteristics of the single chondrocyte. J Orthop Res 2003;21:88-95.

[146] Li Z, Anvari B, Takashima M, Brecht P, Torres JH, Brownell WE. Membrane tether formation from outer hair cells with optical tweezers. Biophys J 2002;82:1386-95. doi:10.1016/S0006-3495(02)75493-3.

[147] Binnig G, Quate CF. Atomic Force Microscope. Phys Rev Lett 1986;56:930-3. doi:10.1103/PhysRevLett.56.930.

[148] Hinterdorfer P, Dufrêne YF. Detection and localization of single molecular recognition events using atomic force microscopy. Nat Methods 2006;3:347-55. doi:10.1038/nmeth871.

[149] Friedrichs J, Helenius J, Muller DJ. Quantifying cellular adhesion to extracellular matrix components by single-cell force spectroscopy. Nat Protoc 2010;5:1353-61. doi:10.1038/nprot.2010.89.

[150] Alsteens D, Gaub HE, Newton R, Pfreundschuh M, Gerber C, Müller DJ. Atomic force microscopy-based characterization and design of biointerfaces. Nat Rev Mater 2017;2:17008 1-16. doi:10.1038/natrevmats.2017.8.

[151] Hugel T, Seitz M. The Study of Molecular Interactions by AFM Force Spectroscopy. Macromol Rapid Commun 2001;22:989-1016. 
[152] Dufrêne YF, Evans E, Engel A, Helenius J, Gaub HE, Müller DJ. Five challenges to bringing single-molecule force spectroscopy into living cells. Nat Methods 2011;8:123-7. doi:10.1038/nmeth0211-123.

[153] Moy VT, Florin E, Gaub HE. Intermolecular Forces and. Science (80- ) 1994;266:257-60.

[154] Friedrichs J, Legate KR, Schubert R, Bharadwaj M, Werner C, Müller DJ, et al. A practical guide to quantify cell adhesion using single-cell force spectroscopy. Methods 2013;60:169-78. doi:10.1016/j.ymeth.2013.01.006.

[155] Benoit M, Gabriel D, Gerisch G, Gaub HE. Discrete interactions in cell adhesion measured by single-molecule force spectroscopy. Nat Cell Biol 2000;2:313-7. doi:10.1038/35014000.

[156] Li F, Redick SD, Erickson HP, Moy VT. Force measurements of the alpha5beta1 integrin-fibronectin interaction. Biophys J 2003;84:1252-62. doi:10.1016/S0006-3495(03)74940-6.

[157] Lower SK, Hochella MF, Beveridge TJ. Bacterial recognition of mineral surfaces: nanoscale interactions between Shewanella and alpha-FeOOH. Science 2001;292:1360-3. doi:10.1126/science.1059567.

[158] Bowen W, Lovitt RW, Wright C. Atomic Force Microscopy Study of the Adhesion of Saccharomyces cerevisiae. J Colloid Interface Sci 2001;237:54-61. doi:10.1006/jcis.2001.7437.

[159] Razatos A, Ong Y, Sharma M GG. Molecular determinants of bacterial adhesion monitored by atomic force microscopy. Proc Natl Acad Sci U S A 1998;95:11059-64. doi:10.1073/pnas.95.19.11059.

[160] Guillaume-Gentil O, Potthoff E, Ossola D, Franz CM, Zambelli T, Vorholt JA. Force-controlled manipulation of single cells: From AFM to FluidFM. Trends Biotechnol 2014;32:381-8. doi:10.1016/j.tibtech.2014.04.008.

[161] Benoit M, Gaub HE. Measuring cell adhesion forces with the atomic force microscope at the molecular level. Cells Tissues Organs 2002;172:174-89. doi:10.1159/000066964.

[162] Fotiadis D, Scheuring S, Müller S, Engel A, Müller DJ. Imaging and manipulation of biological structures with the AFM. Micron 2002;33:38597. doi:10.1016/S0968-4328(01)00026-9.

[163] Weisenhorn L, Hansma PK, Albrecht TR, Quate CF. Forces in atomic force microscopy in air and water. Appl Phys Lett 1989;54:2651-3. 
[164] Müller D, Büldt G, Engel A. Force-induced conformational change of bacteriorhodopsin. J Mol Biol 1995;249:239-43.

doi:10.1006/jmbi.1995.0292.

[165] Müller DJ, Schabert F, Büldt G, Engel A. Imaging purple membranes in aqueous solutions at sub-nanometer resolution by atomic force microscopy. Biophys J 1995;68:1681-6. doi:10.1016/S00063495(95)80345-0.

[166] Hansma HG, Vesenka J, Siegerist C, Kelderman G, Morrett H, Sinsheimer $\mathrm{RL}$, et al. Reproducible imaging and dissection of plasmid DNA under liquid with the atomic force microscope. Science (80- ) 1992;256:1180-4. doi:10.1126/science.256.5060.1180.

[167] Müller DJ, Schoenenberger CA, Büldt G, Engel A. Immuno-atomic force microscopy of purple membrane. Biophys J 1996;70:1796-802. doi:10.1016/S0006-3495(96)79743-6.

[168] Taubenberger A, Cisneros DA, Friedrichs J, Puech P-H, Muller DJ, Franz CM. Revealing Early Steps of $\alpha 2 \beta 1$ Integrin-mediated Adhesion to Collagen Type I by Using Single-Cell Force Spectroscopy. Mol Biol Cell 2007;18:1634-44. doi:10.1091/mbc.E06.

[169] Dettmann W, Grandbois M, André S, Benoit M, Wehle AK, Kaltner H, et al. Differences in zero-force and force-driven kinetics of ligand dissociation from $\beta$-galactoside-specific proteins (plant and animal lectins, immunoglobulin G) monitored by plasmon resonance and dynamic single molecule force microscopy. Arch Biochem Biophys 2000;383:157-70. doi:10.1006/abbi.2000.1993.

[170] Müller DJ, Engel A. Voltage and pH - induced channel closure of porin OmpF visualized by atomic force microscopy. J Mol Biol Vol 1999;285:1347-51. doi:https://doi.org/10.1006/jmbi.1998.2359.

[171] Drake B, Prater CB, Weisenhorn a L, Gould S a, Albrecht TR, Quate CF, et al. Imaging crystals, polymers, and processes in water with the atomic force microscope. Science 1989;243:1586-9.

doi:10.1126/science.2928794.

[172] Mou J, Yang J, Shao Z. Atomic force microscopy of cholera toxin Boligomers bound to bilayers of biologically relevant lipids. J Mol Biol 1995;248:507-12. doi:10.1006/jmbi.1995.0238.

[173] Müller DJ, Baumeister W, Engel A. Conformational change of the hexagonally packed intermediate layer of Deinococcus radiodurans 
monitored by atomic force microscopy. J Bacteriol 1996;178:3025-30.

[174] Friedrichs J, Helenius J, Müller DJ. Stimulated single-cell force spectroscopy to quantify cell adhesion receptor crosstalk. Proteomics 2010;10:1455-62. doi:10.1002/pmic.200900724.

[175] Beaussart A, Herman P, El-Kirat-Chatel S, Lipke PN, Kucharíková S, Van Dijck P, et al. Single-cell force spectroscopy of the medically important Staphylococcus epidermidis-Candida albicans interaction. Nanoscale 2013;5:10.1039/c3nr03272h. doi:10.1039/c3nr03272h.

[176] Sénéchal A, Carrigan SD, Tabrizian M. Probing surface adhesion forces of enterococcus faecalis to medical-grade polymers using atomic force microscopy. Langmuir 2004;20:4172-7. doi:10.1021/la035847y.

[177] Chang K-C, Hammer DA. Influence of Direction and Type of Applied Force on the Detachment of Macromolecularly-Bound Particles from Surfaces. Langmuir 1996;12:2271-82. doi:10.1021/la950690y.

[178] Busscher HJ, Poortinga AT, Bos R. Lateral and perpendicular interaction forces involved in mobile and immobile adhesion of microorganisms on model solid surfaces. Curr Microbiol 1998;37:319-23. doi:10.1007/s002849900385.

[179] Parpura V, Haydon PG, Sakaguchi DS, Henderson E. Atomic force microscopy and manipulation of living glial cells. J Vac Technol A 1993;11:773-5. doi:10.1116/1.578346.

[180] Sagvolden G, Giaever I, Feder J. Characteristic Protein Adhesion Forces on Glass and Polystyrene Substrates by Atomic Force Microscopy. Langmuir 1998;14:5984-7. doi:10.1021/la980271b.

[181] Meister A, Gabi M, Behr P, Studer P, Vörös J, Niedermann P, et al. FluidFM: Combining atomic force microscopy and nanofluidics in a universal liquid delivery system for single cell applications and beyond. Nano Lett 2009;9:2501-7. doi:10.1021/n1901384x.

[182] Saftics A, Türk B, Sulyok A, Nagy N, Szekacs I, Horvath R, et al. Biomimetic dextran-based hydrogel layers for cell micropatterning over large areas using the FluidFM BOT technology. Langmuir 2019. doi:10.1021/acs.langmuir.8b03249.

[183] Dörig P, Stiefel P, Behr P, Sarajlic E, Bijl D, Gabi M, et al. Forcecontrolled spatial manipulation of viable mammalian cells and microorganisms by means of FluidFM technology. Appl Phys Lett 
2010;97:023701. doi:https://doi.org/10.1063/1.3462979.

[184] Potthoff E, Ossola D, Zambelli T, Vorholt JA. Bacterial adhesion force quantification by fluidic force microscopy. Nanoscale 2014;00:1-3. doi:10.1039/c4nr06495j.

[185] Amarouch MY, El Hilaly J, Mazouzi D. AFM and FluidFM Technologies: Recent Applications in Molecular and Cellular Biology. Scanning 2018;2018:1-10. doi:10.1155/2018/7801274.

[186] Grüter RR, Vörös J, Zambelli T. FluidFM as a lithography tool in liquid: Spatially controlled deposition of fluorescent nanoparticles. Nanoscale 2013;5:1097-104. doi:10.1039/c2nr33214k.

[187] Hirt L, Ihle S, Pan Z, Dorwling-Carter L, Reiser A, Wheeler JM, et al. Template-Free 3D Microprinting of Metals Using a Force-Controlled Nanopipette for Layer-by-Layer Electrodeposition. Adv Mater 2016;28:2311-5. doi:10.1002/adma.201504967.

[188] Ventrici De Souza J, Liu Y, Wang S, Dörig P, Kuhl TL, Frommer J, et al. Three-Dimensional Nanoprinting via Direct Delivery. J Phys Chem B 2018;122:956-62. doi:10.1021/acs.jpcb.7b06978.

[189] Wang JH, Li B. The principles and biological applications of cell traction force microscopy. Microsc Sci Technol Appl Educ 2010;29:449-58.

[190] Sabass B, Gardel ML, Waterman CM, Schwarz US. High resolution traction force microscopy based on experimental and computational advances. Biophys J 2008;94:207-20. doi:10.1529/biophysj.107.113670.

[191] Schwarz US, Balaban NQ, Riveline D, Bershadsky A, Geiger B, Safran SA. Calculation of forces at focal adhesions from elastic substrate data: The effect of localized force and the need for regularization. Biophys $\mathbf{J}$ 2002;83:1380-94. doi:10.1016/S0006-3495(02)73909-X.

[192] Hur SS, Zhao Y, Li YS, Botvinick E, Chien S. Live Cells Exert 3Dimensional Traction Forces on Their Substrata. Cell Mol Bioeng 2009;2:425-36. doi:10.1007/s12195-009-0082-6.

[193] Wang JHC, Lin JS. Cell traction force and measurement methods. Biomechan Model Mechanobiol 2007;6:361-71. doi:10.1007/s10237-0060068-4.

[194] Ladoux B, Nicolas A. Physically based principles of cell adhesion mechanosensitivity in tissues. Reports Prog Phys 2012;75:116601. doi:10.1088/0034-4885/75/11/116601. 
[195] Colin-York H, Eggeling C, Fritzsche M. Dissection of mechanical force in living cells by super-resolved traction force microscopy. Nat Protoc 2017;12:783-96. doi:10.1038/nprot.2017.009.

[196] Hall MS, Long R, Feng X, Huang Y, Hui CY, Wu M. Toward single cell traction microscopy within 3D collagen matrices. Exp Cell Res 2013;319:2396-408. doi:10.1016/j.yexcr.2013.06.009.

[197] Steinwachs J, Metzner C, Skodzek K, Lang N, Thievessen I, Mark C, et al. Three-dimensional force microscopy of cells in biopolymer networks. Nat Methods 2016;13:171-6. doi:10.1038/nmeth.3685.

[198] Yang Z. Validation of the Boussinesq equation for use in traction field determination. Comput Methods Biomech Biomed Engin 2011;14:106570. doi:10.1080/10255842.2010.506642.

[199] Yang Z, Lin JS, Chen J, Wang JHC. Determining substrate displacement and cell traction fields-a new approach. J Theor Biol 2006;242:607-16. doi:10.1016/j.jtbi.2006.05.005.

[200] Krishnan R, Park CY, Lin YC, Mead J, Jaspers RT, Trepat X, et al. Reinforcement versus fluidization in cytoskeletal mechanoresponsiveness. PLoS One 2009;4:e5486. doi:10.1371/journal.pone.0005486.

[201] Li B, Li F, Puskar KM, Wang JHC. Spatial patterning of cell proliferation and differentiation depends on mechanical stress magnitude. J Biomech 2009;42:1622-7. doi:10.1016/j.jbiomech.2009.04.033.

[202] Chen J, Li H, SundarRaj N, Wang JHC. Alpha-smooth muscle actin expression enhances cell traction force. Cell Motil Cytoskeleton 2007;64:248-57. doi:10.1002/cm.20178.

[203] Gov NS. Traction forces during collective cell motion. HFSP J 2009;3:223-7. doi:10.2976/1.3185785.

[204] Ladoux B. Cells guided on their journey. Nat Phys 2009;5:377-8. doi:10.1038/nphys1281.

[205] Lakowicz JT. Principles of fluorescence spectroscopy. 3rd ed. 2006.

[206] Clapp AR, Medintz IL, Mauro JM, Fisher BR, Bawendi MG, Mattoussi H. Fluorescence Resonance Energy Transfer between Quantum Dot Donors and Dye-Labeled Protein Acceptors. J Am Chem Soc 2004;126:301-10. doi:10.1021/ja037088b.

[207] Weiss S. Fluorescence spectroscopy of single biomolecules. Science (80- ) 
1999;283:1676-83. doi:DOI: 10.1126/science.283.5408.1676.

[208] Stryer L, Hauglnd RP. Energy transfer: A spectroscopic ruler. Proc NAS 1967;58:719-26. doi:10.1146/annurev.bi.47.070178.004131.

[209] Kong HJ, Polte TR, Alsberg E, Mooney DJ. FRET measurements of celltraction forces and nano-scale clustering of adhesion ligands varied by substrate stiffness. Proc Natl Acad Sci 2005;102:4300-5. doi:10.1073/pnas.0405873102.

[210]Freikamp A, Mehlich A, Klingner C, Grashoff C. Investigating piconewton forces in cells by FRET-based molecular force microscopy. $\mathrm{J}$ Struct Biol 2017;197:37-42. doi:10.1016/j.jsb.2016.03.011.

[211] Cost AL, Ringer P, Chrostek-Grashoff A, Grashoff C. How to Measure Molecular Forces in Cells: A Guide to Evaluating Genetically-Encoded FRET-Based Tension Sensors. Cell Mol Bioeng 2015;8:96-105. doi:10.1007/s12195-014-0368-1.

[212] Jurchenko C, Salaita KS. Lighting Up the Force: Investigating Mechanisms of Mechanotransduction Using Fluorescent Tension Probes. Mol Cell Biol 2015;35:2570-82. doi:10.1128/MCB.00195-15.

[213] Chang C-W, Kumar S. Vinculin tension distributions of individual stress fibers within cell-matrix adhesions. J Cell Sci 2013;126:3021-30. doi:10.1242/jcs.119032.

[214] Borghi N, Sorokina M, Shcherbakova OG, Weis WI, Pruitt BL, Nelson WJ, et al. E-cadherin is under constitutive actomyosin-generated tension that is increased at cell-cell contacts upon externally applied stretch. Proc Natl Acad Sci 2012;109:12568-73. doi:10.1073/pnas.1204390109.

[215] Cai D, Chen SC, Prasad M, He L, Wang X, Choesmel-Cadamuro V, et al. Mechanical feedback through E-cadherin promotes direction sensing during collective cell migration. Cell 2014;157:1146-59.

doi:10.1016/j.cell.2014.03.045.

[216] Conway DE, Breckenridge MT, Hinde E, Gratton E, Chen CS, Schwartz MA. Fluid shear stress on endothelial cells modulates mechanical tension across VE-cadherin and PECAM-1. Curr Biol 2013;23:1024-30. doi:10.1016/j.cub.2013.04.049.

[217] Kelley M, Yochem J, Krieg M, Calixto A, Heiman MG, Kuzmanov A, et al. FBN-1, a fibrillin-related protein, is required for resistance ofthe epidermis to mechanical deformation during c. Elegans embryogenesis. 
Elife 2015:1-30. doi:10.7554/eLife.06565.

[218] Morimatsu M, Mekhdjian AH, Adhikari AS, Dunn AR. Molecular tension sensors report forces generated by single integrin molecules in living cells. Nano Lett 2013;13:3985-9. doi:10.1021/n14005145.

[219] Huebsch ND, Mooney DJ. Fluorescent resonance energy transfer: A tool for probing molecular cell-biomaterial interactions in three dimensions. Biomaterials 2007;28:2424-37. doi:10.1016/j.biomaterials.2007.01.023.

[220] Rahul R, Sungchul H, Taekjip H. A Practical Guide to Single Molecule FRET. Nat Methods 2013;5:507-16. doi:10.1038/nmeth.1208.A.

[221] Johnson AE. Fluorescence approaches for determining protein conformations, interactions and mechanisms at membranes. Traffic 2005;6:1078-92. doi:10.1111/j.1600-0854.2005.00340.x.

[222] Dobrucki JW, Kubitscheck U. Fluorescence Microscopy. Fluoresc Microsc 2005;2:910-9. doi:10.1002/9783527687732.ch3.

[223] Kirchner J, Kam Z, Tzur G, Bershadsky AD, Geiger B. Live-cell monitoring of tyrosine phosphorylation in focal adhesions following microtubule disruption. J Cell Sci 2002;116:975-86. doi: $10.1242 /$ jes.00284.

[224] Kong HJ, Boontheekul T, Mooney DJ. Quantifying the relation between adhesion ligand-receptor bond formation and cell phenotype. Proc Natl Acad Sci 2006;103:18534-9. doi:10.1073/pnas.0605960103.

[225] Yamada S, Nelson WJ. Localized zones of Rho and Rac activities drive initiation and expansion of epithelial cell-cell adhesion. J Cell Biol 2007;178:517-27. doi:10.1083/jcb.200701058.

[226] Svoboda K, Block SM. Force and velocity measured for single kinesin molecules. Cell 1994;77:773-84. doi:10.1016/0092-8674(94)90060-4. 